Please do not destroy or throw away this publication. If you have no further use for it, write to the Geological Survey at Washington and ask for a frank to return it

UNITED STATES DEPARTMENT OF THE INTERIOR

Harold L. Ickes, Secretary

GEOLOGICAL SURVEY

W. C. Mendenhall, Director

Professional Paper 175-A

\title{
MIOCENE FORAMINIFERA OF THE GOASTAL PLAIN OF THE EASTERN UNITED STATES
}

BY

JOSEPH AUGUSTINE CUSHMAN

AND

EDGAR D. CAHILL

Shorter contributions to general geology, 1932-33

(Pages 1-50)

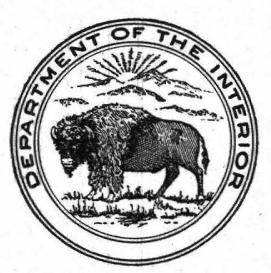

UNITED STATES

GOVERNMENT PRINTING OFFICE

WASHINGTON : 1933

For sale by the Superintendent of Documents, Washington, D.C. - - - - - Price 15 cents 


\section{CONTENTS}

Abstract.

Introduction

Localities of foraminiferal material

Choctawhatchee formation of Florida

Duplin marl, South Carolina

Duplin marl, North Carolina

Yorktown formation, North Carolina

Yorktown formation, Virginia

St. Marys formation, Virginia _

Calvert formation, Maryland _

Choptank formation, Maryland _

St. Marys formation, Maryland

Section of Calvert formation at Chesapeake Beach, Md Descriptions of species.

\section{ILLUSTRATIONS}

Plates 1-13. Miocene Foraminifera of the Atlantic Coastal Plain

\section{INSERT}

Distribution of Foraminifera of the Miocene of the Atlantic Coastal Plain 


\title{
SHORTER CONTRIBUTIONS TO GENERAL GEOLOGY, 1932-33
}

\author{
MIOCENE FORAMINIFERA OF THE COASTAL PLAIN OF THE EASTERN UNITED STATES
}

\author{
By Joseph Augustine Cushman and Edgar D. Cahill
}

\begin{abstract}
In this paper 134 species or varieties of Foraminifera from the Chesapeake group of Maryland and Virginia, the Duplin marl of the Carolinas, and the Choctawhatchee formation of Florida are described and figured. Of these, 2 species or varieties are first known from the Jurassic, 7 from the Upper Cretaceous, 15 from the Eocene, 11 from the Oligocene, 4 extend into the Pliocene, 1 into the Pleistocene, and 79 are still living. The following species are described as new:

Millettella spinata.

Urnulina rotundata.

Massilina marylandica.
\end{abstract}

\section{INTRODUCTION}

In the following report the species of Foraminifera found in the Miocene of the Coastal Plain region of the eastern United States from Florida to Maryland are described and recorded. Numerous papers have been published on this region, some of which, however, are largely lists. Where the original material on which a paper was based has not been available for the present study, the records have been omitted, as it is very difficult to place the species in their proper position without seeing the actual specimens.

In a previous paper ${ }^{1}$ the senior author has recorded and figured much Miocene material from this same general region. In a more recently published paper ${ }^{2}$ the Miocene Foraminifera of the Choctawhatchee formation of Florida were described and figured. The subject matter of that paper has been used here, and all the specimens which were available for study have again been gone over. Through the courtesy of Mr. Herman Gunter, State geologist of Florida, it has been possible to use a part of the original figures that were drawn for the Florida report. These have been used to illustrate species which are either confined to Florida or are not well represented by good specimens for illustration in the collections northward from Florida. The other illustrations have been drawn directly from material from the more northern States. Much new material from North Carolina, Virginia, and Maryland has been available for the present studies. A list of all these stations may be found on a later page.

1 Cushman, J. A., Some Pliocene and Miocene Foraminifera of the Coastal Plain of the United States: U. S. Geol. Survey Bull. 676, 1918.

2 Cushman, J. A., The Foraminifera of the Choctawhatchee formation of Florida: Florida Geol. Survey Bull. 4, 1930.

An attempt has been made to place the species described in Bulletin 676 in the present scheme of classification and to restudy those species in the light of later collections. The references under the different species, therefore, will serve to place those species recorded in the earlier report and make them consistent with the present classification and the present understanding of the limits of specific differentiation, which are more exact because of the very much greater amount of material now available for study.

While this paper was in proof Bulletin 9 of the Florida State Geological Survey appeared, on the Foraminifera of the upper, middle, and part of the lower Miocene of Florida. This bulletin deals with a wider range of Miocene material than is included in the present paper, which is confined to the Choctawhatchee as far as Florida is concerned. To bring this paper as nearly up to date as possible references to Bulletin 9 of the Florida Survey have been inserted under the species and notes added on the distribution of those species.

There are, however, a number of new records and new species in Bulletin 9, which are noted below, with references to page, plate, and figure, that these may be available to the reader of this paper.

Textularia candeiana D'Orbigny, p. 41, pl. 8, figs. 4a, b.

Textularia foliacea Heron-Allen and Earland var. occidentalis Cushman, p. 41, pl. 1, figs. 4, 5 .

Textularia warreni Cushman and Ellisor, p. 42, pl. 1, figs. 6a, b. Bigenerina floridana Cushman and Ponton, p. 42, pl. 1, figs. 9-12.

Clavulina tricarinata D'Orbigny, p. 43, pl. 1, figs. 13a, b.

Quinqueloculina candeiana D'Orbigny, p. 44, pl. 2, figs. 1a-c. Quinqueloculina costata D'Orbigny, p. 44, pl. 2, figs. 2, 3.

Quinqueloculina crassa D'Orbigny var. subcuneata Cushman, p. 45 , pl. 2 , figs. $5 \mathrm{a}-\mathrm{c}$.

Quinqueloculina chipolensis Cushman and Ponton, p. 45, pl. 3, figs. 1-3.

Massilina inaequalis Cushman, p. 46, pl. 3, figs. 4a-c.

Massilina bosciana (D’Orbigny), p. 46, pl. 3, figs. 5a-c.

Massilina quadrans Cushman and Ponton, p. 47, pl. 3, figs. 6-8.

Massilina gunteri Cushman and Ponton, p. 47, pl. 4, figs. 1a-c.

Massilina incisa Cushman and Ponton, p. 47, pl. 4, figs. 2-6. Massilina spinata Cushman and Ponton, p. 48, pl. 5, figs. 1-3. Massilina spinata Cushman and Ponton var. chipolensis Cushman and Ponton, p. 48, pl. 5, figs. 4-6.

Massilina spincita Cushman and Ponton var. glabrata Cushman and Ponton, p. 49, pl. 5, figs. 7a-c.

Spiroloculina grateloupi D’Orbigny, p. 49. 
Hauerina bradyi Cushman, p. 50, pl. 6, figs. 1a-c. Articulina sagra D'Orbigny var. miocenica Cushman and Ponton, p. 51, pl. 6, figs. 2-4.

Articulina mayori Cushman, p. 51, pl. 6, figs. 5a, b. Triloculina trigonula Lamarck, p. 52, pl. 6, figs. 6a-c. Triloculina oblonga (Montagu), p. 52, pl. 6, figs. 7a-c. Triloculina gracilis D’Orbigny, p. 53, pl. 6, figs. 8, 9. Triloculina quadrilateralis D'Orbigny, p. 53, pl. 7, figs. 1a-c. Triloculina quadrilateralis D'Orbigny var. longicostata Cushman and Ponton, p. 53, pl. 7, figs. 2a-c.

Triloculina rotunda D’Orbigny, p. 54, pl. 6, figs. 10a-c.

Triloculina brongniartii D'Orbigny, p. 54, pl. 6, figs. 11a-c.

Flintina floridana Cushman and Ponton, p. 55, pl. 7, figs. 3-6.

Pyrgo denticulata (H. B. Brady), p. 56, pl. 7, figs. 7, 8 .

Vertebralina cassis D'Orbigny, p. 57, pl. 8, figs. 1a, b.

Vertebralina multilocularis (H. B. Brady, Parker and Jones), p. 57 , pl. 8 , figs. 2,3 .

Robulus vaughani (Cushman), p. 59, pl. 8, figs. 5-10.

Marginulina glabra D'Orbigny (?), p. 59, pl. 8, figs. 12a, b.

Lingulina sp. (?), p. 60 , pl. 12, figs. $13 \mathrm{a}, \mathrm{b}$.

Nodosaria calomorpha Reuss, p. 61, pl. 9, fig. 7.

Nodosaria longiscata Reuss, p. 62.

Lagena marginata (Walker and Jacob), p. 63, pl. 8, fig. 13.

Lagena gracilis Williamson, p. 64, pl. 9, figs. 8, 9.

Lagena quadrata (Williamson), p. 64, pl. 12, figs. 17, 18.

Guttulina lactea (Walker and Jacob), p. 65, pl. 9, figs 15a, b. Guttulina caudata D'Orbigny, p. 65, pl. 9, figs. 16, 17.

Guttulina roemeri (Reuss), p. 66.

Globulina inaequalis Reuss var. caribaea D'Orbigny, p. 66, pl. 10, fig. 2.

Polymorphina advena Cushman, p. 67, pl. 10, fig. 4.

Sigmomorphina pearceyi Cushman and Ozawa, p. 67, pl. 10,

figs. $5 \mathrm{a}, \mathrm{b}$.

Sigmomorphina undulosa (Terquem), p. 68, pl. 10, figs. 6a-c. Elphidium fimbriatulum (Cushman), p. 70, pl. 11, figs. 2a, b. Elphidium chipolensis (Cushman), p. 70, pl. 11, figs. 3a, b. Peneroplis proteus D'Orbigny, p. 71, pl. 10, figs. 7-11, 14. Peneroplis bradyi Cushman, p. 72, pl. 10, figs. 12, 13.

Sorites (?) sp. (?), p. 72, pl. 17, figs. 1-8.

Pavonina miocenica Cushman and Ponton, p. 73, pl. 12, figs.

19a, b.

Amphimorphina sp. (?), p. 75, pl. 11, figs. 4-6.

Nodogenerina advena Cushman and Laiming, p. 75, pl. 11, fig. 10.

Buliminella subteres (H. B. Brady), p. 76, pl. 11, figs. 9a, b. Bulimina marginata D'Orbigny, p. 77, pl. 11, fig. 12. Bulimina buchiana D'Orbigny, p. 78, pl. 12, figs. 1a, b. Bulimina ovata D'Orbigny, p. 78, pl. 11, fig. 11.

Globobulimina pacifica Cushman, p. 79, pl. 12, fig. 2.

Virgulina pontoni Cushman, p. 80, pl. 12, figs. 10, 11.

Virgulina (Virgulinella) gunteri Cushman var. curtata Cushman and Ponton, p. 80 , pl. 12, fig. 8 .

Bolivina plicatella Cushman var. mera Cushman and Ponton, p. 82 , pl. 12 , figs. 4 a, b.

Bolivina advena Cushman, p. 83, pl. 12, fig. 3 .

Bolivina robusta $\mathrm{H}$. B. Brady, p. 83 , pl. 12 , fig. 5 .

Uvigerina peregrina Cushman, p. 85.

Uvigerina parkeri Karrer, p. 86, pl. 12, figs. 12a, b.

Patellina corrugata Williamson, p. 87, pl. 13, figs. 1a, b.

Discorbis candeiana (D'Orbigny) var. bullata Cushman and

Ponton, p. 89, pl. 13, figs. 5a-c.

Lamarckina atlantica Cushman, p. 91, pl. 13, figs. 7a-c. Eponides repandus (Fichtel and Moll), p. 92, pl. 13, figs. 9a-c.

Eponides antillarum (D'Orbigny), p. 93, pl. 14, figs. 1a-c. Siphonina jacksonensis Cushman and Applin var. limbosa

Cushman, p. 94, pl. 14, figs. 2a-c.

Asterigerina carinata D'Orbigny, p. 94.
Asterigerina miocenica Cushman and Ponton, p. 95, pl. 14, figs. $4 a-c$.

Amphistegina floridana Cushman and Ponton, p. 96, pl. 14, figs. 6,7 .

Amphistegina chipolensis Cushman and Ponton, p. 96, pl. 15, figs. 1a-c.

Cassidulina chipolensis Cushman and Ponton, p. 98, pl. 15, figs. $2 \mathrm{a}-\mathrm{c}$.

Hastigerina pelagica (D'Orbigny), p. 99.

Orbulina universa D'Orbigny, p. 99.

Cycloloculina miocenica Cushman and Ponton, p. 99, pl. 15, figs. $3,4$.

Cibicides refulgens (Montfort), p. 101.

Cibicidella variabilis (D'Orbigny), p. 102, pl. 15, figs. 5-7. Annulocibicides projectus Cushman and Ponton, p. 103, pl. 16, figs. 1a, b.

Rectocibicides miocenicus Cushman and Ponton, p. 103, pl. 16, figs. $2-4$.

Acervulina chipolensis Cushman and Ponton, p. 104, pl. 16, figs. 7, 8.

Gypsina vesicularis (Parker and Jones), p. 105, pl. 16, figs. $9 \mathrm{a}, \mathrm{b}$.

The Miocene Foraminifera of this region are very definitely related to the present-day fauna off these same shores. Some of the localities have species which are characteristic of warm-water localities in the present West Indian and Florida regions and undoubtedly represent deposits in warmer waters. Many of these species are not known from the Northern States. On the other hand, many of the species of the Calvert formation of Maryland, for instance, do not extend southward to Florida and undoubtedly represent deposits in colder waters.

There are numerous species that differ specifically from the living allied species now found off these same coasts. Other species are of especial interest, as they represent Miocene American forms closely related to Miocene species known hitherto only from central Europe. Examples of this are seen in the genus Pseudarcella and in some of the species of Virgulina.

Owing to the newer methods of flotation in carbon tetrachloride, even sands that are relatively poor in Foraminifera have yielded a very fair fauna, and a great deal of time has been saved in the handling of this material. By this method it is possible to determine also the relative abundance of many of the species, a feature not previously determinable.

The accompanying table shows the distribution by stations grouped according to States and formations. The United States Geological Survey station numbers are used so far as available; for material that came from other sources, the locality itself is given in abbreviated form. A reference to the list of stations will give the full data for all these localities.

Our thanks are due to numerous persons for supplying materials used in the present studies. These have been obtained chiefly by Dr. W. C. Mansfield, of the United States Geological Survey, and Dr. R. S. Bassler, of the United States National Museum. Thanks are also due to Mr. Herman Gunter, State 
geologist of Florida, for his cooperation in allowing the use of many of the original drawings prepared for Florida Geological Survey Bulletin 4. Credit should be given to Miss Margaret S. Moore, for her careful drawing of the specimens illustrating this report, both those of the earlier Florida report and the additional ones here included, and to Miss Alice E. Cushman and Miss Elizabeth C. Knott for their work in preparing the manuscript and tables. Miss Frances L. Parker also rendered valuable aid in picking out and mounting the material from the Chesapeake Beach section.

The holotypes and figured specimens are to be deposited in the collections of the United States National Museum, and paratypes of the new species and duplicates of the others so far as these are available are in the collections of the Cushman Laboratory at Sharon, Mass.

\section{LOCALITIES OF FORAMINIFERAL MATERIAL}

The numbers given are those of the United States Geological Survey catalogue of Tertiary localities, the fraction signifying numbers above 10000 - for example, $1 / 953$ means 10953 . This system is not now being followed, but localities originally so numbered are still listed in this fashion.

\section{CHOCTAWHATCHEE FORMATION OF FLORIDA}

BAY COUNTY

1/953. R. L. Gainer farm, on Econfina River, about 1 mile below Econfina Bridge, sec. 4, T. 1 S., R. 13 W., Bay County, Fla. W. C. Mansfield, collector, Oct. 30, 1925.

1/682. Bryant Scott's farm, a quarter of a mile above mouth of branch entering Econfina Creek near bridge at Econfina, Bay County, Fla. Julia A. Gardner, collector, Nov. 14, 1923.

\section{CALHOUN COUNTY}

1/954. Fourmile Creek, half a mile northwest of Clarksville, Calhoun County, Fla.; lowest bed exposed in the creek. W. C. Mansfield, collector, Nov. 2, 1925.

1/960. Darlings Slide, about $2 \frac{1}{2}$ miles (air line) southeast of Clarksville, Calhoun County, Fla. W. C. Mansfield, collector, Nov. 2, 1925.

\section{LEON COUNTY}

1/946. SW. $1 / 4$ sec. 9, T. 1 S., R. 3 W., on Harveys Creek about $1 \frac{1}{2}$ miles southeast of road from Tallahassee to Bloxham, Leon County, Fla. W. C. Mansfield, collector, Nov. 14, 1925.

1/964. Sec. 8 , T. 1 S., R. 3 W., small stream entering Harveys Creek at an abandoned mill, Leon County, Fla.; highest bed exposed. W. C. Mansfield, collector, Nov. 16, 1925.

1/965. Sec. 8 , T. 1 S., R. 3 W., Harveys Creek at abandoned mill about half a mile above road leading to Bloxham, Leon County, Fla.; lower bed of the Choctawhatehee, here exposed and resting upon Alum Bluff group. W. C. Mansfield, collector, Oct. 17 and Nov. 15, 1925.

1/966. Double Branch, about 6 miles east of Jackson Bridge, sec. 8 , T. 1 S., R. 3 W., just above the bridge on road to Jackson Bridge, Leon County, Fla. W. C. Mansfield, collector, Oct. $17,1925$.

1/967. Lower upper Miocene bed at Jackson Bluff, left bank of Ochlockonee River, just above the bridge, Leon County, Fla. W. C. Mansfield, collector, Oct. 16, 1925.
LIBERTY COUNTY

1/670. Upper fossiliferous bed at Alum Bluff, Apalachicola River, Liberty County, Fla. Julia A. Gardner, collector, Dec. 23, 1923.

1/956. Upper fossiliferous bed at Alum Bluff, Apalachicola River, Liberty County, Fla. W. C. Mansfield and E. C. Bracewell, collectors, Nov. 5, 1925.

1/958. Old Coe's Mill, about $1 \frac{11}{2}$ miles northwest of Hosford, Liberty County, Fla. W. C. Mansfield and E. C. Bracewell, collectors, Nov. 6, 1925.

1/961. On S. D. Johnson's place near Woods, sec. 26, T. 1 S., R. 8 W., Liberty County, Fla. W. C. Mansfield and E. C. Bracewell, collectors, Nov. 7, 1925.

1/962. Cut in road leading to Watson's Landing, about 2 miles north of Alum Bluff, Liberty County, Fla. Choctawhatchee formation. W. C. Mansfield and E. C. Bracewell, collectors, Nov. 10, 1925.

\section{WALTON COUNTY}

1/671. Red Bay, Jim Kennedy Branch, Walton County, Fla. Julia A. Gardner, collector, Oct. 26, 1923.

1/673. E. Gomillion's place, Red Bay, Walton County, Fla. Julia A. Gardner, collector, Oct. 26, 1923.

1/947. Jim Kennedy Branch, about 1 mile east of Red Bay, Walton County, Fla.; lowest fossiliferous bed. W. C. Mansfield, collector, Oct. 24, 1925.

1/948. John Anderson farm, three-fourths of a mile east of Red Bay, Walton County, Fla. W. C. Mansfield, collector, Oct. 20, 1925 .

1/950. E. Gomillion's place, about half a mile east of Red Bay and about one-fifth of a mile from the Gomillion residence, Walton County, Fla. W. C. Mansfield, collector, Oct. 20, 1925.

\section{WASHINGTON COUNTY}

1/422. Hamlin Pond, near range line between T. 1 N., R. 13 W., and T. 1 N., R. 14 W., about 10 miles south of Wausau, Washington County, Fla. C. W. Cooke and Julia A. Gardner, collectors, June 25, 1921.

1/706. Gully Sink, probably in sec. 14, T. 1 N., R. 14 W., about 10 miles south of Wausau, Washington County, Fla. C. W. Cooke and Julia A. Gardner, collectors, June 25, 1921.

1/955. Gully Sink, T. 2 N., R. 14 (?) W., Washington County, Fla. W. C. Mansfield, collector, Oct. 29, 1925.

Old Frazier farm, NW. 1/4 SE. $1 / 4$ sec. 18, T. 2 N., R. 19 W., Baker County, Fla.

\section{DUPLIN MARL, SOUTH CAROLINA}

Muldrows Mills, S. C.

Mayesville, S. C.

Beech Bank, Edisto River, S. C.

\section{DUPLIN MARL, NORTH CAROLINA}

6316. Wilmington, N. C.

11820. Marl pit on A. R. Chesnut's farm, 3 miles southwest of Kenansville, Duplin County, N. C. W. C. Mansfield, collector, June 14, 1928.

11824. Road cut about 4 miles southeast of Lumberton, near hill at first crossing of Lumber River on road to Wilmington, Robeson County, N. C. W. C. Mansfield, collector, May 29, 1928.

11831. On John Miller's place, three-quarters of a mile south of Poplar Grove and about 5 miles west of Faison, Sampson County, N. C. W. C. Mansfield, collector, June 25, 1928.

\section{YORKTOWN FORMATION, NORTH CAROLINA}

1/222. Right bank of Meherrin River at Murfreesboro, Hertford County, N. C., about one-eighth of a mile above highway 
bridge; lowest bed at water level and to 3 or 4 feet above. W. C. Mansfield, collector, June 10, 1922.

11835. Right bank of Tar River at Boyd Bridge, about 1 mile north of Grimesland, Pitt County, N. C.; exposed up to about 8 feet above the water level. W. C. Mansfield, collector, June $19,1928$.

11836. Marl pit on W. G. Peacock's place, about $1 \frac{1 / 4}{4}$ miles east of Fremont, Wayne County, N. C. W. C. Mansfield, collector, June 27, 1928.

11837. Marl pile about 5 miles slightly southwest of Washington and about 1 mile north of main road between Greenville and Washington, Beaufort County, N. C. W. C. Mansfield, collector, June 19, 1928.

\section{YORKTOWN FORMATION, VIRGINIA}

1/188. Lowest portion of the Turritella bed of Harris, right bank of York River 2 miles below Yorktown, Va., about oneeighth mile below United States fuel station. W. C. Mansfield, collector, May 19, 1922.

1/193. About $1 \frac{1}{4}$ miles below Yorktown, half a mile below prominent projecting point, York River, York County, Va.; lower bed of fragmental series. W. C. Mansfield, collector, May 19, 1922.

1/201. Bank of Nansemond River, rising from tidal flats at Suffolk, Nansemond County, Va.; exposure well shown here, the bank having been cut by oil company in placing of storage tanks; Mulinia congesta very abundant. W. C. Mansfield, collector, May 24, 1922.

$1 / 205$. Bed 3 , or the comminuted bed, in section along Tormentor Creek, Isle of Wight County, Va. W. C. Mansfield, collector, May 25, 1922.

1/216. Left bank of Nottoway River at bend at Sycamore, Southampton County, Va. W. C. Mansfield, collector, June 2, 1922; supplementary collection by W. C. Mansfield and W. P. Popenoe, June 25, 1927.

1/234. Lower bed exposed from water level to $4 \frac{1}{2}$ feet above, on right bank of James River just below Fergusons Wharf (=Rushmere), Isle of Wight County, Va. W. C. Mansfield, collector, June 16, 1922.

1/251. About half a mile above Baylor Lane, western branch of Lieutenant Run, western section of Petersburg, Dinwiddie County, Va.; upper bed. W. C. Mansfield, collector, June 24, 1922; supplementary collection by W. C. Mansfield and W. P. Popenoe, June, 1927.

1/470a. Just below Old Grove Wharf, left bank of James River, about 2 miles below Camp Wallace, James City County, Va.; lowest bed exposed in section. W. C. Mansfield, collector, June 22, 1923.

\section{ST. MARYS FORMATION, VIRGINIA}

1/241. Just below College Run on Cobham Bay, rightbank of James River, Surry County, Va.; bed outcropping at water level. W. C. Mansfield and J. Green, collectors, June 17, 1922. 1/543. Half a mile to 1 mile below Sunken Marsh Creek, James River, Surry County, Va.; lowest bed, basal bed along river. W. C. Mansfield, collector, Oct. 16, 1923.

\section{CALVERT FORMATION, MARYLAND}

Chesapeake Beach, Md.

Plum Point, Md.

Near Centerville, Md.

\section{CHOPTANK FORMATION, MARYLAND}

1/750. Point of Rocks, about $1 \frac{1}{2}$ miles below Flag Pond, Chesapeake Bay, Calvert County, Md.; bed directly beneath the first indurated layer above the beach; top of bed is about 20 feet above the beach; zone 19 of Maryland report. W. C. Mansfield and W. P. Popenoe, collectors, Nov. 15, 1924.

1/752. About $2 \frac{1}{2}$ miles below Governor Run, Chesapeake Bay, Calvert County, Md.; the most fossiliferous bed, which crops out 3 to 4 feet above the beach up to about 18 feet; zone 17 of the Maryland Geological Survey. W. C. Mansfield and W. P. Popenoe, collectors, Nov. 16, 1924.

1/753. One mile above Governor Run, Chesapeake Bay, Calvert County, Md.; lower fossiliferous bed of the Choptank formation, or zone 17 of the Maryland Geological Survey; the base of this bed is about 28 to 30 feet above the beach. W. C. Mansfield and W. P. Popenoe, collectors, Nov. 14, 1924.

1/754. Half a mile above Governor Run, Chesapeake Bay, Calvert County, Md.; highest fossiliferous zone, or zone 19 of the Maryland Geological Survey; the base of this bed is about 55 feet above the beach. W. C. Mansfield and W. P. Popenoe, collectors, Nov. 14, 1924.

\section{ST. MARYS FORMATION, MARYLAND}

1/66. Just south of Chancellor Point, St. Marys County, Md. W. C. Mansfield, collector, June 14, 1920.

1/748. Little Cove Point and a little below, Chesapeake Bay, Calvert County, Md.; second bed, the base of which is about 20 feet above the beach. W. C. Mansfield and W. P. Popenoe, collectors, Nov. 17, 1924.

1/749. Same as $1 / 748$; a general collection taken from all the beds. W. C. Mansfield and W. P. Popenoe, collectors, Nov. 17, 1924.

1/903. About 1 mile above site of Langley house, Langleys Bluff, Chesapeake Bay, St. Marys County, Md.; just below contact with Pleistocene. L. W. Stephenson, W. C. Mansfield, and W. P. Popenoe, collectors, June 27, 1925.

\section{SECTION OF CALVERT FORMATION AT CHESAPEAKE BEACH, MD.}

The cliffs at Chesapeake Beach have long been known as a classic locality for Miocene fossils of various groups. A considerable number of Foraminifera have been previously recorded from this locality. On a visit to this locality with Dr. R. S. Bassler, of the United States National Museum, it occurred to the senior author that it might be interesting to see what a close study of the Foraminifera of the different beds might show in the way of selective distribution. As a result Doctor Bassler later collected a series of eight samples from the Chesapeake Beach section which were studied in detail. The position of these samples is indicated by Doctor Bassler in the accompanying section of the beds at Chesapeake Beach. ${ }^{3}$ His numbers are given in parentheses at the left.

\section{Chesapeake Beach section}

Feet

Yellow sandy clay (zone 15)

9

Yellow sandy clay (zone 14) ..................

(8) Blue sandy clay changing to yellowish-brown sandy clay in the upper 12 feet, fossiliferous throughout upper portion (zone 13) .......................

Greenish-brown sandy clay bearing fossil casts (zone 12) _.

Greenish-brown sandy clay (zone 11) 32

3 Shattuck, G. B., Maryland Geol. Survey, Miocene, p. lxxxvii, 1904. 
(7) Grayish-green sand containing some clay carrying ( Turritella indentata, Phacoides anodonta, Crassatel-

6) Pecten madisonius, Macrocallista marylandica, Atrina harrisii, Arca subrostrata, Glycimeris parilis, etc. (zone 10)

(5) Greenish sandy clay carrying scattered layers of Corbula elevata (zone 9) .......................

(4) Greenish sandy clay apparently devoid of fossils

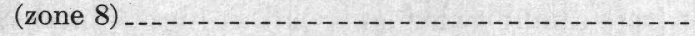

Greenish sandy clay carrying scattered layers of Corbula elevata (zone 7) _...........................

(3) Greenish sandy clay carrying large numbers of Corbula elevata (zone 6) ...........

(2) Greenish sandy clay carrying Thracia conradi (zone

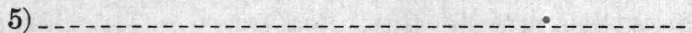

(1) Greenish sandy clay carrying Ostrea percrassa (zone 4) _..............

Bluish-green sandy clay revealed in well boring (zones 3, 2, and 1)

Glauconitic sandy clay (Eocene).

The subjoined table shows the relative abundance of the more common species of Foraminifera in this section. Lot 8 yielded no Foraminifera and is not shown. It will be seen that such a striking species as Spiroplectammina gracilis is common in beds 1 and 2 but is not found above, while Rotalia bassleri is common in all beds above No. 1. Pseudopolymorphina striata, one of the largest and most easily identified species, is common only in the upper three beds and is almost wanting below. Thus in a well bored in the Calvert formation we would expect to be able to distinguish definite zones, even though the larger Mollusca might have been destroyed in drilling.

Distribution and relative abundance of Foraminifera in section at Chesapeake Beach, $M d$.

[ve, Very common; c, common; f, fairly common; $r$, rare]

\begin{tabular}{|c|c|c|c|c|c|c|c|}
\hline & 1 & 2 & 3 & 4 & 5 & 6 & \\
\hline racilis_. & c & c & & - & - - & $r$ & \\
\hline $\begin{array}{l}\text { Textularia agglutinans } \\
\text { articulata }\end{array}$ & f & -- & c & - & $r$ & $\mathrm{r}$ & \\
\hline Lagena perlucida & - & - & $f$ & -- & - & $\mathrm{f}$ & \\
\hline clavata & $\mathrm{f}$ & $\mathbf{r}$ & $\mathrm{c}$ & $\mathrm{r}$ & $\mathrm{c}$ & c & \\
\hline sub & - & - & $\mathrm{r}$ & - & $\mathrm{c}$ & c & \\
\hline aphora_.- & - & $\mathbf{r}$ & -- & -- & $r$ & -- & \\
\hline orbign & & & & & -- & & \\
\hline cf. L. $\mathrm{n}$ & -- & -- & - & - & - & $\mathbf{r}$ & \\
\hline Pyrulina alba & & & & & & & \\
\hline Globuli & & & & - & & & \\
\hline hina dumblei & $\mathrm{r}$ & -- & - - & - - & & & \\
\hline 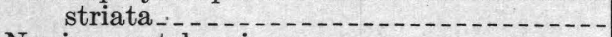 & $r$ & $\cdots$ & -- & - & c & ve & \\
\hline$i_{1}$ & -- & -- & $\mathbf{r}$ & $\ldots$ & -- & -- & \\
\hline - - - - - - - - - - - & $\mathrm{c}$ & c & c & c & ve & c & \\
\hline 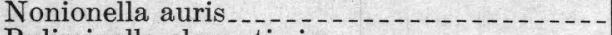 & c & -- & c & c & c & c & \\
\hline legantissima_............. & $\mathrm{c}$ & c & c & -- & c & f & \\
\hline - & c & c & c & c & c & c & \\
\hline$-1-2-1-1--1$ & c & -- & c & $\mathrm{r}$ & f & c & \\
\hline inata var. multicostata... & $r$ & $f$ & $f$ & - & - & f & \\
\hline & $f$ & $f$ & f & -- & -- & $\mathbf{r}$ & \\
\hline paula & $f$ & f & $f$ & c & $\mathrm{c}$ & c & \\
\hline $\begin{array}{l}\text { Loxostomum gunteri } \\
\text { Uvigerina ef. U. pigmea }\end{array}$ & $f$ & f & $f$ & -- & r & r & \\
\hline , & & & & & 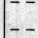 & f & \\
\hline ngulogerina occidentalis & $r$ & & & & & - - & \\
\hline llipsolagena bidens & & & & & & & \\
\hline
\end{tabular}

Distribution and relative abundance of Foraminifera in section at Chesapeake Beach, Md.-Continued

[vc, Very common; c, common; f, fairly common; r, rare]

\begin{tabular}{|c|c|c|c|c|c|c|c|}
\hline & 1 & 2 & 3 & 4 & 5 & 6 & 7 \\
\hline Discorbis rosacea_ & f & -- & $\mathrm{f}$ & -- & -- & $\mathrm{f}$ & f \\
\hline orbicularis & -- & -- & $\mathrm{r}$ & -- & -- & -- & \\
\hline consobrina_. & $\mathrm{f}$ & -- & -- & -- & -- & $\mathrm{r}$ & \\
\hline valvulata & - & $\mathrm{f}$ & $\mathrm{r}$ & $\mathrm{f}$ & $\mathbf{r}$ & -- & - \\
\hline Valvulineria floridana & $\mathrm{c}$ & $\mathrm{f}$ & $\mathrm{c}$ & f & $\mathrm{c}$ & c & c \\
\hline Rotalia bassleri & - & c & c & $\mathrm{f}$ & c & c & \\
\hline Cancris sagra & - & -- & -- & -- & -- & $\mathrm{r}$ & \\
\hline Cassidulina crassa & - & - & -- & $r$ & - & -- & \\
\hline Cibicides concentricus & - & - & - & -- & - & $\mathrm{f}$ & $\mathrm{f}$ \\
\hline lobatulus var. ornatus & c & c & c & c & c & c & $\mathrm{c}$ \\
\hline
\end{tabular}

DESCRIPTIONS OF SPECIES

Family SACCAMMINIDAE

Subfamily PSAMMOSPHAERINAE

Genus PSAMMOSPhaERA F. E. Schultze, 1875

Psammosphaera fusca F. E. Schultze(?)

Plate 1, Figures 1a, b

A single specimen here figured from the Choptank formation of Maryland apparently belongs to this species. The wall is compressed, of coarse sand grains, and there is no definite aperture.

Recent discoveries of well-preserved primitive arenaceous species of Foraminifera in the early Paleozoic make it possible that these very primitive forms may have a much larger range in the geologic series than the later developed higher calcareous forms.

\section{Subfamily SACCAMMININAE}

Genus PROTEONINA Williamson, 1858

Proteonina difflugiformis (H. B. Brady) (?)

Plate 1, Figures 2a, b

Test free, consisting of a single elongate oval or pyriform chamber with a more or less distinct tubular neck, usually tapering gradually from the body of the chamber, which is undivided; wall fairly thick, of sand grains of variable size, firmly cemented or in small specimens with an excess of cement and fairly smooth; aperture circular, simple, terminal. Length $0.25 \mathrm{~mm}$; breadth $0.18 \mathrm{~mm}$; thickness $0.10 \mathrm{~mm}$.

This species, which is extremely rare in the Choctawhatchee formation of Florida, occurs in somewhat greater numbers in the Duplin marl of North Carolina.

\section{Genus MILLETTELLA Rhumbler, 1903 \\ Millettella spinata Cushman and Cahill, n. sp.}

Plate 1, Figures 3a-c

Test very much compressed, the aperture at one side of the test, base with numerous spinose projections; wall arenaceous with much chitin, smoothly finished except for the base; aperture in a large depression extending from the middle of the test to the apex, and 
rounded. Length $0.16 \mathrm{~mm}$; breadth $0.14 \mathrm{~mm}$; thickness $0.075 \mathrm{~mm}$.

Holotype (No. 371737, U.S.N.M.) from U. S. Geological Survey station 11831, Duplin marl, on John Miller's place, three-fourths of a mile south of Poplar Grove and about 5 miles west of Faison, Sampson County, N. C.

This is a very distinctive species, although small, and is very constant in its characters so far as the specimens show. With its compressed form and peculiar aperture this belongs in the genus Millettella.

\section{Genus URNULINA Gruber, 1884}

\section{Urnulina compressa Cushman}

Urnulina compressa Cushman, Florida Geol. Survey Bull. 4, p. 15 , pl. 1, figs. 2a, b, 1930 .

Cushman and Ponton, Florida Geol. Survey Bull. 9, p. 39, 1932.

Test free, small, compressed, slightly longer than broad, greatest width at about the middle, basal end somewhat angular, apertural end broadly rounded; wall of a single layer of sand grains firmly cemented; aperture large, rounded, slightly at one side of the axis of the test. Length $0.25 \mathrm{~mm}$; breadth $0.20 \mathrm{~mm}$; thickness $0.12 \mathrm{~mm}$.

The only records for this species are those from the Choctawhatchee formation at Harveys Creek about $1 \frac{1}{2}$ miles southeast of road from Tallahassee to Bloxham, Leon County, Fla., collected by W. C. Mansfield, and one from the Oak Grove sand. This and the following species represent the only two records for this genus as a fossil. Both the species are small and might easily be overlooked on this account, as well as the fact that their color is similar to that of the grains of the material in which they are found.

Urnulina rotundata Cushman and Cahill, n. sp.

Plate 1, Figures $4 \mathrm{a}, \mathrm{b}$

Test globular, nearly spherical, except the apertural end, which is truncate, not compressed; wall composed of a single layer of sand grains, firmly cemented, somewhat roughened; aperture very large, circular. Length $0.30 \mathrm{~mm}$; breadth $0.25 \mathrm{~mm}$; thickness $0.25 \mathrm{~mm}$.

Holotype (No. 371738 , U.S.N.M.) from U. S. Geological Survey station 11831, Duplin marl, on John Miller's place, three-fourths of a mile south of Poplar Grove and about 5 miles west of Faison, Sampson County, N. C.

This species is quite distinct from Urnulina compressa Cushman, described from the Choctawhatchee formation of Florida. The species is globular, not compressed, but has the very large aperture characteristic of the genus. Several specimens from the typo locality show that the characters are constant.

\section{Genus PSEUDARCELLA Spandel, 1909}

Pseudarcella arenata Cushman

Plate 1, Figures 5a, b

Pseudarcella arenata Cushman, Florida Geol. Survey Bull. 4, p. 15, pl. 1, figs. 3a, b, 1930.

Cushman and Ponton, Florida Geol. Survey Bull. 9, p. 39, 1932.

Test free, about twice as broad as high, planoconvex in side view, dorsal side strongly convex, ventral side flattened and slightly concave in the middle, circular in outline; wall very thin, composed of distinct sand grains firmly cemented, somewhat chitinous; aperture circular with a simple, flattened tooth. Diameter 0.28 $\mathrm{mm}$; height $0.20-0.23 \mathrm{~mm}$.

This is a very small but distinct species which was described from the Choctawhatchee formation of Florida and occurs also in the Duplin marl of North Carolina.

The species is constant in its characters, although small. It probably has a somewhat wide range in the Miocene of the Atlantic Coastal Plain, but owing to its fragile test and small size, it may be easily overlooked or broken in the preparation of material. The genus is known from the upper Oligocene of Germany, France, and northern Italy, and the records from Florida and North Carolina indicate that its distribution will be found to be probably much greater than these present records show.

\section{Family TEXTULARIIDAE \\ Subfamily SPIROPLECTAMMININAE \\ Genus SPIROPLECTAMMINA Cushman, 1927}

Spiroplectammina gracilis (Von Muenster)

Plate 1, Figures 6, 7

Textularia gracilis Von Muenster, in Roemer, Neues Jahrb., 1838, p. 384, pl. 3, fig. 14.

Test elongate, tapering, the earliest chambers planispiral, later ones biserial, greatest breadth at the apertural end, periphery subacute; chambers distinct, increasing gradually in size as added, slightly inflated; sutures distinct, very slightly depressed, very slightly curved obliquely downward toward the periphery, slightly limbate; wall finely arenaceous but with much cement and very smoothly finished; aperture a low slit at the base of the inner margin of the last-formed chamber. Length $0.80-1.00 \mathrm{~mm}$; breadth $0.38-0.42$ $\mathrm{mm}$; thickness $0.18-0.20 \mathrm{~mm}$.

This species described by Von Muenster from the upper Oligocene of Germany occurs in considerable numbers in the Choptank and Calvert formations of Maryland. These specimens were compared with a series of specimens from the type locality from which Von Muenster's specimens came and seem to fit very 
closely with the characters of his species. His figure is very small, but with the description the characters can be rather definitely made out. The early chambers are distinctly spiral, placing this species in the genus Spiroplectammina. It occurs also in the Yorktown formation of North Carolina and Virginia.

\section{Subfamily TEXTULARIINAE}

Genus TEXTULARIA Defrance, 1824

Textularia agglutinans D'Orbigny

Plate 1, Figures 8a, b

Textularia agglutinans D'Orbigny, in De la Sagra, Histoire physique, politique et naturelle de l'île de Cuba, Foraminifères, p. 136, pl. 1, figs. $17,18,32,34,1839$.

Cushman, U. S. Geol. Survey Bull. 676, p. 46, pl. 9, fig. 6, 1918; U. S. Nat. Mus. Bull. 103, p. 52, pl. 19, fig. 3, 1918; U. S. Nat. Mus. Bull. 104, pt. 3, p. 7, pl. 1, figs. 4, 5, 1922; Florida Geol. Survey Bull. 4, p. 16, pl. 1, figs. 4a, b, 1930.

Cushman and Ponton, Florida Geol. Survey Bull. 9, p. 39, 1932.

Test elongate, tapering, somewhat compressed, the periphery rounded; chambers inflated, increasing in height toward the apertural end; sutures distinct, depressed; wall rather coarsely arenaceous but smoothly finished on the exterior; aperture an elongate slit in a well-marked depression of the inner border of the chamber. Length $0.85-1.10 \mathrm{~mm}$; breadth $0.55-0.65$ $\mathrm{mm}$; thickness $0.40-0.45 \mathrm{~mm}$.

This species, which was described by D'Orbigny from the West Indies, has a fairly wide distribution in the West Indian region and in the Pacific. As a fossil, however, it does not have the wide range that has been assigned to it by various authors, as a comparison of their figures with typical material shows. It is fairly common in typical form in the Miocene of Florida, North Carolina, Virginia, and Maryland.

Although $T$. agglutinans is recorded from beds as old as the Jurassic, it is very questionable whether the records earlier than the Tertiary really are identical with D'Orbigny's species.

\section{Textularia gramen D'Orbigny}

Plate 1, Figures 9a, b

Textularia gramen D'Orbigny, Foraminifères fossiles du bassin tertiaire de Vienne, p. 248, pl. 15, figs. 4, 6, 1846.

Cushman, U. S. Geol. Survey Bull. 676, pp. 8, 4.5, pl. 9, fig. 5 (not figs. 2, $3=T$. mayori), 1918; Florida Geol. Survey Bull. 4, p. 17, pl. 1, figs. 5a, b, 1930 .

Cushman and Ponton, Florida Geol. Survey Bull. 9, p. 39, 1932.

Test slightly longer than broad, compressed, periphery subacute, sides strongly divergent; chambers distinct, comparatively few, fairly high, the earlier ones strongly overlapping; sutures distinct, slightly depressed; wall finely arenaceous, smoothly finished; aperture elongate, in a definite groove at the base of the inner margin of the last-formed chamber. Length
0.60-0.75 $\mathrm{mm}$; breadth $0.35-0.45 \mathrm{~mm}$; thickness $0.22-0.25 \mathrm{~mm}$.

This species as it occurs in the Miocene of Florida and the area northward is very close to that described by D'Orbigny from the Miocene of the Vienna Basin. Under this name many things have been recorded, but the species as it occurs in the Vienna Basin is a very definite one. Besides occurring in the Miocene of Florida, there are specimens in the present collection from North Carolina, Virginia, and Maryland.

This is one of the species that has been recorded back to the Jurassic. A study of the earlier figures will show that the earlier records are subject to revision when a strict limit is placed on the specific characters. The typical form as developed in the Vienna Basin Miocene probably does not have a wider range than Oligocene to Recent.

\section{Textularia mayori Cushman \\ Plate 1, Figures 10a, b}

Textularia mayori Cushman, Carnegie Inst. Washington Pub. 311 , p. 23, pl. 2, fig. 3, 1922; U. S. Nat. Mus. Bull. 104, pt. 3, p. 7, 1922; Florida Geol. Survey Bull. 4, p. 17, pl. 1, figs. $6-8,1930$.

Cushman and Ponton, Florida Geol. Survey Bull. 9, p. 40, pl. 1, figs. 2, 3, 1932 .

Textularia gramen (in part) Cushman (not D'Orbigny), U. S. Geol. Survey Bull. 676, p. 45, pl. 9, figs. 2, 3 (not fig. 5), 1918.

Test compressed, increasing rapidly in breadth, especially in the microspheric form, initial end rounded, apertural end obliquely truncate; chambers often indistinct, periphery of the later chambers each with an elongate, conical, hollow, spinose projection, often broken at the tip, those of the early portion directed backward, the later ones extending outward; sutures only slightly depressed, curved; wall arenaceous, of angular sand grains with much fine cement, surface smoothly finished; aperture low, elongate, at the inner border of the last-formed chamber, in a reentrant of the border, with a thin lip above. Length $0.85-1.00$ $\mathrm{mm}$; breadth $0.60-0.70 \mathrm{~mm}$; thickness $0.30-0.35 \mathrm{~mm}$.

This species, which was found to be common in the Choctawhatchee formation of Florida, occurs also in the Miocene formations northward to Virginia but does not seem to occur in the Maryland material. In the present waters of this region the species does not seem to occur north of Cape Hatteras.

Although in its typical form this species develops prominent spinose projections from the base of the chambers at the periphery, these are not invariably developed, but the general characters of shape, compression, and characters of the wall will easily distinguish the species. A certain number of specimens in the collections show that the typical spinose forms are usually present with the others. Often the spinose projections are not developed until the last adult chambers, many of the young specimens being without them. 


\section{Textularia conica D'Orbigny}

Plate 1, Figures 11a, b

Textularia conica D'Orbigny, in De la Sagra, Histoire physique, politique et naturelle de l'île de Cuba, Foraminifères, p. 143, pl. 1, figs. 19, 20, 1839 .

H. B. Brady, Challenger Rept., Zoology, vol. 9, p. 365, pl. 43, figs. 13, 14; pl. 113, fig. 1, 1884 .

Goës, Harvard Coll. Mus. Comp. Zoology Bull., vol. 29, p. $43,1896$.

Cushman, U. S. Nat. Mus. Proc., vol. 59, p. 50, pl. 11, figs. 4-6, 1921; U. S. Nat. Mus. Bull. 100, vol. 4, p. 123, pl. 25, figs. 2a-c, 1921; Carnegie Inst. Washington Pub. 311, p. 24, pl. 2, fig. 4, 1922; U. S. Nat. Mus. Bull. 104, pt. 3, p. 22, pl. 5, figs. 5-7, 1922; Carnegie Inst. Washington Pub. 342, p. 15, pl. 1, fig. 6, 1924.

Test usually wider than high, triangular in front view, broadly oval in end view, slightly compressed, apex bluntly pointed; chambers comparatively few, distinct; sutures distinct, slightly depressed; wall arenaceous, smooth, or slightly roughened; aperture a narrow slit at the base of the inner margin of the last-formed chamber; color gray.

This species was described by D'Orbigny from the West Indian region and occurs commonly also in warm waters in the Indo-Pacific area. It was not noted in the Choctawhatchee formation of Florida, but there are typical specimens in the Duplin marl of North Carolina. It does not occur, however, in the Miocene material to the northward in Virginia and Maryland.

There are records for conical species from as far back as the Jurassic, but it is very doubtful if those preceding the Tertiary are really the same species, so far as study of Cretaceous material and the early figures seems to show.

\section{Textularia articulata D'Orbigny}

Plate 1, Figures 12a, b

Textularia articulata D'Orbigny, Foraminifères fossiles du bassin tertiaire de Vienne, p. 250, pl. 15, figs. 16-18, 1846.

Hosius, Naturhist. Ver. preuss. Rheinlande Verh., vol. 50, p. 109, 1893.

Bagg, Bull. Am. Paleontology, vol. 2, No. 10, p. 19, 1898; Maryland Geol. Survey, Miocene, p. 471, pl. 132, figs. $6,7,1904$.

Cushman, U. S. Geol. Survey Bull. 676, p. 46, 1918.

Cushman and Ponton, Florida Geol. Survey Bull. 9, p. 40, pl. 1, figs. 1a, b, 1932.

Test elongate, two or three times as long as broad, compressed, rather evenly tapering, with the greatest breadth toward the apertural end, periphery acute and slightly keeled; chambers distinct, ten or more pairs in the adult, high and increasing in height toward the apertural end; sutures distinct, somewhat curved, extending strongly backward; wall distinctly arenaceous, with much cement, smoothly finished; aperture fairly large, at the base of the inner margin of the chamber. Length $0.60-0.75 \mathrm{~mm}$; breadth $0.30-0.35 \mathrm{~mm}$; thickness $0.18-0.20 \mathrm{~mm}$.

This species was originally described by D'Orbigny from the Miocene of the Vienna Basin, where it is fairly common and of distinctive character. The Miocene material from Maryland is very typical. Bagg has already recorded it from the Calvert formation of Plum Point and Chesapeake Beach, Md. We have had very typical material from the latter station. It was also recorded by Bagg from the James River in Virginia and has recently been recorded from the Miocene of Florida (Choctawhatchee, Shoal River, and Oak Grove).

It may be noted that the "Textularia articulata Reuss" from the Cretaceous is a species of Spiroplectoides.

\section{Textularia floridana Cushman \\ Plate 1, Figures 13a, b}

Textularia transversaria Flint (not H. B. Brady), U. S. Nat. Mus. Rept. for 1897, p. 283, pl. 28, fig. 4, 1899.

Textularia floridana Cushman, Carnegie Inst. Washington Pub. 311, p. 24, pl. 1, fig. 7, 1922; U. S. Nat. Mus. Bull. 104 , pt. 3, p. 18, pl. 2, figs. 11, 12, 1922; Florida Geol. Survey Bull. 4, p. 18, pl. 1, figs. 9a, b, 1930.

Cushman and Ponton, Florida Geol. Survey Bull. 9, p. 41, 1932.

Test elongate, two or three times as long as wide, much compressed, periphery entire or broken, in the adult with the sides nearly parallel, initial end rather sharply pointed, apertural end broadly rounded or truncate; chambers numerous, thickest near the center, increasing somewhat in height toward the apertural end, the peripheral portions thin-walled and often broken away; sutures nearly at right angles to the periphery, slightly if at all depressed; wall finely arenaceous, smooth; aperture small, rounded, at the base of the inner margin of the last-formed chamber. Figured specimen, length $0.40 \mathrm{~mm}$ : breadth $0.20 \mathrm{~mm}$; thickness $0.10 \mathrm{~mm}$.

This species occurs in the Choctawhatchee formation of Florida, where it was represented by a single specimen from Gully Sink, Washington County, Fla. It has not occurred in the Miocene material in the. States to the north. As a Recent species it is confined to the West Indian region and the coast of Florida.

Genus BIGENERINA D'Orbigny, 1826

Bigenerina nodosaria D'Orbigny var. textularioidea (Goës)

\section{Plate 1, Figure 14}

Textularia sagittula Defrance forma bigenerina Goës, K. Svensk. Vet. Akad. Handl., vol. 19, pt. 4, p. 78, pl. 5, figs. 159, 160, 1882.

Clavulina textularioidea Goës, idem, vol. 25 , p. 42 , pl. 8, figs. 387-399, 1894; Harvard Coll. Mus. Comp. Zoology Bull., vol. 29, p. 37, pl. 4, figs. 26-38, 1896.

Bigenerina nodosaria Flint, U. S. Nat. Mus. Rept. for 1897 , p. 286, pl. 31, fig. 4, 1899.

Cushman, U. S. Nat. Mus. Proc., vol. 59, p. 51, 1921; Carnegie Inst. Washington Pub. 311, p. 25, pl. 2, figs. $5,6,1922$.

Bigenerina nodosaria D'Orbigny var. textularioidea Cushman, U.S. Nat. Mus. Bull. 103, pt. 3, p. 25, pl. 5, figs. 8, 9, 1922; Florida Geol. Survey Bull. 4, p. 18, pl. 1, fig. 10, 1930.

Cushman and Ponton, Florida Geol. Survey Bull. 9, p. 42, pl. 1, fig. 8, 1932 . 
Variety differing from the typical form in the larger size, much greater proportion of the uniserial stage, and reduction of the biserial portion as well as in the relation of the two, the last-formed chambers of the test often being greater in size than the entire biserial portion. Length of the fossil specimens slightly less than $1.00 \mathrm{~mm}$; diameter $0.20 \mathrm{~mm}$.

Specimens are rare in the Choctawhatchee formation, a few specimens being found on Harveys Creek about $1 \frac{1}{2}$ miles southeast of road from Tallahassee to Bloxham, Leon County, and a single specimen from Gully Sink, Washington County, Fla., all collected by W. C. Mansfield.

The few fossil specimens are not as well developed as the recent ones of the Florida coast and the West Indies, and apparently the greater development of this form in the West Indian region has taken place since the Miocene.

No specimens of this species have occurred in the collection studied from the States north of Florida. It is one of the characteristic West Indian species in warm shallow waters.

\section{Family MULIOLIDAE \\ Genus QUINQUELOCULINA D'Orbigny, 1826}

Quinqueloculina cf. Q. fusca H. B. Brady

Plate 2, Figures 1a-c

In the Florida collections specimens were referred to this species with some doubt. In the material to the north the same form has occurred, but only as a single specimen at one station in Maryland.

\section{Quinqueloculina seminula (Linné)}

Plate 2, Figures 2a-c

"Conchula minima arcte in se contorta, etc." Plancus, De conchis minus notis, p. 19, pl. 11, figs. 1A, B, C, 1739.

"Tubulus marinus irregulariter intortus vermicularis" Gualtieri, Index testarum conchyliorum, pl. 10, fig. S, 1742.

Serpula seminulum Linné, Systema naturae, 12th ed., p. 1264, 1767.

Quinqueloculina seminulum D'Orbigny, Annales sci. nat., vol. 7, p. 303, 1826.

Cushman, U. S. Nat. Mus. Bull. 103, p. 78, pl. 27, figs. 4a, b; pl. 28, figs. 1-3; pl. 29, figs. 1a-c, 1918; U. S. Geol. Survey Bull. 676 , pp. 22, 70, pl. 1, fig. 8; pl. 28, figs. 2, 4, 5; pl. 29, fig. 1, 1918; U. S. Nat. Mus. Bull. 104, p. 24, pl. 2, figs. 1, 2, 1929; Florida Geol. Survey Bull. 4, p. 19, pl. 2, figs. 1, 2, 1930.

Cushman and Ponton, Florida Geol. Survey Bull. 9, p. 43, 1932.

Miliolina seminulum Williamson, Recent Foraminifera of Great Britain, p. 85, pl. 7, figs. 183-185, 1858.

H. B. Brady, Challenger Rept., Zoology, vol. 9, p. 157, pl. 5, fig. 6, 1884.

Test longer than wide, greatest width near the middle; chambers distinct, of nearly uniform diameter, periphery rounded; sutures distinct, very slightly depressed; wall smooth, polished; aperture large, with a simple tooth. Length $1.00 \mathrm{~mm}$; breadth $0.50-0.55$ $\mathrm{mm}$; thickness $0.22-0.25 \mathrm{~mm}$.
This species, which was rare in the Choctawhatchee formation of Florida, occurs in much greater numbers in the Miocene material to the north, being especially abundant in material from Maryland and somewhat less so in that from Virginia.

\section{Quinqueloculina lamarckiana D'Orbigny}

Plate 2, Figures 4a-c

Quinqueloculina lamarckiana D'Orbigny, in De la Sagra, Histoire physique, politique et naturelle de l'île de Cuba, Foraminifères, p. 189, pl. 11, figs. 14, 15, 1839.

Cushman, U. S. Nat. Mus. Proc., vol. 59, p. 65 , pl. 15, figs. 13, 14, 1921; Carnegie Inst. Washington Pub. 311, p. 64 , 1922; Pub. 342 , p. 63 , 1924; Pub. 344, p. 81 , 1926; U. S. Nat. Mus. Bull. 104, pt. 6, p. 26, pl. 2, figs. 6a-c, 1929; Florida Geol. Survey Bull. 4, p. 20, pl. 2, figs. 3-5, 1930.

Cushman and Ponton, Florida Geol. Survey Bull. 9, p. 44, 1932.

Quinqueloculina auberiana D'Orbigny, in De la Sagra, op. cit., p. 193, pl. 12, figs. 1-3, 1839.

Cushman, U. S. Nat. Mus. Bull. 103, p. 79 , pl. 29, figs. 3a-c, 1918; U. S. Geol. Survey Bull. 676, pp. 23, 71, pl. 5, fig. 3; pl. 30, fig. 1, 1918.

Quinqueloculina cuvieriana H. B. Brady (not D'Orbigny), Challenger Rept., Zoology, vol. 9, p. 162, pl. 5, figs. $12 \mathrm{a}-\mathrm{c}, 1884$.

Test nearly as broad as long; chambers distinct, generally triangular in transverse section, the angles subacute but not carinate; sutures slightly depressed; wall smooth and polished; apertural end of chamber slightly extended, forming an elliptical neck without a definite lip, but with a narrow, elongate tooth. Fossil specimens, length $0.80 \mathrm{~mm}$; breadth $0.50 \mathrm{~mm}$; thickness $0.40 \mathrm{~mm}$.

This species was recorded as rare in the Choctawhatchee formation of Florida and is also rare in the material from the States to the north, occurring only in Virginia.

\section{Quinqueloculina contorta D'Orbigny}

Plate 2, Figures 3a-c

Quinqueloculina contorta D'Orbigny, Foraminifères fossiles du bassin tertiaire de Vienne, p. 298, pl. 20, figs. 4-6, 1846.

Cushman, U. S. Nat. Mus. Bull. 104, pt. 6, p. 29, pl. 3, figs. 6a-c, 1929; Florida Geol. Survey Bull. 4, p. 20, pl. 2, figs. 6a-c, 1930.

Cushman and Ponton, Florida Geol. Survey Bull. 9, p. 44, 1932.

Miliolina contorta H. B. Brady, Roy. Micr. Soc. Jour., p. 881, 1887.

Heron-Allen and Earland, Roy. Irish Acad. Proc., vol. 31, pt. 64, p. 30, 1913; Linnean Soc. London Trans., Zoology, vol. 11, p. 213, 1916.

Test somewhat longer than broad; chambers polygonal in transverse section, periphery and sides flattened or slightly concave, angles subacute; sutures distinct, slightly depressed; wall smooth; aperture rounded, slightly projecting, with a simple tooth. Length 0.75 $\mathrm{mm}$; breadth $0.45 \mathrm{~mm}$; thickness $0.18-0.20 \mathrm{~mm}$.

This species is rare in the Choctawhatchee formation and is very rare in the material to the north, 
occurring at a single station in the Choptank formation of Maryland.

\section{Quinqueloculina subpoeyana Cushman}

Plate 2, Figures 5a, b

Quinqueloculina subpoeyana Cushman, Carnegie Inst. Washington, Pub. 311, p. 66, 1922; U. S. Nat. Mus. Bull. 104, pt. 6 , p. 31, pl. 5, figs. 3a-c, 1929; Florida Geol. Survey Bull. 4, p. 21, pl. 2, figs. 7a, b, 1930.

Cushman and Ponton, Florida Geol. Survey Bull. 9, p. 44, pl. 2, figs. $4 \mathrm{a}-\mathrm{c}, 1932$.

Test elongate, about two and a half times as long as wide; chambers distinct, peripheral border rounded, apertural end projecting; sutures somewhat obscured; wall ornamented by numerous longitudinal costae which, instead of being uniform, are usually irregularly toothed throughout, giving a peculiar roughened appearance to the test; aperture with a thin lip and a single tooth. Length of figured specimen $0.35 \mathrm{~mm}$; breadth $0.18 \mathrm{~mm}$; thickness $0.12 \mathrm{~mm}$.

This species, which is common in a living state off the coast of Florida and in the general West Indian region, is very rare in the Miocene Choctawhatchee formation, and was not found in any of the material examined from the States to the north. This is not surprising, as it is a typically warm-water species.

Genus SPIROLOCULINA D'Orbigny, 1826

Spiroloculina planulata (Lamarck)

Plate 2, Figures $6 a$, b

Spiroloculina planulata (Lamarck) Cushman, Florida Geol. Survey Bull. 4, p. 21, pl. 3, figs. 1a, b, 1930.

Cushman and Ponton, Florida Geol. Survey Bull. 9, p.49, 1932.

Test irregularly elliptical, periphery in the young convex, in the adult becoming flattened or concave; chambers distinct, the initial end projecting considerably beyond the aperture of the previously formed one, the apertural end very slightly, if at all, projecting, side view concave; sutures distinct; surface matte; aperture with a slight lip and an elongate tooth, often slightly bifid at the tip. Length of figured specimen $0.43 \mathrm{~mm}$; breadth $0.30 \mathrm{~mm}$; thickness $0.10 \mathrm{~mm}$.

The only occurrence in the Miocene material is that from the Choctawhatchee formation of Florida, a figure of which is copied here.

\section{Spiroloculina depressa D'Orbigny}

Plate 2, Figures 7a, b

Spiroloculina limbata Cushman, (not D'Orbigny), U. S. Geol. Survey Bull. 676, p. 72, pl. 31, figs. 2a, b, 1918.

Cushman and Ponton, Florida Geol. Survey Bull. 9, p. 49, 1932.

This species was previously recorded from the Choctawhatchee formation at Jackson Bluff as Spiroloculina limbata D'Orbigny. The figure is copied here for reference, but no further specimens have been found.

\section{Spiroloculina sp.?}

Plate 2, Figure 8

Spiroloculina sp.? Cushman, Florida Geol. Survey Bull. 4, p. 22, pl. 3, fig. 3, 1930.

A copy of the figure of the single specimen from the Choctawhatchee formation of Gully Sink, Washington County, Fla., is given here. No further specimens have been found.

\section{Genus MASSILINA Schlumberger, 1893}

Massilina marylandica Cushman and Cahill, n. sp.

Plate 2, Figures 9a-c

Test much compressed, periphery rounded; chambers distinct, especially the later ones, which gradually become developed in one plane; sutures distinct, depressed; wall ornamented by numerous longitudinal costae, nearly parallel to the periphery of the chamber; aperture not projecting but with a distinct tooth, which projects beyond the outline of the aperture. Length $1.00 \mathrm{~mm}$; breadth $0.70-0.75 \mathrm{~mm}$; thickness $0.15 \mathrm{~mm}$.

Holotype (No. 371739, U.S.N.M.) from the Miocene St. Marys formation, station $1 / 903$, about 1 mile above site of Langley House, Langleys Bluff, Chesapeake Bay, St. Marys County, Md., just below the contact with the Pleistocene.

This species somewhat resembles Massilina obliquestriata Cushman and Valentine, described from off the California coast. The ornamentation in the Miocene form, however, follows closely the outline of the chamber, and the early coils are much less prominent than in the Recent form. This species is fairly common at the type locality but was not noted elsewhere.

\section{Massilina glutinosa Cushman and Cahill, n. sp.}

\section{Plate 2, Figures 10a-c}

Test much compressed, broad, periphery rounded, the apertural end somewhat projecting; chambers numerous, somewhat indistinct, nearly circular in transverse section; sutures indistinct; wall arenaceous, of fine angular fragments with much cement, the surface smoothly finished; aperture circular, projecting, with a slight lip and tooth. Length $0.60 \mathrm{~mm}$; breadth $0.42-0.45 \mathrm{~mm}$; thickness $0.10 \mathrm{~mm}$.

Holotype (No. 371734, U.S.N.M.) from the Choptank formation, station $1 / 752$, about $2 \frac{1}{2}$ miles below Governor Run, Chesapeake Bay, Calvert County, Md.; fossils taken from the most fossiliferous bed, which crops out 3 to 4 feet above the beach up to about 18 feet; from zone 17 of the Maryland Geological Survey.

This species also occurs at station $1 / 753,1$ mile above Governor Run, Chesapeake Bay, Calvert County, Md.; the lower bed of the Choptank formation, or zone 17 of the Maryland Geological Survey; the base of this bed is about 28 to 30 feet above the beach. 
This is close to some of the figures which have been referred to as Spiroloculina asperula Karrer, but it is not the same as Karrer's species, although they resemble each other in some respects.

Massilina mansfieldi Cushman and Cahill, n. sp.

Plate 2, Figures 11a-c

Test about twice as long as broad, much compressed, periphery broadly rounded; chambers distinct, nearly circular in transverse section; sutures distinct but very slightly depressed; wall smooth and polished; aperture large with a very slight rounded border. Length $1.00-1.10 \mathrm{~mm}$; breadth $0.60-0.65 \mathrm{~mm}$; thickness $0.18-0.20 \mathrm{~mm}$.

Holotype (No. 371735, U.S.N.M.) from the Yorktown formation, station $1 / 193$, about $1 \frac{1 / 4}{4}$ miles below Yorktown, half a mile below prominent projecting point seen from Yorktown, York River, York County, Va., from lower bed of fragmental series.

The species also occurs in the St. Marys formation of Maryland.

\section{Genus SIGMOILINA Schlumberger, $\mathbf{1 8 8 7}$}

\section{Sigmoilina tenuis (Czjzek)}

Plate 3, Figures 1a-c

Quinqueloculina tenuis Czjzek, Haidinger's Nat. Abhandl., vol. 2 , p. 149 , pl. 13, figs. 31-34, 1847.

Sigmoilina tenuis Chaster, Southport Soc. Nat. Sci. First Rept., p. 56, 1892.

Jones, Foraminifera of the Crag, pt. 2, p. 125, pl. 7, fig. 2, 1895.

Cushman, U. S. Nat. Mus. Bull. 103, p. 31, pl. 31, figs. 4a-c, 1918; Scripps Inst. Oceanography Bull., Tech. ser., vol. 1, p. 139, 1927; Florida Geol. Survey Bull. 4, p. 22, pl. 2, figs. 8a-c, 1930.

Cushman and Ponton, Florida Geol. Survey Bull. 9, p. 51, 1932.

Sigmoilina elliptica Galloway and Wissler, Jour. Paleontology, vol. 1, p. 39, pl. 7, fig. 2, 1927.

Test sigmoid, longer than broad, compressed; chambers narrow, rounded in transverse section, five or six visible on each side; sutures distinct, curved; wall smooth; aperture with a slight neck, rounded. Length $0.40 \mathrm{~mm}$; breadth $0.20 \mathrm{~mm}$; thickness $0.08 \mathrm{~mm}$.

This species was recorded as rare in the Choctawhatchee formation of Florida, and Bagg recorded it from the Choptank formation of Pawpaw Point, Md., as "Spiroloculina tenuis." It is rather widely distributed in the Miocene, occurring in Panama and in South America, as well as in the Pleistocene of California.

There is a single record for this species from the Eocene of France, but the other records are all from the Miocene to Recent.
Genus TRILOCULINA D'Orbigny, 1826

\section{Triloculina schreiberiana D'Orbigny}

Plate 3, Figures 2a-c

This species was recorded ${ }^{4}$ from Coes Mill, Liberty County, Fla., where it was rare. No further specimens were found in the collections from Florida, but it has occurred rarely in the Yorktown formation of Virginia and the Choptank formation of Maryland.

\section{Triloculina asperula Cushman}

Plate 3, Figure 3

Triloculina asperula Cushman, U. S. Geol. Survey Bull. 676, p. 72, pl. 30, fig. 3, 1918; Florida Geol. Survey Bull. 4, p. 23, pl. 1, fig. 13, 1930.

Test subcircular in side view; chambers tapering toward each end, irregularly roughened; sutures distinct; aperture with a simple tooth. Diameter 0.25 $\mathrm{mm}$.

This species was described from the Choctawhatchee formation at Coes Mill, Liberty County, Fla., but no further specimens have been found.

\section{Genu.s PYRGO Defrance, 1824}

\section{Pyrgo subsphaerica (D'Orbigny)}

Plate 3, Figures 4a-c

Biloculina subsphaerica D'Orbigny, in De la Sagra, Histoire physique, politique et naturelle de l'île de Cuba, Foraminifères, p. 162, pl. 3, figs. 25-27, 1839.

Cushman, U. S. Nat. Mus. Proc., vol. 59, p. 73, 1921; Carnegie Inst. Washington Pub. 311, p. 77, 1922; Pub. 344, p. 83, 1926.

Pyrgo subsphaerica Cushman, U. S. Nat. Mus. Bull. 104, pt. 6, p. 68 , pl. 18, figs. 1, 2, 1929; Florida Geol. Survey Bull. 4, p. 23, pl. 3, figs. 5 a-c, 1930.

Cushman and Ponton, Florida Geol. Survey Bull. 9, p. 56, 1932.

Test small, rotund, slightly longer than broad, somewhat broader than thick; chambers rounded, periphery rounded; sutures distinct, depressed, in side view showing a sinuous line concave toward the last-formed chamber near the aperture and concave toward the preceding chamber at the opposite end; wall smooth and polished; aperture broadly oval, with a somewhat flattened tooth with short lateral extensions at the tip only partly filling the aperture. Length, $0.50 \mathrm{~mm}$; breadth, $0.40 \mathrm{~mm}$; thickness, $0.35 \mathrm{~mm}$.

This species was recorded ${ }^{5}$ as Biloculina bulloides from the Choctawhatchee formation of Jackson Bluff, Leon County, Fla. It must be very rare, as no further specimens were found.

4 Cushman, J. A., U. S. Geol. Survey Bull. 676, p. 71, pl. 30, fig. 4, 1918. 5 Idem, p. 72 , pl. 31 , fig. 1 , 


\section{Family OPHTHALMIDIIDAE}

Subfamily CORNUSPIRINAE

Genus CORNUSPIRA Schultze, 1854

Cornuspira involvens (Reuss)

Plate 3, Figure 5

Operculina involvens Reuss, Akad. Wiss. Wien Denkschr., vol. 1, p. 370 , pl. 46 , fig. $30,1850$.

Cornuspira involvens Reuss, Akad. Wiss. Wien Sitzungsber., vol. 48, Abt. 1, p. 39, pl. 1, fig. 2, 1863.

Cushman, Florida Geol. Survey Bull. 4, p. 23, pl. 3, fig. $6,1930$.

Cushman and Ponton, Florida Geol. Survey Bull. 9, p. 57, 1932. [For complete references to this species, see Cushman, U.S. Nat. Mus. Bull. 104, pt. 6, p. 80, 1929.]

Test nearly circular in side view, consisting of a proloculum and a long, closely coiled, planispiral second chamber of nearly equal diameter throughout, slightly involute; sutures distinct, somewhat depressed; wall smooth and polished, occasionally showing slight lines of growth; aperture nearly the size of the open end of the tube.

The only records for this species from the Miocene of this region are a single specimen from Jackson Bluff, on the left bank of the Ochlockonee River, just above the bridge, Leon County, Fla., and specimens from stations in the typical Chipola of Florida.

The species is a common one in warm shallow waters of the West Indies, a fact which probably explains its absence in the Miocene of the area north of Florida, where no specimens were obtained in all material examined.

\section{Family LAGENIDAE \\ Subfamily NODOSARIINAE \\ Robulus americanus (Cushman) \\ Plate 3, Figures $6 a, b$}

Cristellaria americana Cushman, U. S. Geol. Survey Bull. 676, p. 50 , pl. 10, figs. $5,6,1918$.

Robulus americanus Cushman, Florida Geol. Survey Bull. 4, p. 24, pl. 3, figs. 7a, b, 1930.

R. E. and K. C. Stewart, Am. Assoc. Petroleum Geologists Bull., vol. 14, p. 1448, 1930.

Cushman and Ponton, Florida Geol. Survey Bull. 9, p. 58, 1932.

Test closely coiled, biconvex, slightly keeled, composed of but six or seven chambers in the last-formed whorl; sutures raised and ending in a raised umbonal area, surface otherwise smooth; aperture radiate, with the median ventral slit enlarged and prolonged into the apertural face. Diameter up to $1.50 \mathrm{~mm}$; thickness up to $0.75 \mathrm{~mm}$.

This species is cornmon in the Choctawhatchee formation of Florida and occurs also in two of the members of the Shoal River formation. The species may be distinguished by its closely coiled form with com- paratively few chambers, the raised costae, and the raised umbonal area. It occurs also at a single station in South Carolina.

Robulus americanus (Cushman) var. spinosus (Cushman)

Plate 3, Figures $7 \mathrm{a}, \mathrm{b}$

Cristellaria americana Cushman var. spinosa Cushman, U. S. Geol. Survey Bull. 676, p. 51, pl. 10, fig. 7, 1918.

Robulus americanus (Cushman) var. spinosus Cushman. Stewart and Stewart, San Diego Soc. Nat. Hist. Trans., vol. 6 , p. 53, pl. 8, fig. 2, 1930.

Cushman, Florida Geol. Survey Bull. 4, p. 24, pl. 3, figs. $8 \mathrm{a}, \mathrm{b}, 1930$.

R. E. and K. C. Stewart, Am. Assoc. Petroleum Geologists Bull., vol. 14, p. 1448, 1930.

Cushman and Ponton, Florida Geol. Survey Bull. 9, p. 58, 1932.

Variety differing from the typical form by the addition of spines on the peripheral margin opposite the ends of the sutures.

This variety occurs with the typical form in the Choctawhatchee and Shoal River formations of Florida. To the north it also occurs very rarely in the Miocene of North Carolina. The variety is also recorded from the late Tertiary of California.

\section{Robulus iotus (Cushman)}

Plate 4 , Figures 1a, b

Cristellaria cultrata H. B. Brady (not Montfort), Challenger Rept., Zoology, vol. 9, p. 550, pl. 70, figs. 4-6, 1884.

Cristellaria iota Cushman, U. S. Nat. Mus. Bull. 104, pt. 4 , p. 111, pl. 29, fig. 2; pl. 30, fig. 1, 1923.

Robulus iotus Cushman, Florida Geol. Survey Bull. 4, p. 25 , pl. 4, figs. 1a, b, 1930.

Cushman and Ponton, Florida Geol. Survey Bull. 9, p. 58, 1932.

Test close-coiled, compressed, umbonate, the periphery with a thin, broad keel, nearly transparent, 10 to 15 chambers in the last-formed coil in the adult, narrow; sutures slightly curved, slightly limbate, but not raised above the general surface, umbonal region occupied by a large, thickened, transparent knob; wall smooth, thin; aperture radiate, at the peripheral angle of the test with the ventral slit continued in to the apertural face. Diameter of Florida specimens up to $1.5 \mathrm{~mm}$.

The only specimens of this species from the Miocene of the eastern United States are from stations in the Choctawhatchee and Shoal River formations of Florida.

\section{Robulus floridanus (Cushman) \\ Plate 4, Figures 2a, b}

Cristellaria floridana Cushman, U. S. Geol. Survey Bull. 676, p. 51 , pl. 11, fig. 1,1918 .

Robulus floridanus Cushman, Florida Geol. Survey Bull. 4, p. 25, pl. 4. figs. 2a, b, 1930.

Cushman and Ponton, Florida Geol. Survey Bull. 9, p. 58, 1932. 
Test elongate, crosier-form, early portion closely coiled, later chambers becoming uncoiled and more elongate, test comparatively thick in front view, peripheral margin rounded; wall smooth, except for slightly raised areas above the sutures, which are otherwise indistinct; aperture peripheral. Length 2.00 $\mathrm{mm}$; breadth $1.20 \mathrm{~mm}$; thickness $0.50 \mathrm{~mm}$.

The type of this species is from the Choctawhatchee formation, 1 mile south of Red Bay, Walton County, Fla.

A single specimen, which seems to be the early stage of this species, before the uncoiling takes place, came from the Choptank formation of Maryland.

\section{Robulus catenulatus (Cushman)}

Plate 4, Figures $3 \mathrm{a}, \mathrm{b}$

Cristellaria catenulata Cushman, U. S. Geol. Survey Bull. 676, p. 51, pl. 11, fig. 2, 1918.

Robulus catenulatus Cushman, Florida Geol. Survey Bull. 4, p. 25, pl. 4, figs. 3a, b, 1930.

Cushman and Ponton, Florida Geol. Survey Bull. 9, p. 58, 1932.

Test comparatively large, compressed, oval, composed of numerous chambers, 10 or more in the lastformed coil, peripheral margin narrowed but rounded, the area above the sutures with broad, raised ribs curving toward the umbilical region, the inner ends often terminating in rounded knobs or the whole suture with a row of beadlike prominences; aperture radiate, slightly projecting. Diameter of type 2.00 $\mathrm{mm}$.

The only records for this species are from Walton County, Fla., where it seems to be rare. It is evidently a variable species; as noted in the Florida report, it very strongly resembles Robulus vaughani (Cushman), from the Miocene of the Panama Canal Zone, and the two may be identical.

\section{Genus PLANULARIA Defrance, 1824}

Planularia sp.?

Plate 4, Figures $4 \mathrm{a}$, b

Planularia sp.? Cushman, Florida Geol. Survey Bull. 4, p. 26, pl. 4, figs. 6a, b, 1930 .

No additional specimens of this particular form, which was figured from Walton County, Fla., have been found in any of the material examined from the States to the north.

\section{Planularia sp.?}

Plate 4 , Figures $5 \mathrm{a}, \mathrm{b}$

Planularia sp.? Cushman, Florida Geol. Survey Bull. 4, p. 26, pl. 4, figs. 4a, b, 5, 1930 .

The specimens figured from Gully Sink, Washington County, Fla., have not been added to by our study of material from the other collections. Therefore, this form must remain unidentified until additional specimens which show the adult characters are found.

\section{Genus MARGINULINA D'Orbigny, 1826}

\section{Marginulina sp.?}

Plate 4, Figures 6a, b

Marginulina sp.? Cushman, Florida Geol. Survey Bull. 4, p. 26, pl. 4 , figs. $7 \mathrm{a}, \mathrm{b}, 1930$.

The specimen figured is from the Choctawhatchee formation of Florida from a cut in the road leading to Watson's Landing, Liberty County. No additional specimens have been noted in our further studies.

\section{Marginulina dubia Neugeboren}

Plate 4, Figures 7a, b

Marginulina dubia Neugeboren, Siebenbürg. Ver. Naturwiss. Verh. u. Mitt., vol. 2, p. 120, pl. 4, fig. 1, 1851; Akad. Wiss. Wien Denkschr., vol. 12, p. 100, 1856.

Cushman and Laiming, Jour. Paleontology, vol. 5, p. 98, pl. 10, fig. 7, 1931.

Cushman and Parker, Contr. Cushman Lab. Foram. Research, vol. 7, p. 3, pl. 1, fig. 6, 1931.

Cushman and Ponton, Florida Geol. Survey Bull. 9, p. 59, pl. 8, figs. 11a, b, 1932.

Marginulina sp.? Cushman, Florida Geol. Survey Bull. 4, p. 27, pl. 4, figs. 8a, b, 1930 .

From material recently studied from the Miocene of California, it would seem that the figured specimen, which came from the upper fossiliferous bed at Alum Bluff, Apalachicola River, Liberty County, Fla., may be possibly identified as Marginulina dubia Neugeboren. The early portion is more closely coiled than in the California specimens, but the general shape and appearance of the last-formed chambers are very much alike in the two forms.

\section{Marginulina sp.?}

Plate 4, Figures $8 \mathrm{a}, \mathrm{b}$

Marginulina sp.? Cushman, Florida Geol. Survey Bull. 4, p. 27, pl. 4, figs. 9 a, b, 1930.

This somewhat irregular form, which was found in the Choctawhatchee formation in the lowest fossiliferous bed on Jim Kennedy Branch, about 1 mile east of Red Bay, Walton County, Fla., has not been found again in any of our more recently collected material.

\section{Genus SARACENARIA Defrance, 1824}

\section{Saracenaria acutauricularis (Fichtel and Moll)}

Plate 5, Figures $1 \mathrm{a}, \mathrm{b}$

"Hammoniae subrotundae" Soldani, Testaceographia, vol. 1, pt. 1 , p. 61 , pl. 49 , fig. X, 1789.

Nautilus acutauricularis Fichtel and Moll, Testacea microscopica, p. 102, pl. 18, figs. g-i, 1803.

Cristellaria acutauricularis Parker and Jones, Annals and Mag. Nat. Hist., 3d ser., vol. 5, p. 114, 1860.

H. B. Brady, Challenger Rept., Zoology, vol. 9, p. 543, pl. 114, figs. 17 a, b, 1884 .

Saracenaria acutauricularis Cushman, Florida Geol. Survey Bull. 4, p. 27, pl. 4, figs. 10 a, b, 1930.

Cushman and Ponton, Florida Geol. Survey Bull. 9, p. 60, 1932. 
This species was found in the Choctawhatchee formation in the lower bed on Jim Kennedy Branch, about 1 mile east of Red Bay, Walton County, Fla. It also occurs in beds of the Shoal River formation of Florida. The species has also been recorded from the Miocene of Trinidad and Venezuela.

There are Jurassic records for this species, but the figures given for them indicate that the Jurassic forms are not identical with the species of later formations.

\section{Genus DENTALINA D'Orbigny, 1826}

Dentalina communis D'Orbigny

Plate 5, Figure 2

Nodosaria (Dentalina) communis D'Orbigny, Annales sci. nat., vol. 7 , p. 254 , No. $35,1826$.

Cushman, Florida Geol. Survey Bull. 4, p. 27, pl. 5, fig. 1, 1930.

Cushman and Ponton, Florida Geol. Survey Bull. 9, p. 60, 1932.

Nodosaria communis Reuss, Die Versteinerungen der böhmischen Kreideformation, pt. 1, p. 28, pl. 12, fig. 21, 1845. [For further references to this species, see Cushman, U. S. Nat. Mus. Bull. 104, pt. 6, p. 75, 1929.]

Test elongate, slender, slightly tapering, slightly curved, composed of several chambers, those toward the apertural end inflated; sutures depressed, those toward the initial end less distinct, more or less oblique; wall smooth; aperture radiate, excentric. Length up to $3.00 \mathrm{~mm}$.

This species is rather widely distributed in the Miocene, being recorded from the Choctawhatchee and Shoal River formations of Florida. A single specimen, apparently this same species, occurs in material from the Yorktown formation in Virginia. The species also occurs in the Miocene Gatun formation of the Panama Canal Zone and has recently been recorded from the Temblor formation of California. ${ }^{6}$ There are also Jurassic records given for this species, but it is questionable whether or not they represent D'Orbigny's species.

\section{Dentalina consobrina D'Orbigny var. emaciata Reuss}

\section{Plate 5, Figure 3}

Dentalina emaciata Reuss, Deutsche geol. Gesell. Zeitschr., vol. 3 , p. 63 , pl. 3 , fig. $9,1851$.

Nodosaria (Dentalina) consobrina var. emaciata Reuss, Akad. Wiss. Wien Denkschr., vol. 25, p. 132, pl. 2, figs. 12, 13, 1865.

H. B. Brady, Challenger Rept., Zoology, vol. 9, p. 502, pl. 62, figs. 25, 26, 1884.

Flint, U. S. Nat. Mus. Rept. for 1897, p. 310, pl. 56, fig. 1, 1899.

Cushman, U. S. Nat. Mus. Bull. 71, pt. 3, p. 56, pl. 27, fig. 9, 1913; Bull. 104, pt. 4, p. 78, pl. 13, figs. 3-5, 1923; Florida Geol. Survey Bull. 4, p. 28, pl. 5, fig. 2, 1930.

Cushman and Ponton, Florida Geol. Survey Bull. 9, p. 61, 1932.

${ }^{6}$ Cushman, J. A., and Parker, F. L., Contr. Cushman Lab. Foram. Research, vol. 7 , p. 3, pl. 1, fig. 8,1931 .
Test elongate, tapering, often with a spine at the apical end, slightly curved; composed of numerous chambers, short and cylindrical in the early portion but becoming longer and more inflated in the later portion; sutures not depressed in the early portion, more so later; wall smooth; aperture radiate, slightly excentric.

This seems to be a very rare form in the Miocene of the eastern portion of the United States. The figured specimen is from the Choctawhatchee formation of Florida, from the lowest fossiliferous bed on Jim Kennedy Branch, about 1 mile east of Red Bay, Walton County. It occurs rarely in the Choctawhatchee and Shoal River formations of Florida. We have a single broken specimen, showing the last-formed chambers, from the Yorktown formation of Virginia, which it seems may be placed under this name.

\section{Dentalina sp.?}

Plate 5, Figure 4

Dentalina sp.? Cushman, Florida Geol. Survey Bull. 4, p. 28, pl. 5, fig. 3, 1930.

This figured fragment was found with the abovedescribed form in Florida, but no further specimens were obtained in the other material examined from the States to the north. Later material from the Miocene of Florida seems to show that this should be referred to Dentalina pyrula (D'Orbigny). ${ }^{6 a}$

\section{Genus NODOSARIA Lamarck, 1812}

\section{Nodosaria catesbyi D’Orbigny}

Plate 5, Figure 5

Nodosaria catesby $i$ D'Orbigny, in De la Sagra, Histoire physique, politique et naturelle de l'île de Cuba, Foraminifères, p. 16, pl. 11, figs. 8-10, 1839 .

Cushman, Florida Geol. Survey Bull. 4, p. 28, pl. 5, fig. 4, 1930.

Cushman and Ponton, Florida Geol. Survey Bull. 9, p. 61, 1932.

Test composed of two chambers, the proloculum subglobular, with a short basal spine, the second chamber more pyriform, apertural end somewhat prolonged; suture distinct and depressed; wall ornamented with numerous very distinct costae, which extend the entire length of the two chambers to the aperture. Length $0.45 \mathrm{~mm}$; diameter $0.17 \mathrm{~mm}$.

The figured specimen is from the Choctawhatchee formation of Florida, where the species occurs in Calhoun, Liberty, and Leon Counties. This is evidently the same species that D'Orbigny had from Recent material off the West Indies, where it is widely distributed but never occurs in any considerable numbers so far as material we have studied shows.

6a Cushman and Ponton, Florida Geol. Survey Bull. 9, p. 61, pl. 9, figs, 5, 6,1932. 


\section{Subfamily LAGENINAE}

\section{Genus LAGENA Walker and Jacob, 1798}

\section{Lagena perlucida (Montagu)}

Plate 5, Figures 6a, b

Vermiculum perlucidum Montagu, Testacea Britannica, p. 525, pl. 14, fig. 3, 1803 .

Lagena perlucida Brown, Illustrations of the conchology of Great Britain and Ireland, fly leaf, pl. 1, fig. 29, 1827; 2 d ed., p. 3, pl. 56, fig. 29, 1844.

Schlumberger, Feuille des jeunes naturalistes, ann. 12, pl. 1, fig. 2, 1882.

Cushman, U. S. Nat. Mus. Bull. 104, pt. 4, p. 46, pl. 8 , figs. 12, 13, 1923; Florida Geol. Survey Bull. 4, p. 29, pl. 5, fig. 5, 1930.

Cushman and Parker, Contr. Cushman Lab. Foram. Research, vol. 7, p. 6, pl. 1, fig. 22, 1931.

Cushman and Ponton, Florida Geol. Survey Bull. 9, p. 62 , 1932.

Lagena vulgaris Williamson var. perlucida Williamson, Recent Foraminifera of Great Britain, p. 5, pl. 1, figs. 7, 8, 1858.

Test somewhat pyriform, elongate, broadest near the base, the apertural end continued into an elongate, cylindrical, slender neck, often with a slight lip, the opposite portion of the test with a few, fine, longitudinal costae, extending part way up the body of the test; surface otherwise smooth. Length up to 0.30 $0.35 \mathrm{~mm}$; diameter $0.10-0.15 \mathrm{~mm}$.

This species has already been recorded from the Miocene Choctawhatchee formation of several counties in Florida. Later material shows that it also occurs in the Shoal River, Oak Grove, and Chipola of the Florida Miocene. It has also been recently recorded from the Miocene Temblor formation of California. The only specimens in our material came from the Yorktown formation of North Carolina and the Calvert formation of Chesapeake Beach, Md.

There is a considerable variation in the shape of the test of this species.

\section{Lagena clavata (D’Orbigny)}

\section{Plate 5, Figures 7a, b}

Oolina clavata D'Orbigny, Foraminifères fossiles du bassin tertiaire de Vienne, p. 24, pl. 1, fig. 2, 1846.

Lagena clavata Mackie, Recreative science, vol. 1, p. 148, fig. 13, 1859.

Cushman, Florida Geol. Survey Bull. 4, p. 29, pl. 5, figs. 6a, b, 1930.

Cushman and Ponton, Florida Geol. Survey Bull. 9, p. 62, 1932. [For complete references to this species, see Cushman, U. S. Nat. Mus. Bull. 104, pt. 4, p. 10, 1923.]

Test elongate, clavate or fusiform, with a long neck at the oral end and basal end rounded, usually with a spinose projection, transverse section circular; wall smooth, thin, and transparent; aperture with a definite phialine lip. Length $0.30-0.40 \mathrm{~mm}$; diameter $0.15-$ $0.18 \mathrm{~mm}$.

This species occurs rarely in the Choctawhatchee formation of Florida, and we have it also from the $136785^{\circ}-33-2$
Miocene Choptank and Calvert formations of Maryland. The few records from the Eocene and Cretaceous may not be of forms identical with the species so common from the Miocene to the Recent seas.

\section{Lagena hexagona (Williamson)}

Plate 5, Figures 8a, b

Entosolenia squamosa Montagu var. hexagona Williamson, Annals and Mag. Nat. Hist., 2d ser., vol. 1, p. 20, pl. 2, fig. 23, 1848; Recent Foraminifera of Great Britain, p. 13, pl. 1, fig. 31, 1858.

Lagena hexagona Siddall, Catalogue of Recent British Foraminifera, p. 6, 1879 .

Cushman, Florida Geol. Survey Bull. 4, p. 30, pl. 5, figs. 11a, b, 1930.

Cushman and Ponton, Florida Geol. Survey Bull. 9, p. 62, 1932. [For complete references to this species, see Cushman, U. S. Nat. Mus. Bull. 104, pt. 4, p. 24, 1923.]

Test pyriform, base semicircular, apertural end somewhat drawn out, with a short neck; surface ornamented by rather regular, hexagonal reticulations. Length up to $0.30 \mathrm{~mm}$; diameter $0.20 \mathrm{~mm}$.

This species is rare in the Choctawhatchee, Shoal River, and Chipola formations of Florida, but no further records can be added from our study of the material northward to Maryland.

Lagena hexagona (Williamson) var. scalariformis (Williamson)

Plate 5, Figures 9a, b

Entosolenia squamosa (Montagu) var. scalariformis Williamson, Recent Foraminifera of Great Britain, p. 13, pl. 1, fig. $30,1858$.

Lagena scalariformis Reuss, Akad. Wiss. Wien Sitzungsber., vol. 46 , pt. 1 , p. 333, pl. 5, figs. 69-71, 1862 (1863).

Lagena hexagona (Williamson) var. scalariformis Cushman, U. S. Nat. Mus. Bull. 71, pt. 3, p. 17, pl. 6, fig. 4, 1913; Scripps Inst. Oceanography Bull., Tech. ser., vol. 1, p. 145, 1927; Contr. Cushman Lab. Foram. Research, vol. 5, pt. 3, p. 72 , pl. 11, fig. 17, 1929; Florida Geol. Survey Bull. 4, p. 30, pl. 5, figs. 7a, b, 1930.

Cushman and Parker, Contr. Cushman Lab. Foram. Research, vol. 7, p. 7, pl. 1, fig. 24, 1931.

Cushman and Ponton, Florida Geol. Survey Bull. 9, p. 62, 1932.

Test subglobular, surface ornamentation of generally reticulate pattern, the sides of the reticulations often thickened, forming costae, the top and bottom borders usually less conspicuous; aperture without a neck or lip, slightly protruding. Length $0.25 \mathrm{~mm}$; diameter $0.18 \mathrm{~mm}$.

Although this is one of the commonest forms of the genus in the Choctawhatchee formation of Florida, where it occurs in Bay, Calhoun, Leon, Liberty, and Washington Counties, no further records were obtained from our studies of the additional collections.

This variety has recently been recorded from the Miocene Temblor formation of California. 


\section{Lagena sulcata (Walker and Jacob)}

\section{Plate 5, Figure 10}

"Serpula (Lagena) striata sulcata rotundata" Walker and Boys Testacea minuta rariora, p. 2, pl. 1, fig. 6, 1784.

Serpula (Lagena) sulcata Walker and Jacob, in Adam's Essays on the microscope, Kanmacher's ed., p. 634, pl. 14, fig. 5, 1798.

Lagena sulcata Parker and Jones, Philos. Trans., vol. 155, p. 351, 1865.

Cushman, Florida Geol. Survey Bull. 4, p. 31, pl. 5, fig. 10, 1930.

Cushman and Parker, Contr. Cushman Lab. Foram. Research, vol. 7, p. 6, pl. 1, fig. 20, 1931.

Cushman and Ponton, Florida Geol. Survey Bull. 9, p. 63, 1932.

Test typically subglobose, slightly longer than broad; wall with numerous, rather coarse, longitudinal costae, neck elongate with a definite, phialine lip. Length of figured specimen $0.27 \mathrm{~mm}$; diameter $0.18 \mathrm{~mm}$.

This very common and widely distributed species seems to be rare in the American Miocene. Single specimens occurred in Florida at Darlings Slide, about $2 \frac{1}{2}$ miles southeast of Clarksville, Calhoun County, and in the upper fossiliferous bed at Alum Bluff, Apalachicola River, Liberty County. It has recently been recorded also from the Miocene Temblor formation of California.

There are a few records from the Jurassic citing this species, but most of them do not seem to be of identical forms.

\section{Lagena substriata Williamson}

Plate 5, Figures 11a, b

Lagena substriata Williamson, Annals and Mag. Nat. Hist., $2 \mathrm{~d}$ ser., vol. 1, p. 15 , pl. 1, fig. 12, 1848 .

Cushman, U. S. Nat. Mus. Bull. 104, pt. 4, p. 56, pl. 10 , fig. 11, 1923; Scripps Inst. Oceanography Bull., Tech. ser., vol. 1, p. 145, 1927; Contr. Cushman Lab. Foram. Research, vol. 5, p. 68, pl. 11, fig. 4, 1929; Florida Geol. Survey Bull. 4, p. 31, pl. 5, fig. 14, 1930.

Cushman and Ponton, Florida Geol. Survey Bull. 9, p. 63, 1932.

Lagena vulgaris Williamson var. substriata Williamson, Recent Foraminifera of Great Britain, p. 7, pl. 1, fig. 14, 1858.

Test elongate, body of the test longer than broad, basal end rounded, apertural end tapering into an elongate neck; wall ornamented with numerous fine longitudinal costae, continuous from the base of the chamber to the neck, sometimes a few on the neck itself. Length $0.40-0.50 \mathrm{~mm}$; diameter $0.25-0.30 \mathrm{~mm}$.

This species has already been recorded from the Choctawhatchee formation of Walton, Liberty, Leon, and Calhoun Counties, Fla., and from one station in the Shoal River formation. In our material are specimens from the St. Marys and Calvert formations of Maryland and from the Yorktown formation of North Carolina.

\section{Lagena costata (Williamson) var. amphora Reuss}

\section{Plate 5, Figure 14}

Lagena amphora Reuss, Akad. Wiss. Wien Sitzungsber., vol. 46, pt. 1, p. 330, pl. 4, fig. 57, 1862 (1863).

Lagena costata (Williamson) var. amphora Cushman, U. S. Nat. Mus. Bull. 71 , pt. 3, p. 21, pl. 10, figs. 2, 3; pl. 12, fig. 2, 1913; Contr. Cushman Lab. Foram. Research, vol. 5, p. 70 , pl. 11, figs. 11, 12, 1929; Florida Geol. Survey Bull. 4, p. 31, pl. 5, fig. 8, 1930.

Cushman and Ponton, Florida Geol. Survey Bull. 9, p. 63, 1932.

Test elongate, pyriform, with a long, tapering neck; surface with comparatively few, prominent costae, running up onto the elongate tapering neck; aperture small, without a lip. Length of figured specimen 0.27 $\mathrm{mm}$; diameter $0.12 \mathrm{~mm}$.

The only Miocene references from eastern United States are those already recorded from Florida. This form also occurs in the Calvert formation of Chesapeake Beach, Md.

\section{Lagena cf. L. striato-punctata Parker and Jones}

\section{Plate 5, Figure 13}

Several specimens from the lower bed at Alum Bluff, on the Apalachicola River, Liberty County, Fla., similar to that here figured are recorded under this name in the bulletin on the Choctawhatchee formation of Florida. ${ }^{7}$

Lagena orbignyana (Seguenza) var. lacunata Burrows and Holland

\section{Plate 5, Figures 12a, b}

Lagena castrensis H. B. Brady (not Schwager), Challenger Rept., Zoology, vol. 9, p. 485, pl. 60, figs. 1, 2, 1884.

Balkwill and Wright, Roy. Irish Acad. Trans., vol. 28 (Sci.), p. 341, pl. 12, figs. 20, 21, 1885.

Egger, K.-bayer. Akad. Wiss. München, Cl. 2, Abh., vol. 18 , p. 333 , pl. 10 , figs. $71,72,1893$.

Flint, U. S. Nat. Mus. Rept. for 1897, p. 308, pl. 54, fig. 5, 1899.

Lagena lacunata Burrows and Holland, in Jones, Foraminifera of the Crag, p. 205, pl. 7, fig. 12, 1895.

Lagena orbignyana var. castrensis Millett, Roy. Micr. Soc. Jour., 1901, p. 626, pl. 14, fig. 20.

Lagena orbignyana var. lacunata Sidebottom, Manchester Lit. Philos. Soc. Mem. and Proc., vol. 54, No. 16, p. 19, pl. 2, fig. 14, 1910; Quekett Mier. Club Jour., vol. 11, p. 416, pl. 19, figs. 16-18, 1912.

Cushman, U. S. Nat. Mus. Bull. 71 , pt. 3, p. 43, pl. 20, fig. 1, 1913; Florida Geol. Survey Bull. 4, p. 32, pl. 5, figs. 13a, b, 1930.

Cushman and Ponton, Florida Geol. Survey Bull. 9, p. 63, 1932.

Test rounded or ovate, much compressed, whole test surrounded by a peripheral keel, inside of which on each side is a complete raised rim about the body proper; neck somewhat elongate; wall with the body

\footnotetext{
7 Cushman, J. A., Florida Geol. Survey Bull. 4, p. 32, pl. 5, fig. 9, 1930.
} 
portion ornamented by a network of lacunae or pitted areas of varying size, usually with an outlining ring about each pit. Length up to $0.30 \mathrm{~mm}$; breadth 0.25 $\mathrm{mm}$; thickness $0.15 \mathrm{~mm}$.

Although this form occurs rather abundantly in the Choctawhatchee formation of Florida, being recorded from Leon, Liberty, and Washington Counties, no specimens were found in all the numerous collections studied from localities north of this area.

\section{Lagena cf. L. marginato-perforata (Seguenza)}

Plate 5, Figures 15a, b

In the Choctawhatchee formation specimens from Liberty and Leon Counties, Fla., were referred to this species. Similar specimens occur in the Shoal River and Oak Grove of Florida. The specimen here figured came from the Yorktown formation of Virginia, and additional specimens occurred at one other station in the Yorktown of North Carolina. The test is much compressed, of distinctive form, with a very variable keel, but the surface is always coarsely perforate.

\section{Family POLYMORPHINIDAE Genus GUTTULINA D'Orbigny, 1826 Guttulina irregularis (D'Orbigny)}

Globulina irregularis D'Orbigny, Foraminifères fossiles du bassin tertiaire de Vienne, p. 226, pl. 13, figs. 9, 10, 1846.

Cushman and Thomas, Jour. Paleontology, vol. 3, p. 177, pl. 23, figs. 2a-c, 1929.

Guttulina irregularis Cushman, Florida Geol. Survey Bull. 4, p. 33, 1930.

Cushman and Ponton, Florida Geol. Survey Bull. 9, p. 64, pl. 9, figs. 10-12, 1932. [For further references, see Cushman and Ozawa, U. S. Nat. Mus. Proc., vol. 77, art. 6,1930 .]

Test oval to subdeltoidal, equilaterally triangular, with rounded sides and angles, except the acute apertural end; chambers more or less angular, elongated, arranged in a clockwise, quinqueloculine series, each succeeding chamber except the last one or two in fullgrown specimens coming down to the base; sutures depressed, distinct; wall smooth but in full grown specimens often having the last small chamber with spines or covered with fistulose tubes; aperture radiate.

Although this species is very widely distributed in the Tertiary and especially in the Oligocene of America, it is strange that there are so few records from the Miocene of the eastern part of the United States. It is rare in the Choctawhatchee formation of Florida but is common in the Shoal River and Chipola formations.

\section{Guttulina costatula Galloway and Wissler}

$$
\text { Plate 6, Figures 1a, b }
$$

Polymorphina (Guttulina) costatula Galloway and Wissler, Jour. Paleontology, vol. 1, p. 57, pl. 9, figs. 10a, b, 1927.

Guttulina costatula Cushman and Ozawa, U. S. Nat. Mus. Proc., vol. 77 , art. 6 , p. 35 , pl. 6 , figs. $3 \mathrm{a}, \mathrm{b}, 1930$.

Cushman, Florida Geol. Survey Bull. 4, p. 33, pl. 5, fig. 15, 1930.
Test short, somewhat fusiform, acute at both ends; chambers inflated, rounded, not much embracing, arranged in a contraclockwise, quinqueloculine series, each succeeding chamber removed much farther from the base; sutures depressed, distinct; wall ornamented with numerous distinct, rounded costae, of which there are five more strongly developed at the base, radiating from the acute initial end independent of the sutures, and taking positions in accord with the quinqueloculine arrangement of the early chambers; aperture produced, radiate.

In Florida this species has been recorded from the Choctawhatchee formation at numerous stations but not in the lower Miocene. We have additional material from the Duplin marl of South Carolina.

Guttulina lactea (Montagu) var. earlandi Cushman and Ozawa

Plate 6, Figure 2

Polymorphina concava Jones (not Williamson), Foraminifera of the Crag, pt. 3, p. 264, pl. 5, fig. 22, 1896.

Heron-Allen and Earland, Roy. Micr. Soc. Jour., 1909, p. 431 , pl. 17 , fig. 6 .

Polymorphina lactea var. concava Sidebottom, Manchester Lit. Philos. Soc. Mem. and Proc., vol. 51, No. 9, p. 14, pl. 3, figs. 8, 9, 1907.

Guttulina lactea (Montagu) var. earlandi Cushman and Ozawa, U. S. Nat. Mus. Proc., vol. 77, art. 6, p. 45, pl. 10, fig. 5, 1930.

Cushman, Florida Geol. Survey Bull. 4, p. 34, pl. 5, fig. 19, 1930.

Cushman and Ponton, Florida Geol. Survey Bull. 9, p. 65, 1932.

This variety differs from the typical form of the species in its attached character and in holding to the short form seen in the early stages of the typical form.

The single specimen previously recorded from Florida from the Choctawhatchee formation of Gully Sink, T. 2 N., R. 14 (?) W., Washington County, has now been supplemented by rare occurrences in that formation and in the Shoal River formation of Florida.

\section{Guttulina austriaca D'Orbigny}

Plate 6, Figures 3, 4

Guttulina austriaca D'Orbigny, Foraminifères fossiles du bassin tertiaire de Vienne, p. 223, pl. 12, figs. 23-25, 1846.

Terquem, Soc. géol. France Mém., sér. 3, vol. 2, p. 133, pl. 13 (21), fig. 36, 1882.

Cushman and Ozawa, U. S. Nat. Mus. Proc., vol. 77, art. 6, p. 29, pl. 4, figs. 3-5, 1930.

Cushman and Ponton, Florida Geol. Survey Bull. 9, p. 65, pl. 9, figs. 13, 14, 1932 .

Polymorphina oblonga D'Orbigny, op. cit., p. 232, pl. 12, figs. 29-31, 1846.

Terquem, op. cit., p. 145, pl. 15 (23), fig. 9, 1882.

H. B. Brady, Challenger Rept., Zoology, vol. 9, p. 569, pl. 73, fig. 4 (not figs. 2 and 3), 1884.

Chaster, Southport Soc. Nat. Sci. First Rept., p. 64, pl. 1, fig. 13, 1892.

Bagg, U. S. Geol. Survey Bull. 513, p. 73, pl. 20, figs. 10-12, 1913.

Cushman, U. S. Nat. Mus. Bull. 71, pt. 3, p. 88, pl. 37, fig. 6,1913 ; Bull. 100, vol. 4, p. 268, pl. 52, fig. 3, 1921. 
Polymorphina guttata Reuss, Akad. Wiss. Wien Sitzungsber., vol. 62 , pt. 1, p. $487,1870$.

Von Schlicht, Die Foraminiferen des Septarienthones von Pietzpuhl, pl. 30, figs. 25-32, 1870.

Test fusiform to oblong, more or less rounded at the base, rather acute at the apertural end, often botryoidal, greatest breadth usually above the middle; chambers oval to clavate, slightly embracing, arranged in a clockwise, quinqueloculine series, each succeeding chamber removed much farther from the base; sutures depressed and very distinct; wall smooth, translucent; aperture produced, radiate. Length $0.60-1.15 \mathrm{~mm}$; breadth $0.40-0.55 \mathrm{~mm}$; thickness $0.35-0.50 \mathrm{~mm}$.

This species was found rarely in the Choctawhatchee formation of Florida and occurs rather rarely in the St. Marys and Yorktown formations of Virginia.

Genus PYRULINA D'Orbigny, 1826

Pyrulina albatrossi Cushman and Ozawa

Plate 6, Figures 5a, b

Pyrulina albatrossi Cushman and Ozawa, U. S. Nat. Mus. Proc., vol. 77 , art. 6 , p. 58, pl. 15, figs. 1-3, 1930.

Cushman, Florida Geol. Survey Bull. 4, p. 34, pl. 5, figs. $17,18,1930$.

Cushman and Ponton, Florida Geol. Survey Bull. 9, p. 66, 1932.

Test elongate, fusiform to cylindrical, acute at both ends; chambers elongated, much embracing, arranged in a triserial series, becoming biserial later, but often one extra, rounded chamber added at the top of the test, each succeeding chamber slightly removed from the base; sutures but little depressed, nearly vertical, generally distinct; wall smooth, thin, almost transparent; aperture radiate. Length $0.65 \mathrm{~mm}$; diameter $0.30 \mathrm{~mm}$.

This species, originally described from Recent material from the western Atlantic, has also been recorded from the Miocene Choctawhatchee formation of Florida. In the collections recently studied rather typical specimens occur in the Choptank and Calvert formations of Maryland and in the Yorktown formation of North Carolina.

\section{Genus GLOBULINA D'Orbigny, 1826}

\section{Globulina gibba D'Orbigny}

Plate 6, Figure 6

Globulina gibba D'Orbigny, Annales sci. nat., vol. 7, p. 277, No* 10, Modèles, No. 63, 1826; Foraminifères fossiles du bassin tertiaire de Vienne, p. 227, pl. 13, figs. 13, 14, 1846.

Cushman, Florida Geol. Survey Bull. 4, p. 34, pl. 5, fig. 21, 1930.

Cushman and Ponton, Florida Geol. Survey Bull. 9, p. 66, pl. 10, figs. 3a-c, 1932. [For further references, see Cushman and Ozawa, U. S. Nat. Mus. Proc., vol. 77, art. 6, p. 60,1930 .]

Test globular to subglobular, transverse section almost circular; chambers few, inflated, rounded, arranged in a nearly triserial series; sutures not depressed, generally clear; wall smooth, translucent, often with fistulose tubes, especially at the apertural end; aperture radiate.

We have no further specimens of this species to add to the records already published from the Miocene. It has previously been recorded from the Choctawhatchee formation of Florida in Walton, Leon, and Calhoun Counties, and from the Shoal River, Oak Grove, and Chipola formations.

\section{Globulina inaequalis Reuss}

Plate 6, Figures 7, 8

Globulina inaequalis Reuss, K. Akad. Wiss. Wien Denkschr., vol. 1 , p. 377 , pl. 48 , fig. $9,1850$.

Cushman, Florida Geol. Survey Bull. 4, p. 35, pl. 5, fig. 22, 1930.

Cushman and Ponton, Florida Geol. Survey Bull. 9, p. 66, pl. 10, figs. 1a-c, 1932. [For further references to this species, see Cushman and Ozawa, U. S. Nat. Mus. Proc., vol. 77 , art. 6 , p. $73,1930$.

Test ovate, more or less compressed, broadly rounded at the base, tapering toward the apex; chambers few, inflated, much overlapping, arranged in a nearly triserial series; sutures very slightly if at all depressed, distinct; wall smooth, translucent; aperture radiate. Length $0.40-0.60 \mathrm{~mm}$; breadth $0.25-0.40 \mathrm{~mm}$.

This is a very widely distributed species. It has previously been recorded from the Choctawhatchee formation of Florida from Leon, Walton, and Washington Counties. Our material has added records from the Yorktown formation of Virginia, the Yorktown formation and the Duplin marl of North Carolina, and the Calvert and Choptank formations of Maryland.

\section{Globulina rotundata (Bornemann)}

\section{Plate 6, Figure 9}

Guttulina rotundata Bornemann, Deutsche geol. Gesell. Zeitschr., vol. 7 , p. 346 , pl. 18 , fig. 3,1855 .

Globulina rotundata Cushman, Florida Geol. Survey Bull. 4, p. 35 , pl. 5, fig. 16,1930 .

Cushman and Ponton, Florida Geol. Survey Bull. 9, p. 67, 1932. [For further references to this species, see Cushman and Ozawa, U. S. Nat. Mus. Proc., vol. 77, art. 6, p. $86,1930$.

Test ellipsoidal or ovoid to cylindrical, rounded at the base, slightly produced at the apertural end; chambers rounded, almost as long as broad, arranged in a nearly triserial series, each succeeding chamber removed much farther from the base, rarely becoming almost uniserial in the last chamber; sutures but little depressed, generally distinct; wall smooth, thick, often with fistulose tubes; aperture radiate.

The species has occurred in the Choctawhatchee formation at several stations in Walton County, Fla., but has not occurred in any more recently studied material from the area to the north. 
Genus PSEUDOPOLYMORPHINA Cushman and Ozawa, 1928

Pseudopolymorphina dumblei (Cushman and Applin)

Plate 6, Figures 10a, b

Polymorphina compressa D’Orbigny var. dumblei Cushman and Applin, Am. Assoc. Petroleum Geologists Bull., vol. 10, p. 173, pl. 9, figs. 4, 5, 1926.

Pseudopolymorphina dumblei Cushman and Ozawa, U. S. Nat. Mus. Proc., vol. 77, art. 6, p. 97, pl. 25, figs. 1a, b, 1930. Cushman, Florida Geol. Survey Bull. 4, p. 35, pl. 6, fig. 5, 1930.

Cushman and Ponton, Florida Geol. Survey Bull. 9, p. 67, 1932.

Test compressed, elongated, obtuse at the base, more or less acute at the apertural end; chambers slightly longer than wide, more or less compressed, much embracing, arranged at first in a nearly triserial series, becoming biserial later; sutures but little depressed, distinct; wall smooth; aperture radiate. Length 0.75 $\mathrm{mm}$; breadth $0.35 \mathrm{~mm}$.

Specimens referred to this species have already been recorded from the Choctawhatchee formation of Florida from Calhoun, Liberty, and Walton Counties, as well as from the Shoal River and Chipola formations. Miocene records added by our studies are from the St. Marys and Calvert formations of Maryland.

\section{Pseudopolymorphina rutila (Cushman)}

Plate 6, Figure 11

Polymorphina regina H. B. Brady, Parker, and Jones var. rutila Cushman, U. S. Geol. Survey Prof. Paper 133, p. 34, pl. 5, figs. 7, 8, 1923.

Pseudopolymorphina rutila Cushman and Ozawa, U. S. Nat. Mus. Proc., vol. 77, art. 6, p. 100, pl. 26, figs. 3a, b, 1930.

Cushman, Florida Geol. Survey Bull. 4, p. 36, pl. 5, fig. 20, 1930.

Cushman and Ponton, Florida Geol. Survey Bull. 9, p. 67, 1932.

Test compressed, elongate, fusiform, with a strong spine at the base; chambers more or less elongated, not much embracing, alternating; sutures more or less depressed, distinct; wall marked with a few strong, longitudinal costae; aperture radiate. Length 1.05 $\mathrm{mm}$; breadth $0.30 \mathrm{~mm}$.

This is a common species in the lower Oligocene of Mississippi, and there are records for it in the Choctawhatchee formation of Calhoun, Leon, and Washington Counties, Fla. No further records were added by our studies of the more extensive Miocene material.

\section{Pseudopolymorphina striata (Bagg)}

Plate 6, Figures 12, 13

Polymorphina compressa var. striata Bagg, Maryland Geol. Survey, Miocene, p. 476, pl. 133, fig. 2, 1904.

Polymorphina regina Bagg, op. cit., p. 378, pl. 133, fig. 7.

Polymorphina compressa Bagg, op. cit., p. 476, pl. 133, fig. 1.

Pseudopolymorphina striata Cushman and Ozawa, U. S. Nat. Mus. Proc., vol. 77, art. 6, p. 92, pl. 23, figs. 5a-c, 1930.
Test compressed, elongated, base rounded; chambers longer than broad, not much embracing, arranged at first in a nearly contraclockwise, quinqueloculine series, later becoming regularly biserial with the chambers alternating; sutures slightly depressed, distinct; wall marked with fine longitudinal costae, typically covering the entire test; aperture radiate. Adult specimen, length $1.30-1.60 \mathrm{~mm}$; breadth $0.42-0.50 \mathrm{~mm}$.

The records for the species are all from Maryland, from the Choptank formation 2 $\frac{1}{2}$ miles below Governor Run, Chesapeake Bay; 1 mile below Governor Run; and Point of Rocks, about $1 \frac{1}{2}$ miles below Flag Pond, Chesapeake Bay, and from the Calvertformation of Chesapeake Beach and Plum Point.

This is a highly ornamented species, somewhat variable in form and size but retaining its general characters rather clearly.

\section{Genus SIGMOMORPHINA Cushman and Ozawa, 1928}

\section{Sigmomorphina williamsoni (Terquem)}

\section{Plate 6, Figure 14}

Polymorphina williamsoni Terquem, Soc. géol. France Mém., sér. 3, vol. 1, p. 37, 1878.

Sigmomorphina williamsoni Cushman and Ozawa, U. S. Nat. Mus. Proc., vol. 77, art. 6, p. 138, pl. 38, figs. 3, 4, 1930.

Cushman, Florida Geol. Survey Bull. 4, p. 36, pl. 6, fig. 4, 1930.

Cushman and Ponton, Florida Geol. Survey Bull. 9, p. 67, 1932.

Polymorphina lactea Walker and Jacob var. oblonga Williamson, Recent Foraminifera of Great Britain, p. 71, pl. 6, figs. 149, 149a, 1858.

Test ovate to oblong, compressed, of nearly equal thickness, sides nearly parallel, rounded at both ends; chambers elongated, embracing, arranged in a contraclockwise, sigmoid series, each succeeding chamber extending down to the base; sutures scarcely depressed but distinct; wall smooth, thin, nearly transparent; aperture long, radiate, furnished with an entosolenian tube. Length $0.45 \mathrm{~mm}$; breadth $0.30 \mathrm{~mm}$.

The only record from the Miocene of the eastern United States is that from the Choctawhatchee formation at S. D. Johnson's place, near Woods, Liberty County, Fla.

\section{Genus SIGMOIDELLA Cushman and Ozawa, 1928}

\section{Sigmoidella cf. S. kagaensis Cushman and Ozawa}

Plate 6, Figures 15a, b

The only specimen of this genus found in our studies of this Miocene material is from the Calvert formation of Maryland. It has many of the characteristics of S. kagaensis, but is far from the other known localities for that species, which are all in the region from Japan to Australia. S. kagaensis is, however, recorded from the Miocene of Australia. 


\section{Family NONIONIDAE \\ Genus NONION Montfort, 1808 \\ Nonion grateloupi (D'Orbigny)}

Plate 7, Figures 1a, b

Nonionina grateloupi D'Orbigny, Annales sci. nat., vol. 7, p. 294, No. 19, 1826; in De la Sagra, Histoire physique, politique et naturelle de l'île de Cuba, Foraminifères, $p$. 46, pl. 6, figs. 5, 7, 1839 .

Fornasini, Accad. sci. Ist. Bologna Mem., 6th ser., vol. 1, p. 12, pl. 3, fig. 5, 1904 .

Cushman, Carnegie Inst. Washington Pub. 291, p. 48, 1919; U. S. Nat. Mus. Proc., vol. 59, p. 61, pl. 14, figs. 9-11, 1921; Carnegie Inst. Washington Pub. 311, p. 55, pl. 9, figs. 7,8 , 1922; Pub. 344 , p. 79 , 1926; U. S. Nat. Mus. Bull. 104, pt. 7, p. 10, pl. 3, figs. 9-11; pl. 4, figs. 1-4, 1929.

Nonionina scapha Cushman (not Fichtel and Moll), U. S. Nat. Mus. Bull. 103, p. 73 , pl. 25, figs. $6 a$, b, 1918; U. S. Geol. Survey Bull. 676, p. 68, pl. 25, fig. 2; pl. 26, figs. 2, 3, 1918.

Nonion grateloupi Cushman, Florida Geol. Survey Bull. 4, p. 36, pl. 6, figs. 1-3, 1930.

Cushman and Ponton, Florida Geol. Survey Bull. 9, p. 68, 1932.

Test typically planispiral and bilaterally symmetrical but often becoming somewhat trochoid, mostly involute, in peripheral view the sides nearly parallel, periphery rounded; chambers numerous, usually 10 to 12 in the last-formed coil in adults, chambers increasing rapidly in length, especially in the few chambers; sutures distinct, slightly depressed; wall smooth, finely perforate; aperture small, at the base of the lastformed chamber, narrow. Length up to $0.60 \mathrm{~mm}$; breadth $0.35 \mathrm{~mm}$; thickness $0.20 \mathrm{~mm}$.

This species is a common one in Recent collections from the West Indian region, from which it was first described. It is known from widely separated regions of the Miocene of the general region, being recorded from Cuba, Santo Domingo, and Panama and from a number of localities in the Choctawhatchee, Shoal River, Oak Grove, and Chipola formations of Florida. Our material shows some questionable specimens from the Choptank and Calvert formations of Maryland and the Yorktown formation of Virginia. It is evidently a species which has had its habitat in warm shallow waters, as all the localities in the Miocene and Recent material are in beds representing such conditions. It is probable that the species described as Nonionina extensa Cushman, ${ }^{8}$ from the Duplin marl of Mayesville, S. C., is a narrow form of this species. Such forms occur in any large series of specimens of this species.

\section{Nonion pizarrense Berry}

Plate 7, Figures 2a, b

Nonion pizarrensis Berry, Jour. Paleontology, vol. 1, p. 269, figs. 1-3 (in text), 1928.

Cushman and Kellett, U. S. Nat. Mus. Proc., vol. 75, art. 25, p. 4, pl. 1, figs. 10a, b; pl. 2, figs. 1a, b, 1929.

Cushman and Ponton, Florida Geol. Survey Bull. 9, p. 69, 1932.

${ }_{8}$ Cushman, J. A., U. S. Geol. Survey Bull. 676, p. 69, pl. 25, fig. 4, 1918.
Nonionina depressula Cushman (not Walker and Jacob), U. S. Nat. Mus. Bull. 103, p. 72, pl. 25, figs. 5a, b, 1918.

Nonionina boueana Cushman (not D'Orbigny), U. S. Geol. Survey Bull. 676, p. 68, pl. 25, fig. 3, 1918.

Test nearly bilaterally symmetrical, slightly longer than broad in side view; periphery broadly rounded, umbilici depressed but not usually open; chambers 12 to 15 in the last-formed coil, elongate, curved, the apertural face convex; sutures distinct, strongly depressed at the inner end, becoming less so toward the periphery, gently curved; wall smooth, polished, very finely perforate, often roughened about the umbilicus; aperture elongate, at the base of the apertural face, of ten slightly more extended on one side than the other. Length $0.60-0.80 \mathrm{~mm}$; breadth $0.45-0.60 \mathrm{~mm}$; thickness $0.22-0.35 \mathrm{~mm}$.

This species was originally described from the west coast of South America, where it is common. It is also known from the Miocene Gatun formation of Panama and is abundant in the Choctawhatchee formation of Walton County, Fla., and occurs in the Shoal River and Chipola. Specimens are abundant in some of our material, particularly from the St. Marys and Calvert formations of Maryland, and rather rare in the Yorktown formation of Virginia.

\section{Nonion glabrellum Cushman \\ Plate 7, Figures $3 a, b$}

Nonion glabrella Cushman, Florida Geol. Survey Bull. 4, p. 38, pl. 6, figs. 6a, b, 1930.

Cushman and Ponton, Florida Geol. Survey Bull. 9, p. 69, 1932.

Test planispiral, bilaterally symmetrical, periphery rounded, tending to become slightly uncoiled in the adult; chambers six or seven in the coil, increasing rather rapidly in size in the adult, the slightly uncoiled chambers much the largest; sutures distinct, later ones somewhat open and limbate, very slightly curved; wall smooth and highly polished, very finely perforate; aperture narrow, at the base of the apertural face. Length of holotype $0.30 \mathrm{~mm}$; breadth $0.20 \mathrm{~mm}$; thickness $0.10 \mathrm{~mm}$.

This species, already described from the Choctawhatchee formation of Florida, occurs also in the Shoal River, Oak Grove, and Chipola of Florida. It has not been found in any of our material from the Miocene to the north of Florida.

\section{Nonion incisum (Cushman) \\ Plate 7, Figures 4a, b}

Nonionina incisa Cushman, Contr. Cushman Lab. Foram. Research, vol. 1 , pt. 4 , p. 90 , pl. 13, figs. 3a-c, 1926; vol. 2 , pt. 3, p. $65,1926$.

Nonion incisa Cushman, Stewart, and Stewart, San Diego Soc. Nat. Hist. Trans., vol. 6, p. 60, 1930.

Cushman and Parker, Contr. Cushman Lab. Foram. Research, vol. 7, p. 7, pl. 1, figs. 26a, b, 1931.

Test longer than broad, periphery acute, composed of numerous chambers, about 15 in the last-formed coil, slightly umbilicate; sutures distinct, deeply incised, 
curved, forming an acute angle with the periphery; wall smooth; in apertural view the apertural face broad, slightly convex, the aperture an elongate narrow arched opening at the base of the apertural face between it and the preceding coil. Length $0.60-0.70$ $\mathrm{mm}$; breadth $0.45-0.50 \mathrm{~mm}$; thickness $0.30-0.35 \mathrm{~mm}$.

This species was not recorded from the Miocene of Florida, but specimens which seem to be typical occurred in our collections from the St. Marys formation of Virginia and the Choptank formation of Maryland. This species was originally described from the Monterey Miocene of California, and there are numerous records of it from that State.

\section{Nonion pompilioides (Fichtel and Moll)}

Plate 7, Figures 5a, b

This form was recorded and figured in 1918 from Centerville, Md., as Nonionina umbilicatula (Montagu) Parker and Jones. ${ }^{9}$ The original specimen has been lost, and no other material referable to this species has been found.

\section{Genus NONIONELLA Cushman, 1926}

\section{Nonionella auris (D'Orbigny)}

Plate 7, Figures $6 a, b$

Valvulina auris D'Orbigny, Voyage dans l'Amérique méridionale, vol. 5, pt. 5, Foraminifères, p. 47, pl. 2, figs. 15-17, 1839. Nonronella auris Cushman and Kellett, U. S. Nat. Mus. Proc., vol. 75 , art. 25 , p. 5 , pl. 1, fig. 9 ; pl. 2, figs. 2 , 3, 1929.

Cushman, Florida Geol. Survey Bull. 4, p. 38, pl. 7, figs. 1a-c, 1930.

Cushman and Ponton, Florida Geol. Survey Bull. 9, p. 69, 1932.

Test asymmetrical, slightly trochoid, the spire not raised, periphery in the adult broadly rounded; chambers 9 to 11 in the adult, low and broad, very distinct, slightly inflated, in the adult with the lastformed chamber having an enlarged portion extending over the umbilicus on the ventral side; sutures distinct, depressed, gently curved; wall smooth, polished, very finely perforate; aperture at the base of the last-formed chamber extending from the periphery ventrally, low and broad. Length $0.40 \div 0.45 \mathrm{~mm}$; breadth $0.30-0.35 \mathrm{~mm}$; thickness $0.18-0.20 \mathrm{~mm}$.

The species has already been recorded from the Miocene of Florida, where it occurs in considerable numbers in the Choctawhatchee formation, as well as at most of the stations in the Shoal River, Oak Grove, and Chipola. As a Recent form it is known from the west coast of South America. Our later collections have specimens apparently of this same species from the Yorktown formation of Virginia and from the St. Marys and Calvert formations of Maryland.

9 U. S. Geol. Survey Bull. 676, p. 69, pl. 26, fig. 6, 1918.

\section{Genus ELPHIDIUM Montfort, 1808}

\section{Elphidium poeyanum (D'Orbigny)}

Plate 7, Figures 7a, b

Polystomella poeyana D'Orbigny, in De la Sagra, Histoire physique, politique et naturelle de l'île de Cuba, Foraminifères, p. 55, pl. 6, figs. 25, 26, 1839.

Cushman, Carnegie Inst. Washington Pub. 311, p. 55, pl. 9, figs. 9, 10, 1922; Pub. 344, p. 79, 1926.

Elphidium poeyanum Cushman, U. S. Nat. Mus. Bull. 104, pt. 7, p. 25, pl. 10, figs. 4, 5, 1929; Florida Geol. Survey Bull. 4, p. 39, pl. 7, figs. 3, 4, 1930.

Cushmań and Ponton, Florida Geol. Survey Bull. 9, p. 69, 1932.

Polystomella striato-punctata Cushman (not Fichtel and Moll), U. S. Nat. Mus. Bull. 104, p. 74, pl. 26, figs. 3, 4, 1918; U. S. Geol. Survey Bull. 676, pp. 19, 69, pl. 8, fig. 4; pl. 26 , fig. 4 (?); pl. 27, fig. 2, 1918; U. S. Geol. Survey Prof. Paper 128, p. 71, pl. 11, fig. 17, 1920.

Test of small size for the genus, strongly compressed, periphery broadly rounded, margin slightly lobulate, sides nearly parallel in peripheral view, umbilical regions slightly depressed; chambers averaging 10 to 12 in the last-formed coil but variable, very slightly inflated, very distinct; sutures slightly depressed, marked by the very short, broad retral processes, averaging about 15 in Recent specimens and less in the fossil ones; wall thin, translucent, smooth, conspicuously but finely perforate; aperture composed of a series of small rounded openings at the base of the apertural face. Diameter up to $0.50 \mathrm{~mm}$; thickness $0.20 \mathrm{~mm}$.

This is a very common species, rather widely distributed in the West Indian region, from which it was originally described. It occurs in the Miocene Choctawhatchee formation of Florida in several counties and is widely distributed in the later collections from the Shoal River, Oak Grove, and Chipola, as well as in those which we have examined from the north, occurring in the Duplin marl of South Carolina and North Carolina, the Yorktown formation of North Carolina and Virginia, and the St. Marys and Choptank formations of Maryland.

\section{Elphidium incertum (Williamson)}

Plate 7, Figure 8

Polystomella umbilicatula var. incerta Williamson, Recent Foraminifera of Great Britain, p. 44, pl. 3, figs. 82, 82a, 1858.

Elphidium incertum Cushman, U. S. Nat. Mus. Bull. 104, pt. 7, p. 18, pl. 7, figs. 4-9, 1929; Florida Geol. Survey Bull. 4, p. 39, pl. 7 , figs. $2 a, b, 1930$.

Cushman and Ponton, Florida Geol. Survey Bull. 9, p. 70, 1932.

Nonionina depressula Cushman (not Walker and Jacob), U. S. Geol. Survey Bull. 676, p. 67, pl. 26, fig. 1, 1918.

Test of small size for the genus, compressed, periphery broadly rounded, margin entire or with the last 
two or three chambers lobulated, umbilical regions slightly depressed, often with a slight knob or irregularly arranged slits at the base of the sutures; chambers few, usually less than 10 in the last-formed coil, slightly inflated, distinct; sutures distinct, mainly marked by the openings, retral processes few, usually not more than 5 to 7 ; wall thick, usually opaque; aperture composed of several small, rounded openings at the base of the apertural face. Diameter $0.50 \mathrm{~mm}$; thickness $0.23 \mathrm{~mm}$.

This is a common species in the cooler waters off the eastern coast of the United States, as well as off the coast of Europe. It has already been recorded from the Choctawhatchee formation of Florida and is the most common species of the genus in the Miocene to the north, occurring in the Duplin marl of both North and South Carolina, the Yorktown and St. Marys formations of Virginia, and the Choptank, Calvert, and St. Marys formations of Maryland. Some of the specimens tend toward the variety clavatum.

\section{Elphidium sagrum (D’Orbigny)}

Plate 7, Figures 9a, b

Polystomella sagra D'Orbigny, in De la Sagra, Histoire physique, politique et naturelle de l'île de Cuba, Foraminifères, p. 55, pl. 6, figs. $19,20,1839$.

Cushman, U. S. Nat. Mus. Bull. 103, p. 75, pl. 26, figs. 5a, b, 1918; Carnegie Inst. Washington Pub. 291, p. 49, 1919; U. S. Geol. Survey Prof. Paper 128, p. 71, pl. 11, figs. 20, 21, 1920.

Polystomella lanieri Cushman (not D'Orbigny), U. S. Geol. Survey Prof. Paper 128, p. 72, pl. 11, fig. 22, 1920.

Elphidium sagrum Cushman, U. S. Nat. Mus. Bull. 104, pt. 7, p. 24, pl. 9, figs. 5, 6, 1929; Florida Geol. Survey Bull. 4, p. 40 , pl. 7, figs. $6 a, b, 1930$.

Cushman and Ponton, Florida Geol. Survey Bull. 9, p. 70, 1932.

Test of small size for the genus, periphery broadly rounded, margin entire, not lobulate, sides convex in peripheral view, the last-formed portion wider than the earlier portions, umbilical regions somewhat depressed; last-formed chambers slightly inflated, 12 to 15 in the last-formed coil; sutures usually not depressed, marked by the retral processes, which are continuous over the earlier portion of the test to form ridges slightly oblique to the periphery; wall fairly thick, perforate; aperture composed of a series of small, rounded openings at the base of the apertural face. Diameter $0.50 \mathrm{~mm}$; thickness $0.30-0.35 \mathrm{~mm}$.

The original specimens of this species came from shore sands of Cuba, where they are described by D'Orbigny as rare. Although it never occurs in great numbers it is widely distributed in the general West Indian region. It is known from the Miocene of Cuba and Santo Domingo and occurs rarely in the Choctawhatchee formation of Walton County, Fla. We have a very few specimens from the two localities in the Duplin marl of North Carolina.

\section{Elphidium advenum (Cushman)}

Plate 7, Figures 10a, b

Polystomella subnodosa H. B. Brady (not Von Muenster), Challenger Rept., Zoology, vol. 9, p. 734, pl. 110, figs. 1a, b, 1884.

Cushman, U. S. Geol. Survey Bull. 676, p. 70, pl. 27, figs. 6a, b, 1918; Prof. Paper 128, p. 71; pl. 11, fig. 18, 1920.

Polystomella advena Cushman, Carnegie Inst. Washington Pub. 311 , p. 56 , pl. 9 , figs. 11,12 , 1922; Pub. 342 , p. 48 , 1924; Pub. 344, p. 80, 1926.

Elphidium advenum Cushman, U. S. Nat. Mus. Bull. 104, pt. 7, p. 25, pl. 10, figs. 1, 2, 1929; Florida Geol. Survey Bull. 4, p. 40 , pl. 7 , figs. $7 \mathrm{a}, \mathrm{b}, 1930$.

Cushman and Ponton, Florida Geol. Survey Bull. 9, p. 70, pl. 11, figs 1a, b, 1932.

Polystomella crispa Cushman (not Linné), U. S. Geol. Survey Bull. 676, p. 69, pl. 27, figs. 1, 4, 5, 1918; Prof. Paper 128, p. 71 , pl. 11, fig. 19,1920 .

Test of medium size for the genus, strongly compressed, periphery acute, with a narrow carina, often somewhat lobulate, sides nearly parallel in peripheral view, umbilical regions depressed, often with a small, central, clear boss; chambers distinct, 10 to 15 in the last-formed coil, slightly inflated, especially the later ones; sutures usually depressed and chamber wall between them raised; wall distinctly perforate; aperture composed of a few pores at the base of the apertural face. Diameter up to $0.50 \mathrm{~mm}$ or more; thickness $0.15 \mathrm{~mm}$.

In the general West Indian region this species is widely distributed and fairly common as a Recent species. In the Miocene it occurs rather abundantly in the Choctawhatchee formation of Florida at numerous localities, but in our more northern Miocene material it is much less abundant, as would naturally be expected, this being a decidedly warm-water species. Specimens; however, occur at several stations in the Duplin marl of South Carolina. A very similar form occurs in the Pliocene of southern Florida.

\section{Family HETEROHELICIDAE \\ Subfamily PLECTOFRONDICULARIINAE \\ Genus PLECTOFRONDICULARIA Liebus, 1903}

Plectofrondicularia floridana Cushman

Plate 7, Figure 11

Plectofrondicularia floridana Cushman, Florida Geol. Survey Bull. 4, p. 41, pl. 8, fig. 1, 1930.

Cushman and Ponton, Florida Geol. Survey Bull. 9, p. 74, pl. 11, fig. 8, 1932.

Test elongate, tapering, greatest width toward the apertural end, strongly compressed, sides keeled, tricarinate, early portion of the flattened sides with a single median costa; chambers numerous, very distinct, increasing in height toward the apertural end; sutures very distinct, slightly depressed, each half somewhat sigmoidally curved, slightly limbate; wall smooth except for the median costa; aperture elliptical, terminal. Length of holotype, $0.80 \mathrm{~mm}$; breadth $0.25 \mathrm{~mm}$; thickness $0.08 \mathrm{~mm}$. 
This is a species known to occur in the Miocene only, in the Choctawhatchee formation of Florida, although it occurs there in considerable numbers. It is, as previously noted, related to $P$. californica Cushman and Stewart, which is very abundant in the Pliocene of California, but the Florida species is distinctive. No additional specimens were found to extend the distribution of this species northward in the Miocene.

\section{Plectofrondicularia mansfieldi Cushman and Ponton}

Plate 7, Figures 12a, b

Plectofrondicularia mansfieldi Cushman and Ponton, Contr. Cushman Lab. Foram. Research, vol. 7, p. 60, pl. 8, figs. 1 a, b, 1931; Florida Geol. Survey Bull. 9, p. 74, pl. 11, figs. 7 a, b, 1932.

Test very much compressed, much elongated, very slightly tapering, the later portion with the sides nearly parallel, sides sharply truncate or slightly concave with distinct keels, giving a narrow rectangular shape in end view; chambers numerous, the earliest ones biserial, soon becoming uniserial and increasing rather rapidly in height toward the apertural end, somewhat inflated; sutures very distinct, slightly depressed, especially in the later portion, usually not distinctly limbate, convexly curved; wall mostly smooth, but the basal end with one or two very short costae, and in the adult the later chambers occasionally with fine costae; aperture not shown. Length up to $1.50 \mathrm{~mm}$; maximum breath $0.25 \mathrm{~mm}$; thickness $0.12 \mathrm{~mm}$.

Holotype (Cushman collection No. 15483) from the Miocene of old Frazier farm, NW. 1/4 SE. 1/4 sec. 18, T. 2 N., R. 19 S., Florida. It also occurs in the Shoal River formation of Florida.

This species is a very distinct one from Plectofrondicularia floridana in the sides, which in this species are distinctly truncate and concave, while in $P$. floridana there is a distinct high median keel in addition to the two keels at each side. The sutures also in this species are much more curved, not limbate, and much compressed, all characters very distinct from those of $P$. floridana. The chambers also are much higher than those of $P$. floridana.

\section{Family BULIMINIDAE}

\section{Subfamily TURRILININAE}

Genus BULIMINELLA Cushman, 1911

Buliminella elegantissima (D'Orbigny)

Plate 7, Figures 13, 14

Bulimina elegantissima D'Orbigny, Voyage dans l'Amérique méridionale, vol. 5 , No. 5 , Foraminifères, p. 51 , pl. 7 , figs. 13, 14, 1839.

Schlumberger, Feuille des jeunes naturalistes, ann. 12, p. 8, pl. 1, fig. 14, 1882.

H. B. Brady, Challenger Rept., Zoology, vol. 9, p. 402, pl. 50, figs. 20-22, 1884.

Sidebottom, Manchester Lit. Philos. Soc. Mem. and Proc., vol. 49 , No. 5, p. 11, pl. 2, fig. $6,1905$.
Buliminella elegantissima Cushman, U. S. Nat. Mus. Bull. 71, pt. 2 , p. 89,1911 ; U. S. Nat. Mus. Proc., vol. 56 , p. 606 , 1919; Contr. Cushman Lab. Foram. Research, vol. 1, p. 40 , pl. 6, figs. 5a, b, 1925.

Cushman and Kellett, U. S. Nat. Mus. Proc., vol. 75, art. 25, p. 6, pl. 3, figs. 1-3, 1929.

Cushman, Florida Geol. Survey Bull. 4, p. 42, pl. 8, figs. 2, 3, 1930.

Cushman, Stewart, and Stewart, San Diego Soc. Nat. Hist. Trans., vol. 6, p. 64, pl. 4, figs. 7a, b, 1930.

Cushman and Ponton, Florida Geol. Survey Bull. 9, p. 75, 1932.

Test elongate, spiral, making about three volutions, initial end pointed, much more so in the microspheric form; chambers numerous, 7 to 10 in the last-formed whorl, narrow, slightly inflated; sutures distinct, slightly curved, very slightly depressed; wall smooth, finely perforate; aperture elongate, narrow, somewhat enlarged toward the middle of the apertural face. Length up to $0.40 \mathrm{~mm}$; diameter $0.12-0.15 \mathrm{~mm}$.

This species is widely distributed in the Recent material, particularly that from both the east and west coasts of South America. It is very abundant in the Miocene Choctawhatchee formation of Florida, where it is also widely distributed. It is also found in the Shoal River and Oak Grove but not in the Chipola. In our more northern material it has proved to be one of the most abundant species, occurring in the Duplin marl of North Carolina and at nearly all the stations in the Yorktown formation in Virginia, but strangely it did not appear in any of the numerous collections from Maryland except at Chesapeake Beach. This would indicate that it had a somewhat southern range in the Miocene, as it does in the present oceans.

There is a possibility from the records that this species may range into the upper Oligocene, but the general range in America is from the Miocene onward to the present seas.

\section{Buliminella curta Cushman}

Plate 7, Figure 15

Buliminella curta Cushman, Contr. Cushman Lab. Foram. Research, vol. 1, pt. 2, p. 33, pl. 5, fig. 13, 1925; Florida Geol. Survey Bull. 4, p. 43, pl. 8, fig. 4, 1930.

R. E. and K. C. Stewart, Am. Assoc. Petroleum Geologists Bull., vol. 14, p. 1448, 1930.

Cushman and Ponton, Florida Geol. Survey Bull. 9, p. 75, 1932.

Test an elongate spiral, tapering or fusiform, initial end rounded, thence rapidly increasing in diameter until well toward the apertural end, periphery slightly lobulate, spiral suture well marked; chambers numerous, 5 or 6 making up a whorl in the adult, distinct, inflated; sutures distinct, slightly depressed; wall smooth, very finely perforate; aperture comma-shaped in a slightly concave depression of the last-formed chamber. Length up to $0.55 \mathrm{~mm}$; diameter $0.20 \mathrm{~mm}$.

This species, originally described from the Monterey Miocene of California, occurs in the Choctawhatchee, 
Shoal River, and Oak Grove formations but not in the Chipola. The only material that we have had in our present collections occurs at a single station in the Duplin marl of North Carolina.

\section{Genus BULIMINA D'Orbigny, 1826}

\section{Bulimina gracilis Cushman}

Plate 7, Figures $16 a, b$

Bulimina gracilis Cushman, Florida Geol. Survey Bull. 4, p. 43, pl. 8, figs. 5a, b, 1930.

Cushman and Ponton, Florida Geol. Survey Bull. 9, p. 76, 1932.

Test elongate, slender, of nearly uniform diameter for most of its length, about $3 \frac{11}{2}$ times as long as wide in the adult; chambers generally triserial, inflated; sutures distinct, depressed; wall smooth, polished; aperture elongate, narrow. Length $0.60 \mathrm{~mm}$; diameter $0.18-0.20 \mathrm{~mm}$.

This unusual form of Bulimina, which tends to become somewhat biserial, was described from the Choctawhatchee formation of Walton County, Fla., where it is very abundant. It is interesting to note that the species occurs rarely in our more northern collections but is rather widely distributed in North Carolina, in the St. Marys formation of Virginia, and in the Choptank and Calvert formations of Maryland.

\section{Bulimina inflata Seguenza}

Plate 8, Figures 1a, b

Bulimina inflata Seguenza, Accad. gioenia sci. nat. Atti, 2d ser., vol. 18, p. 109, pl. 1, fig. 10, 1862.

Cushman, Florida Geol. Survey Bull. 4, p. 43, pl. 8, figs. $6 a, b, 1930$.

Cushman and Ponton, Florida Geol. Survey Bull. 9, p. 77, 1932. [For further references to this species, see Cushman, U. S. Nat. Mus. Bull. 104, pt. 3, p. 93, pl. 21, fig. 1, 1922.]

Test short, broadest usually above the middle; sutures much depressed; chambers overhanging at the basal edge; upper portion of the test smooth, lower portion with distinct costae growing in thickness toward the basal margin and there ending in stout spines; apical end usually with a stout acicular spine; wall thick. Length $0.50 \mathrm{~mm}$; breadth $0.25-0.30 \mathrm{~mm}$.

This is not a common species in the Miocene of the Coastal Plain region from Florida north. There are scattered specimens recorded from the Choctawhatchee formation of Florida, but we have not had any specimens in our material from the States to the north.

It is possible that the specimens from Norfolk, Va., referred to as B. buchiana in United States Geological Survey Bulletin 676 may be a variant of this species.

Genus VIRGULINA D'Orbigny, 1826

Virgulina (Virgulinella) gunteri Cushman

Plate 8, Figure 2

Virgulina floridana Cushman, Contr. Cushman Lab. Foram. Research, vol. 5, p. 54, pl. 9, figs. 7-10, 1929 (not $V$. floridana Cushman, 1920).
Virgulina gunteri Cushman, op. cit., p. 105; Florida Geol. Survey Bull. 4, p. 44, pl. 9, figs. 1, 2, 1930.

Virgulina (Virgulinella) gunteri Cushman and Ponton, Florida Geol. Survey Bull. 9, p. 80, pl. 12, fig. 7, 1932.

Test two or three times as long as broad, early portion triserial, later chambers irregularly biserial, sides in the adult nearly parallel, greatest width typically at or below the middle; later chambers not greatly inflated; sutures distinct, marked by a row of depressions between the processes that extend backward from the margins of the later-formed chamber; wall smooth, finely perforate; aperture elongate, narrow, extending from the inner margin of the chamber well toward the apex. Length up to $0.60 \mathrm{~mm}$; breadth $0.20 \mathrm{~mm}$; thickness $0.18 \mathrm{~mm}$.

This is a very abundant species in some parts of the Choctawhatchee formation of Florida. It is related to $V$. pertusa Reuss, known from the Miocene and Pliocene of western Europe, but the Florida species is much smaller and more slender, with the greatest width typically at or below the middle of the test and the later chambers not greatly inflated. It is closely related to the species next described.

Virgulina (Virgulinella) miocenica Cushman and Ponton

\section{Plate 8, Figures 3-6}

Virgulina miocenica Cushman and Ponton, Contr. Cushman Lab. Foram. Research, vol. 7, 1931, p. 32, pl. 4, figs. 14-16. Virgulina (Virgulinella) miocenica Cushman and Ponton, Florida Geol. Survey Bull. 9, p. 81, pl. 12, fig. 9, 1932.

Test elongate, slender, somewhat compressed, gradually tapering from the subacute initial end to the greatest breadth formed by the last two chambers, somewhat twisted; chambers numerous, distinct, inflated; sutures distinct, depressed, marked by numerous depressions, the sides of which extend backward to the preceding chamber in short distinct processes; wall except for the markings of the sutures smooth, very finely perforate; aperture very elongate, narrow, slightly curved, running from nearly the apex of the last-formed chamber to the inner margin. Length $0.75-0.90 \mathrm{~mm}$; breadth $0.25-0.30 \mathrm{~mm}$; thickness $0.20-0.25 \mathrm{~mm}$.

Holotype (Cushman collection No. 15481) from the Miocene Shoal River formation, Shell Bluff, Walton County, Fla.

The species Virgulina miocenica has occurred at the following localities:

Shell Bluff on Shoal River about 5 miles north of Mossy Head, Walton County, Fla. Type locality of the Shoal River formation.

Whites Creek about 8 miles south of Argyle, Walton County, Fla. Shoal River formation.

Small branch flowing into Alaqua Creek, about a quarter of a mile west of Alaqua (formerly called Pleasant Ridge) about $4 \frac{1}{2}$ miles southwest of De Funiak Springs, Walton County, Fla. Cardium bed, Shoal River formation.

Vaughans Creek, about one-fourth mile below head, 7 miles south of De Funiak Springs, Walton County, Fla. Choctawhatchee (?) formation. 
Yellow River at old mill about 100 yards below highway bridge on Laurel Hill-Oak Grove road, about one-fourth mile south of Oak Grove. Type locality of Oak Grove sand.

Tanners Mill (old Senterfeit Mill), $4 \frac{1}{2}$ miles southwest of Laurel Hill, Walton County, Fla. Oak Grove sand.

It also occurs in the Miocene Choptank, St. Marys, and Calvert formations of Maryland.

This species is abundant in the Shoal River and rare in the Oak Grove. It is very different in shape from $V$. gunteri, having its greatest width toward the apertural end but being much more slender and tapering as well as smaller than $V$. pertusa Reuss, of Europe.

\section{Virgulina punctata D'Orbigny}

Plate 8 , Figures $8 \mathrm{a}, \mathrm{b}$

Virgulina punctata D’Orbigny, in De la Sagra, Histoire physique, politique et naturelle de l'île de Cuba, Foraminifères, p. 139, pl. 1, figs. 35, 36, 1839.

Cushman, Carnegie Inst. Washington Pub. 291, p. 35 , 1919; U. S. Nat. Mus. Proc., vol. 59, p. 52, pl. 11, fig. 15, 1921; Carnegie Inst. Washington Pub. 311, p. 31, pl. 3, fig. 9, 1922; U. S. Nat. Mus. Bull. 104, pt. 3, p. 117, 1922; Florida Geol. Survey Bull. 4, p. 44, pl. 8, figs. $7 \mathrm{a}, \mathrm{b}, 1930$.

Cushman and Ponton, Florida Geol. Survey Bull. 9, p. 79, 1932.

Virgulina squamosa Cushman (not D'Orbigny), U. S. Nat. Mus. Bull. 103, p. 58, pl. 21, fig. 6, 1918.

Test elongate, compressed, fusiform, broadest near the middle, initial end bluntly pointed; chambers numerous, earliest ones triserial, later ones biserial, inflated; sutures distinct, slightly depressed; wall smooth, punctate; aperture elongate. Length 0.60 $\mathrm{mm}$; breadth $0.20 \mathrm{~mm}$; thickness $0.10 \mathrm{~mm}$.

This is not a common species in the Miocene of Florida and was represented in our collections from the Yorktown formation of Virginia at only one station. It is, however, a common species in the general West Indian region at the present time and is known from the Miocene of the gorge of the Yumuri River, Matanzas, Cuba, and from the Miocene Gatun formation of the Canal Zone.

\section{Virgulina fusiformis Cushman \\ Plate 8, Figures 7a, b}

Virgulina fusiformis Cushman, Florida Geol. Survey Bull. 4, p. 45 , pl. 8, figs. 8a, b, 1930 .

Cushman and Ponton, Florida Geol. Survey Bull. 9, p. 79, 1932.

Test small, somewhat compressed, fusiform, greatest breadth at about the middle, ends bluntly pointed; chambers distinct, earliest ones triserial, later ones biserial, inflated; sutures very slightly depressed; wall smooth, very finely perforate; aperture elliptical, very small at the upper end of the test, reaching the inner margin of the chamber. Length $0.30 \mathrm{~mm}$; breadth $0.12 \mathrm{~mm}$; thickness $0.08 \mathrm{~mm}$.

This is a small but rather well characterized species that was described from the Choctawhatchee forma- tion, where it occurs in the upper fossiliferous bed at Alum Bluff, on the Apalachicola River, Liberty County, and also at Harveys Creek, Leon County, Fla. No further specimens of this species were found to the north.

\section{Genus BOLIVINA D'Orbigny, 1839}

\section{Bolivina marginata Cushman}

Plate 8, Figures $9 \mathrm{a}, \mathrm{b}$

Bolivina marginata Cushman, U. S. Geol. Survey Bull. 676, p. 48, pl. 10, fig. 1, 1918; Contr. Cushman Lab. Foram. Research, vol. 1, p. 30, pl. 5, figs. 5a, b, 1925; Florida Geol. Survey Bull. 4, p. 45, pl. 8, figs. 9a, b, 1930.

Cushman and Parker, Contr. Cushman Lab. Foram. Research, vol. 7, p. 9, pl. 2, fig. 1, 1931.

Cushman and Ponton, Florida Geol. Survey Bull. 9, p. 81, 1932.

Test much compressed, of medium size for the genus, periphery acute, keeled throughout or sometimes obsolete at the apertural end; sutures usually distinctly limbate, oblique; chambers numerous, distinct, 7 or 8 chambers making up the last half of the test, earlier ones long and narrow, later ones much higher; wall thin, rather coarsely perforate, surface smooth; aperture elongate, narrow. Length usually less than 1.00 $\mathrm{mm}$; breadth $0.25-0.30 \mathrm{~mm}$; thickness $0.12-0.15$ $\mathrm{mm}$.

This species was originally described from the Choctawhatchee formation of Florida. It is fairly common at various stations in Walton County and at one station in Bay County, as well as in the Shoal River, but is apparently absent from the Oak Grove and Chipola. Northward it has occurred only at one station in the Duplin marl of North Carolina. The species is fairly abundant in parts of the Monterey Miocene of California.

Bolivina marginata Cushman var. multicostata Cushman

Plate 8 , Figures $10 a, b$

Bolivina aenariensis (Costa) var. multicostata Cushman, U. S. Geol. Survey Bull. 676, p. 48, pl. 10, fig. 2, 1918.

Bolivina marginata Cushman var. multicostata Cushman, Florida Geol. Survey Bull. 4, p. 46, pl. 8, figs. 13, 14, 1930.

Cushman and Ponton, Florida Geol. Survey Bull. 9, p. 82, 1932.

Variety differing from the typical form in the ornamentation of the test, which consists of a series of longitudinal costae of varying length.

This variety usually occurs with the typical smooth form at the various stations in Florida from which the original was described. However, in the more northern collections the variety occurs without the typical form at stations in the Duplin marl of North Carolina, in the Yorktown formation of North Carolina and Virginia, and in the Calvert formation of Maryland. 


\section{Bolivina floridana Cushman}

Plate 8, Figures 11a, b

Bolivina floridana Cushman, U. S. Geol. Survey Bull. 676, p. 49, p. 10, fig. 4, 1918.

Nuttall, Geol. Soc. London Quart. Jour., vol. 84, p. 74, 1928.

Cushman, Contr. Cushman Lab. Foram. Research, vol. 5, p. 93, 1929; Florida Geol. Survey Bull. 4, p. 46, p. 9, figs. $15 \mathrm{a}, \mathrm{b}, 1930$.

Cushman and Parker, Contr. Cushman Lab. Foram. Research, vol. 7, p. 9, pl. 2, figs. 2, 1931.

Cushman and Ponton, Florida Geol. Survey Bull. 9, p. 82, 1932.

Bolivina decussata Cushman (not H. B. Brady), Contr. Cushman Lab. Foram. Research, vol. 1, p. 31, pl. 5, figs. 6a, b, 1925; vol. 2 , p. 54, 1926.

Test elongate, slightly compressed, gradually tapering, with the greatest width near the apertural end, periphery broadly rounded; chambers numerous, somewhat inflated; sutures indistinct except near the apertural end; the base of each chamber prolonged into lobular processes across the sutures, the intermediate areas deeply excavated; wall coarsely perforate; aperture elongate. Length up to $0.70 \mathrm{~mm}$; breadth 0.20 $0.25 \mathrm{~mm}$; thickness $0.10-0.12 \mathrm{~mm}$.

This species, which was originally described from the Choctawhatchee formation, is very abundant in that formation as it occurs in Walton County, Fla. It is recorded also from Bay County and from the Shoal River formation of Florida. We have not had it from the material we have studied to the north of Florida, but it is a widely distributed Miocene species of this general region, as there are records for it from the Miocene of Trinidad, Venezuela, and California.

\section{Bolivina plicatella Cushman}

Plate 8, Figures 12a, b

Bolivina plicatella Cushman, Florida Geol. Survey Bull. 4, p. 46, pl. 8, figs. $10 \mathrm{a}, \mathrm{b}, 1930$.

Cole, Florida Geol. Survey Bull. 6, p. 41, 1931.

Cushman and Ponton, Florida Geol. Survey Bull. 9, p. 82, 1932.

Test small, short, and broad, compressed, greatest width near the apertural end, periphery subacute; chambers, except the last two, obscured by the ornamentation, which also obscures the sutures; wall ornamented by two distinct longitudinal ridges, rounded or sharp, connected between with transverse ridges, coinciding partially with the chambers, leaving the whole surface broken into series of irregular depressions, coarsely perforate; aperture elongate. Length $0.25-0.30 \mathrm{~mm}$; breadth $0.12-0.15 \mathrm{~mm}$; thickness $0.06-$ $0.08 \mathrm{~mm}$.

The only previous records for this species are those from the Choctawhatchee formation of Florida, where it occurs in Calhoun, Leon, and Liberty Counties, and from the Pliocene of Florida. Our material has added records from three stations in the Duplin marl of North Carolina, and it has occurred in the Calvert formation of Chesapeake Beach, Md.

\section{Bolivina pulchella D'Orbigny var. primitiva Cushman}

Plate 8, Figures 13 a, b

Bolivina pulchella D'Orbigny var. primitiva Cushman, Florida Geol. Survey Bull. 4, p. 47, pl. 8, figs. 12 a, b, 1930 .

Cole, Florida Geol. Survey Bull. 6, p. 41, pl. 2, fig. 10, 1931.

Cushman and Ponton, Florida Geol. Survey Bull. 9, p. 83, 1932.

Variety differing from the typical form in the few biserial chambers, averaging two to four, and the large number of triserial chambers, which make up half of the test; wall coarsely perforate. Length of figured specimen $0.35 \mathrm{~mm}$; breadth $0.20 \mathrm{~mm}$; thickness $0.10 \mathrm{~mm}$.

This variety occurs rarely in the Choctawhatchee formation of Liberty, Leon, and Washington Counties, Fla. It is closely related to the typical form, which is a characteristic species in shallow water in the present West Indian region. Cole records it from the Pliocene of Florida.

\section{Bolivina paula Cushman and Cahill}

Plate 8, Figures $14 \mathrm{a}, \mathrm{b}$

Bolivina paula Cushman and Cahill, in Cushman and Ponton, Florida Geol. Survey Bull. 9, p. 84 , pl. 12, figs. $6 a$, b, 1932.

Test minute, much compressed, periphery subacute, sides for the most part nearly parallel, initial end tapering; chambers numerous, often 12 or more pairs in the adult test, increasing somewhat in height as added, some of the earliest ones being very low; sutures distinct, very slightly if at all depressed, slightly limbate, rather strongly curved backward; wall smooth, finely perforate; aperture an elongate, somewhat comma-shaped opening in the median line of the apertural face. Length $0.30-0.35 \mathrm{~mm}$; breadth 0.15 $\mathrm{mm}$; thickness $0.06-0.08 \mathrm{~mm}$.

Holotype (No. 371,736, U.S.N.M.) from the Yorktown formation, station $1 / 188$, right bank of the York River 2 miles below Yorktown, Va.

This is a very small, somewhat inconspicuous species, but keeps its characters very closely and is often very abundant in this more northern material. We have this species from numerous stations in the Duplin marl and Yorktown formation of North Carolina, in the Yorktown and St. Marys formations of Virginia, and in the Calvert formation of Chesapeake Beach, where it occurs in considerable numbers. It occurs also in the Miocene of Florida.

\section{Genus LOXOSTOMUM Ehrenberg, 1854}

\section{Loxostomum gunteri Cushman}

Plate 8, Figures 15 a, b

Loxostomum gunteri Cushman, Florida Geol. Survey Bull. 4, p. 47, pl. 8, figs. $11 \mathrm{a}, \mathrm{b}, 1930$.

Cushman and Ponton, Florida Geol. Survey Bull. 9, p. 84, 1932.

Test elongate, tapering, greatest breadth near the apertural end, only slightly compressed, periphery 
rounded; chambers and sutures somewhat obscured by the ornamentation of the surface, consisting of fine longitudinal costae, often somewhat broken; aperture narrow, elliptical, terminal in the adult. Length up to $0.50 \mathrm{~mm}$; breadth $0.20 \mathrm{~mm}$; thickness $0.10-0.12 \mathrm{~mm}$.

This distinctive species was described from the Choctawhatchee formation of Walton County, Fla., where it is fairly common. Somewhat similar specimens occur in the Calvert formation at Chesapeake Beach, Md.

\section{Subfamily REUSSIINAE}

Genus REUSSIA Schwager, $\mathbf{1 8 7 7}$

\section{Reussia spinulosa (Reuss)}

Plate 9, Figures $1 \mathrm{a}, \mathrm{b}$

Verneuilina spinulosa Reuss, Akad. Wiss. Wien Denkschr., vol 1, p. 374, pl. 47 , fig. 12, 1850. [For further references to this species, see Cushman, U. S. Nat. Mus. Bull. 104, pt. 3 , p. 60,1922 .]

Reussia spinulosa Schwager, Com. geol. ital. Boll., vol. 8, p. 26. pl., fig. 66, 1877.

Cushman and Kellett, U. S. Nat. Mus. Proc., vol. 75, art. 25, p. 9, pl. 3, figs. 10 a, b, 1929.

Cushman, Florida Geol. Survey Bull. 4, p. 48, pl. 8, figs 17 a, b, 1930.

Cushman and Ponton, Florida Geol. Survey Bull. 9, p. 84, pl. 12, figs. 14-16, 1932.

Test pyramidal, three-sided, triangular in transverse section, the sides flat or slightly concave, the initial end acutely pointed; initial end and angles of chambers often with sharp spines; walls of medium thickness, hyaline, or in some specimens thickened and rough, perforate, smooth, or granular; apertural end of test bluntly angled, the edges of the chambers thickened; aperture a curved slit at the base of the inner edge of the chamber. Length up to $0.75 \mathrm{~mm}$; diameter $0.40 \mathrm{~mm}$.

This is a very widely distributed species in the Miocene, and although specimens were not common, there are numerous records for it in the Choctawhatchee and Oak Grove formations of Florida. The only specimen which we have that can be considered this species came from the Duplin marl of South Carolina.

\section{Genus CHRYSALIDINELLA Schubert, 1907}

Chrysalidinella pulchella (Cushman)

Plate 9, Figures $2 \mathrm{a}, \mathrm{b}$

Chrysalidina pulchella Cushman, U. S. Nat. Mus. Bull. 103 p. 54, pl. 20, figs. 2 a-c, 1918.

Chrysalidinella pulchella Cushman, Florida Geol. Survey Bull. 4, p. 48 , pl. 8, figs. 16 a, b, 1930 .

Cushman and Ponton, Florida Geol. Survey Bull. 9, p. 85, 1932.

Test elongate, gently tapering, broadest at the apical end, triangular in transverse section, early portion triserial, later uniserial; chambers distinct, not inflated; sutures distinct, slightly raised and limbate, curved; wall smooth but coarsely perforate; aperture formed of numerous rounded openings on the terminal face, each at the end of a small papilla. Length of figured specimen $0.40 \mathrm{~mm}$; diameter $0.25 \mathrm{~mm}$.

There are but few records for this species-the type locality, in the Miocene Gatun formation of the Canal Zone; two in the Choctawhatchee formation of Walton and Liberty Counties, Fla.; and a few in the Shoal River and Oak Grove of Florida. It seems to be absent from the Chipola.

\section{Subfamily UVIGERININAE}

\section{Genus UVIGERINA D'Orbigny, 1826}

\section{Uvigerina cf. U. pigmea D'Orbigny}

There are numerous rather closely costate specimens of the sort usually referred to this species, but not typical, well scattered over the Miocene of the general region from Florida to Maryland.

Most of the records for this species are of forms not like the typical form of D'Orbigny, which in its type locality is a very distinctive species. Later, in 1846, in his Vienna Basin paper D'Orbigny figured a very different form under this name, and the characters have been extended by later authors to include many unrelated forms.

\section{Uvigerina auberiana D'Orbigny}

Plate 9, Figure 3

Uvigerina auberiana D'Orbigny, in De la Sagra, Histoire physique, politique et naturelle de l'île de Cuba, Foraminifères, p. 106, pl. 2, figs. 23, 24, 1839 .

Cushman, U. S. Nat. Mus. Bull. 104, pt. 4, p. 163, pl. 42, figs. 3, 4, 1923; Florida Geol. Survey Bull. 4, p. 49, pl. 9, fig. 7, 1930.

Cushman and Ponton, Florida Geol. Survey Bull. 9, p. 86, 1932.

Test elongate, rapidly tapering from the narrow base to the greatest breadth somewhat above the middle, periphery lobulate; chambers inflated; sutures depressed, distinct; wall ornamented with closely set, fine spinose projections, the last-formed chamber often smoother; apertural end in the adult tapering, with an elongate, cylindrical neck and phialine lip. Length up to $0.75 \mathrm{~mm}$; diameter $0.30-0.40 \mathrm{~mm}$.

This species is rare in the Choctawhatchee formation of Walton County, Fla., and very rare in the Shoal River. We have not added any further records to this. As it is not in the present West Indian region, from which it was originally described, it is evidently a rather rare species wherever found. It may be possible that the specimens referred to $U$. canariensis $^{10}$ may be transferred to this species.

${ }_{10}$ Cushman, J. A., U. S. Geol. Survey Bull. 676, pp. 54-55, pl. 12, fig. 2, 1918. 


\section{Genus SIPHOGENERINA Schlumberger, 1883}

\section{Siphogenerina lamellata Cushman}

Plate 9, Figure 4

Siphogenerina lamellata Cushman, U. S. Geol. Survey Bull. 676, p. 55, pl. 12, fig. 3, 1918; U. S. Nat. Mus. Proc., vol. 67, art. 25 , p. 10, pl. 1, fig. 13, 1926; Florida Geol. Survey Bull. 4, p. 49, pl. 9, fig. 10, 1930.

Cushman and Ponton, Florida Geol. Survey Bull. 9, p. 86, 1932.

Test elongate, tapering gradually from the initial end, broadly rounded at the apertural end; chambers comparatively few, somewhat indistinct, surface ornamentation consisting of several equidistant, longitudinal lamellae extending the length of the test and fusing at the initial end; aperture with a tubular neck and phialine lip. Length up to $1.00 \mathrm{~mm}$; diameter 0.45 $\mathrm{mm}$.

This species was originally described from the Choctawhatchee formation 1 mile south of Red Bay, Walton County, Fla., where it is fairly common in that particular phase of the Miocene. We have had no material from the collections made to the north except from the Calvert formation of Chesapeake Beach, Md.

\section{Siphogenerina spinosa Bagg}

Plate 9, Figures 5, 6

Siphogenerina spinosa Bagg, Maryland Geol. Survey, Miocene p. 480 , pl. 133 , fig. $11,1904$.

Cushman, U. S. Geol. Survey Bull. 676, p. 55, 1918.

This peculiar and interesting species somewhat resembles $S$. raphanus Parker and Jones but differs in several particulars. The surface ridges in our specimen end in a series of projecting points, which at the distal end become definite spines, although these are short and stubby. Again there are arched cross ridges between these costae which, while they may not indicate the internal structure of the chambers, serve to mark their location. The aperture ends in a neatly raised phialine everted lip with central, rounded orifice.

The only record for Bagg's species is that from the Choptank formation at Jones Wharf, Md. A copy of his description is given above.

\section{Siphogenerina advena Cushman}

Plate 9, Figures 7a, b

Siphogenerina advena Cushman, Carnegie Inst. Washington Pub. 311, p. 35, pl. 5, fig. 2, 1922; U. S. Nat. Mus. Bull. 104, pt. 4, p. 173, pl. 42, fig. 15, 1923.

There is a single specimen which is here figured from the Duplin marl of South Carolina and which is referred to this species somewhat questionably. The early portion is irregularly triserial, followed by a biserial stage, before the adult uniserial condition is taken on. The whole test is compressed, and the aperture is terminal and elliptical. The surface is somewhat roughened with longitudinal markings.

Genus ANGULOGERINA Cushman, 1927

Angulogerina occidentalis (Cushman)

Plate 9, Figures $8 \mathrm{a}, \mathrm{b}$

Uvigerina angulosa Cushman (not Williamson), Carnegie Inst. Washington Pub. 311, p. 34, pl. 5, figs. 3, 4, 1922.

Uvigerina occidentalis Cushman, U. S. Nat. Mus. Bull. 104, pt. 4, p. 169, 1923.

Angulogerina occidentalis Cushman, Florida Geol. Survey Bull. 4, p. 50, pl. 9, figs. 8, 9, 1930.

Cushman and Ponton, Florida Geol. Survey Bull. 9, p. 86, 1932.

Test minute, elongate, triangular in transverse section, the periphery somewhat lobulate; chambers distinct, those of the last-formed portion becoming more distinct and remote; sutures distinct and depressed; wall ornamented with longitudinal costae on all but the last-formed chambers in the adult; apertural end drawn out into a short, tubular neck and slight, phialine lip. Length usually less than $0.50 \mathrm{~mm}$; diameter $0.15-0.20 \mathrm{~mm}$.

This species is common in the West Indian region of the present ocean and is also fairly common in the Choctawhatchee formation of northwestern Florida. Our collections to the north show this species to be present in the Duplin marl of North Carolina and at several stations in the Yorktown formation of North Carolina and Virginia and the Calvert formation of Maryland.

\section{Family ELLIPSOIDINIDAE}

Genus ELLIPSOLAGENA A. Silvestri, 1923

Ellipsolagena bidens Cushman

Plate 9, Figures 9a, b

Ellipsolagena bidens Cushman, Florida Geol. Survey Bull. 4, p. 50, pl. 9, figs. 11a, b, 1930.

Cushman and Ponton, Florida Geol. Survey Bull. 9, p. 87, 1932.

Test slightly longer than broad, body of the test somewhat oval, apertural end produced but broadly rounded, basal end typically with two short, rounded projections near together in the median line, test in end view broadly elliptical; wall smooth; aperture an elongate slit, slightly more open on one side than the other. Length up to $0.28 \mathrm{~mm}$; ; breadth $0.18 \mathrm{~mm}$.; thickness $0.15 \mathrm{~mm}$.

This small species occurs rather commonly in some parts of the Choctawhatchee formation of Florida, especially in Bay and Walton Counties, although it occurs rarely in Liberty County. We have not been able to add to these records except that from the Calvert formation of Chesapeake Beach, Md. 


\section{Family ROTALIIDAE}

\section{Subfamily SPIRILLININAE}

Genus SPIRILLINA Ehrenberg, 1841

\section{Spirillina orbicularis Bagg}

Plate 9, Figures 10a, b

Spirillina orbicularis Bagg, Bull. Am. Paleontology, vol. 2, No. 10 , p. 33 (327), pl. 2 (22), figs. 2a-c, 1898.

Cushman, U. S. Geol. Survey Bull. 676, p. 58, pl. 14, fig. 1, 1918; Florida Geol. Survey Bull. 4, p. 51, pl. 9, figs. 12a, b, 1930.

Cushman and Ponton, Florida Geol. Survey Bull. 9, p. 87, 1932.

Test planispirally coiled, the coils increasing in diameter as added, periphery broadly rounded, ventral side with rows of beads more or less following the coils, dorsal side with a row of pits along the sutures; aperture arched, comparatively narrow. Diameter about $0.50 \mathrm{~mm}$.

Bagg's types of this species are from the Miocene Yorktown formation of Yorktown, Va. It is also recorded from the Miocene Duplin marl of Mayesville, S. C., and from the Choctawhatchee formation of Florida. We have added material from the Duplin marl of North Carolina. The species seems to hold its characters very closely over this somewhat extended range.

\section{Genus PATELLINA Williamson, 1858}

\section{Patellina advena Cushman}

Plate 9, Figures 11a, b

We have two specimens from a single station from the Miocene of North Carolina, one of which is figured here and is referred to the common. West Indian species of this genus. The chambers are somewhat more divided than in $P$. corrugata. $P$. advena has been living in this general region since early Oligocene time, so far as the records show, and these two specimens are probably to be referred to it.

\section{Subfamily DISCORBISINAE}

\section{Genus DISCORBIS Lamarck, 1804}

\section{Discorbis floridana Cushman}

Plate 9, Figures 12, 13

Discorbis floridana Cushman, Carnegie Inst. Washington Pub 311 , p. 39, pl. 5 , figs. 11,12 , 1922; U. S. Nat. Mus. Bull. 104, pt. 8, p. 21, pl. 4, figs. 7, 8, 1931.

Cushman and Ponton, Florida Geol. Survey Bull. 9, p. 88, pl. 13, figs. 2a-c, 1932.

Discorbis rosacea Cushman (not D'Orbigny), Florida Geol. Survey Bull. 4, p. 51, pl. 9, figs. 13a-c, 1930.

Discorbis subaraucana Cushman, Florida Geol. Survey Bull. 4, p. 52, pl. 10, figs. 1a-c (not Cushman, 1922), 1930.

Test planoconvex, dorsal side convex, ventral side flattened or slightly concave; chambers numerous, but five forming the last adult whorl, much elongated in the adult; sutures very obliquely curved, in the early stages on the dorsal side slightly limbate; wall smooth, finely perforate; aperture ventral, elongate. Diameter up to $1.10 \mathrm{~mm}$.

This species is rather widely distributed in the Miocene of the eastern Coastal Plain of the United States, being known from the Choctawhatchee formation of Leon, Liberty, and Walton Counties, Fla., the Duplin marl of North and South Carolina, the Yorktown and St. Marys formations of Virginia, and the Calvert formation of Maryland.

There are published records for this species from as far back as the Jurassic, but a study of the figures given leads us to suspect that the range is more probably from Miocene to Recent.

\section{Discorbis orbicularis (Terquem)}

\section{Plate 10, Figures 1a-c}

Rosalina orbicularis Terquem, Animaux sur la plage de Dunkerque, p. 75, pl. 9, figs. $4 \mathrm{a}, \mathrm{b}, 1876$.

Discorbis orbicularis Berthelin, Foraminifères de Borgneuf et Pornichet, p. 39, No. 63, 1878.

Cushman, U. S. Nat. Mus. Bull. 71, pt. 5, p. 16, pl. 11, fig. 1, 1915; U. S. Nat. Mus. Bull. 100, vol. 4, p. 305, 1921; Carnegie Inst. Washington Pub. 311, p. 38, pl. 5, fig. 10,1922 ; U. S. Nat. Mus. Bull. 104 , pt. 8 , p. 27 , pl. 6, figs. 3a-c, 1931.

Cushman and Ponton, Florida Geol. Survey Bull. 9, p. 89, pl. 13, figs. 6a-c, 1932.

Discorbina orbicularis H. B. Brady, Challenger Rept., Zoology, vol. 9 , p. 647 , pl. 88 , figs. $4-8,1884$.

Discorbis mira Cushman, Florida Geol. Survey Bull. 4, p. 52, pl. 10, figs. 2a-c, 1930.

Test trochoid, planoconvex, dorsal side forming a low cone, ventral side flattened and very slightly convex, periphery subacute; chambers distinct, not inflated; sutures on the dorsal side limbate, strongly oblique, curved, ventrally somewhat depressed, nearly radial; wall coarsely perforate, smooth; aperture an elongate, slightly arched slit at the ventral margin. Diameter up to $0.65 \mathrm{~mm}$.

This is one of the most common species of the genus in the present waters of the West Indian region. It is a decidedly warm-water species so far as its present records show and occurs rarely in the Choctawhatchee formation of Leon and Liberty Counties, Fla., and the Calvert formation of Chesapeake Beach, Md.

\section{Discorbis candeiana (D'Orbigny)}

\section{Plate 10, Figures 3a-c}

Rosalina candeiana D'Orbigny, in De la Sagra, Histoire physique, politique et naturelle de l'île de Cuba, Foraminifères, p. 97, pl. 4, figs. 2-4, 1839.

Truncatulina candeiana Cushman, U. S. Nat. Mus. Proc., vol. 59, p. 57, pl. 13, figs. 4, 5, 1921; Carnegie Inst. Washington Pub. 311, p. 47, pl. 6, figs. 7-9, 1922; Pub. 344, p. 78, 1926.

Discorbis candeiana Cushman, U. S. Nat. Mus. Bull. 104, pt. 8, p. 19, pl. 7, figs. 4a-c, 1931.

Cushman and Ponton, Florida Geol. Survey Bull. 9, p. 88, pl. 13, figs. 4a-c, 1932.

Discorbis vilardeboana Cushman (not D'Orbigny), Florida Geol. Survey Bull. 4, p. 52, pl. 10, figs. 3a-c, 1930. 
Test planoconvex, dorsal side rather evenly convex, ventral side flattened or slightly concave, umbilicate, periphery rounded; chambers distinct, inflated, 5 to 7 in the adult whorl, the last chamber occupying nearly one-third of the ventral side; sutures distinct, slightly curved, only slightly depressed; wall distinctly perforate, smooth; aperture a narrow slit on the ventral side of the chamber. Diameter up to $0.50 \mathrm{~mm}$.

Specimens have already been recorded from the Choctawhatchee formation of Florida from Calhoun, Leon, and Liberty Counties. We also have it from the Duplin marl of North and South Carolina and from all the stations in the Yorktown and St. Marys formations of Virginia.

There are Cretaceous records for this species, but the figures given show forms that do not appear to be identical with the later Tertiary and Recent material.

\section{Discorbis consobrina (D'Orbigny)}

Plate 10, Figures 4a-c

Rosalina consobrina D'Orbigny, Voyage dans l'Amérique méridionale, vol. 5, pt. 5, Foraminifères, p. 46, pl. 7, figs. 4-6, 1839.

Discorbis consobrina Cushman and Kellett, U. S. Nat. Mus. Proc., vol. 75, art. 25, p. 10, pl. 4, figs. 1, 2, 1929; pl. 10, figs. 4a-c, 1930. Cushman, Florida Geol. Survey Bull. 4, p. 53.

Cushman and Ponton, Florida Geol. Survey Bull. 9, p. 88, pl. 13, figs. 3a-c, 1932.

Test biconvex, the dorsal side more strongly so, ventral side depressed in the umbilical region, periphery rounded; chambers 5 to 7 in the last-formed whorl, distinct, regularly increasing in size as added, slightly inflated, on the ventral side ending in distinct angles at the umbilica! end; sutures distinct, on the dorsal side oblique, very slightly curved, very little if at all depressed, on the ventral side slightly curved, nearly radial, depressed; wall smooth, distinctly perforate; aperture below the distinct lip on the ventral side of the chamber and extending into the umbilical region. Diameter $0.30 \mathrm{~mm}$; height, $0.22 \mathrm{~mm}$.

Our studies of the Miocene north of Florida have not added any records to those of the previous report from Florida except that from the Calvert formation of Chesapeake Beach, Md. Those records included its occurrence in typical form in the Choctawhatchee formation in Calhoun, Leon, and Liberty Counties, Fla.

\section{Discorbis valvulata (D'Orbigny)}

Plate 10, Figures 2, 5

Rosalina valvulata D'Orbigny, Annales sci. nat., vol. 7, p. 271, No. 4, 1826; in Barker-Webb and Berthelot, Histoire naturelle des îles Canaries, vol. 2, pt. 2, Foraminifères, p. 136, pl. 2, figs. 19-21, 1839; in De la Sagra, Histoire physique, politique et naturelle de l'île de Cuba. Foraminifères, p. 96, pl. 3, figs. 21-23, 1839.
Discorbis valvulata Cushman, U. S. Nat. Mus. Proc., vol. 59, pl. 14, figs. 4, 5, 1921; Carnegie Inst. Wäshington Pub. 344, p. 78, 1926; Florida Geol. Survey Bull. 4, p. 53, pl. 10 , figs $5 \mathrm{a}-\mathrm{c}, 1930$.

Cushman and Ponton, Florida Geol. Survey Bull. 9, p. 90, 1932.

Test trochoid, planoconvex, very slightly convex dorsally, on the ventral side flattened or slightly concave, periphery rounded and thickened into a blunt keel; chambers distinct, few, about five making up the adult whorl; sutures curved strongly on the dorsal side, limbate but not depressed, ventrally sinuous, not limbate; wall coarsely perforate, smooth; aperture low, at the base of the last-formed chamber. Length about $0.50 \mathrm{~mm}$; breadth $0.45 \mathrm{~mm}$; thickness $0.12-0.15 \mathrm{~mm}$.

This is a rare species in the present West Indian waters. Rare specimens are recorded from various parts of the Miocene section of Florida. We have specimens from single stations in the Yorktown formation of North Carolina, from the St. Marys formation of Virginia, and from the Calvert formation of Maryland.

\section{Discorbis turrita Cushman}

Plate 10, Figures $6 a-c$

Discorbis turrita Cushman, U. S. Geol. Survey Bull. 676, p. 59, pl. 14, fig. 2, 1918.

A reference to the type slide of this species shows that the specimen is missing. No further specimens of it are available from the collections we have studied from the Yorktown formation of Virginia, from which the types came.

\section{Genus VALVULINERIA Cushman, 1926 \\ Valvulineria floridana Cushman \\ Plate 10, Figures 7a-c}

Valvulineria floridana Cushman, Florida Geol. Survey Bull. 4, p. 54, pl. 10, figs. 6a-c, 1930.

Cushman and Ponton, Florida Geol. Survey Bull. 9, p. 91, 1932.

Test biconvex, somewhat involute on the dorsal side, almost completely so on the ventral side, periphery rounded, earlier portion somewhat angled; chambers inflated, especially on the ventral side, very distinct; sutures distinct, nearly radial, only slightly curved, not limbate; wall smooth, polished; aperture below the distinct, platelike extension of the umbilical end of the chamber. Length $0.45 \mathrm{~mm}$; breadth 0.35 $\mathrm{mm}$; thickness $0.15 \mathrm{~mm}$.

This species, originally described from the Choctawhatchee formation of Florida, occurs at the type locality Econfina, Bay County, and also at various localities in Walton County. It also occurs in the Shoal River and Chipola but not in the Oak Grove. It is interesting to note that in our studies of this supplementary material we have the species from the Yorktown and St. Marys formations of Virginia and 
the Choptank, Calvert, and St. Marys formations of Maryland. This seems to be a well-characterized species and evidently is widely distributed in the Miocene.

\section{Subfamily ROTALIINAE}

Genus EPONIDES Montfort, 1808

\section{Eponides mansfieldi Cushman}

Plate 10, Figures 8a-c

Eponides mansfieldi Cushman, Florida Geol. Survey Bull. 4, p. 54, pl. 11, figs. 1a-c, 1930.

Cushman and Parker, Contr. Cushman Lab. Foram. Research, vol. 7, p. 12, pl. 2, figs. 10a-c, 1931.

Cushman and Ponton, Florida Geol. Survey Bull. 9, p. 92, 1932.

Rotalia beccarii Cushman (not Linné).

Pulvinulina repanda Cushman (not Fichtel and Moll).

Test trochoid, biconvex, close-coiled throughout, all chambers visible from the dorsal side, last whorl completely involute ventrally, periphery acute, bluntly keeled; chambers distinct, slightly inflated on the ventral side, about nine in the adult whorl; sutures distinct, on the dorsal side limbate and usually raised, confluent with the keel and spiral suture, oblique, ventrally depressed, nearly radial; wall on the ventral side strongly papillate, especially in the middle umbonate area and along the sutures, in some specimens with papillae entirely covering the ventral side; aperture ventral, between the periphery and ventral umbo at the base of the chamber. Diameter up to $0.75 \mathrm{~mm}$; thickness $0.25 \mathrm{~mm}$.

This species, recently described from the Choctawhatchee formation of Florida, where it is one of the most abundant and characteristic species of that formation, has proved to be widely distributed in the Miocene. It occurs in the Shoal River but not in the Oak Grove and Chipola formations of Florida. It has already been recorded from California in the Miocene of San Joaquin Valley. In our material it has occurred at nearly all the stations studied, including the Duplin marl of North and South Carolina, the Yorktown and St. Marys formations of Virginia, and the Choptank and St. Marys formations of Maryland. This species is subject to some variation, especially in the amount of roughness on the ventral side of the test, but the general characters remain very definite.

\section{Eponides lateralis (Terquem)}

\section{Plate 11, Figures 1a-c}

Rosalina lateralis Terquem, Soc. géol. France Mém., 1st ser., vol. 4, p. 25, pl. 2 (7), figs. $11 \mathrm{a}-\mathrm{c}, 1878$.

Pulvinulina lateralis H. B. Brady, Challenger Rept., Zoology, vol. 9 , p. 689 , pl. 106. figs. $2,3,1884$

Cushman, Boston Soc. Nat. Hist. Proc., vol. 34 , p. 30 , pl. 5, figs. 11, 12, 1908.

Sidebottom, Manchester Lit. Philos. Soc. Mem. and Proc., vol. 53, No. 21, p. 5, pl. 2, fig. 6; pl. 3, figs. 1, 2, 1909.

Heron-Allen and Earland, Zool. Soc. London Trans., vol. 20, p. 714, pl. 53, figs. 6-11, 1914.

Cushman, U. S. Nat. Mus. Bull. 100, vol. 4, p. 336, pl. 69, figs. $2 \mathrm{a}-\mathrm{c}, 1921$.

$136785^{\circ}-33-3$
Eponides lateralis Cushman, Florida Geol. Survey Bull. 4, p. 55, pl. 10, figs. 7a-c, 1930 .

Cushman and Ponton, Florida Geol. Survey Bull. 9, p. 92, pl. 13, figs. 8a-c, 1932.

Test usually somewhat ovate, biconvex, periphery subacute and keeled; chambers distinct, later ones rapidly enlarging and flaring, inflated somewhat on the ventral side; sutures limbate dorsally, oblique, raised, ventrally depressed, nearly radial; wall smooth except for the raised sutures and on the ventral side the lastformed chamber with numerous large perforations; aperture at the base of the ventral edge of the chamber, low. Length up to $1.50 \mathrm{~mm}$.

This species, already recorded from the Choctawhatchee formation of Florida from Liberty and Washington Counties, has occurred in our material from the Yorktown and St. Marys formations of Virginia, but not in the material from the other States.

Genus ROTALIA Lamarck, 1804

Rotalia beccarii (Linné) var. parkinsoniana (D'Orbigny)

Plate 11, Figures 3a-c

Rosalina parkinsoniana D'Orbigny, in De la Sagra, Histoire physique, politique et naturelle de l'île de Cuba, Foraminifères, p. 99, pl. 4, figs. 25-27, 1839.

Rotalia beccarii (Linné) var. parkinsoniana Cushman, Florida Geol. Survey Bull. 4, p. 56, pl. 11, figs. 3a-c, 1930.

Cushman and Cole, Contr. Cushman Lab. Foram. Research, vol. 6, p. 100, pl. 13, figs. 14a-c, 1930.

Cushman and Ponton, Florida Geol. Survey Bull. 9, p. 93, 1932.

Variety differing from the typical in the number of chambers (which, in the variety, rarely are more than 10 in full-grown specimens in the adult whorl), the shorter, broader chambers on the ventral side, the almost entire lack of beading at the sides of the chambers, and the lack of thickening of the sutures on the dorsal side. Diameter not exceeding $0.50 \mathrm{~mm}$.

D'Orbigny originally described this species from the shore sands of the West Indies. Its occurrence in the Choctawhatchee formation of Florida is peculiar, for it is present in the material from Calhoun, Leon, and Liberty Counties but is lacking in the collections from Walton and Bay Counties. The specimens from these last-named counties represent material from somewhat deeper water, and it is probably due to the fact that this variety lives in shallow water that its absence from these counties has been noted. It occurs in material probably deposited in shallower water in the Shoal River, Oak Grove, and Chipola formations of Florida. Our specimens, which are numerous, are all from the Duplin marl of North and South Carolina and the Yorktown formation of North Carolina, no specimens having occurred in the Virginia and Maryland material. This is probably due to the fact that the variety in its typical form is characteristic of warm waters. It has been recorded from the Pleistocene of Maryland, but in a phase of that formation, which varies greatly in its temperature relations, these specimens probably coming from a warm zone. 
Rotalia bassleri Cushman and Cahill, n. sp.

Plate 11, Figures 2a-c

Test trochoid, planoconvex, dorsal side distinctly convex, ventral side flat or very slightly convex with a distinct large plug in the umbilicate region, periphery acute, very slightly keeled; chambers distinct, usually about seven in the adult whorl, of nearly uniform shape, increasing slightly in size as added, inflated on the ventral side slightly, with a slightly irregular lobe, but on the dorsal side flush with the surface; sutures distinct, slightly limbate on the dorsal side, on the ventral side curved, the inner end often with a slight lobe; wall smooth, finely perforate; aperture a low elongate opening, at the base of the last-formed chamber on the ventral side. Diameter $0.40 \mathrm{~mm}$; height $0.15 \mathrm{~mm}$.

Holotype (No. 372854, U.S.N.M.) from the Calvert formation, Chesapeake Beach, Md.

This species is abundant at Chesapeake Beach, where it occurs almost throughout the section in the material collected by Dr. R. S. Bassler, of the United States National Museum, for whom the species is named. It is a rather small but very distinct species and holds its characters very definitely.

\section{Subfamily BAGGININAE}

Genus CANCRIS Montfort, 1808

Cancris sagra (D'Orbigny)

Plate 11, Figures 4,5

Rotalina sagra D'Orbigny, in De la Sagra, Histoire physique, politique et naturelle de l'île de Cuba, Foraminifères, p. 77 , pl. 5, figs. 13-15, 1839.

Pulvinulina sagra Cushman, U. S. Geol. Survey Bull. 676, p. 65, pl. 22, fig. 3 ; pl. 23, fig. 1, 1918.

Cancris sagra Cushman, Florida Geol. Survey Bull. 4, p. 56, pl. 11, figs. 4a-c, 1930 .

Cushman and Ponton, Florida Geol. Survey Bull. 9, p. 94, pl. 14, figs. $13 \mathrm{a}-\mathrm{c}, 1932$.

Test longer than broad, biconvex, the ventral side more strongly convex than the dorsal, periphery acute; chambers few, 6 to 7 in the adult whorl, increasing rapidly in size as added; sutures slightly depressed on the dorsal side, strongly on the ventral, gently curved; wall smooth; an elliptical area of clearer, thinner wall near the aperture, which is below a slight lip on the ventral side. Length up to $0.75 \mathrm{~mm}$; breadth $0.55-0.70 \mathrm{~mm}$; thickness $0.20-0.30 \mathrm{~mm}$.

This species was originally described by D'Orbigny from shore sands in the West Indies, where it is fairly common. It is best developed in water of some depth and therefore is very abundant and well developed in Walton County, Fla., in the Choctawhatchee formation, and somewhat less so in Bay, Calhoun, and Liberty Counties. The species also occurs in the Shoal River formation but is absent from the Oak Grove and Chipola of Florida. It is found in our later material from the Miocene of North Carolina and from the Yorktown formation of Virginia, where it occurred at several stations. It is a variable species in its general form, owing to the relative difference in the amount of expansion of some of the later chambers.

\section{Family AMPHISTEGINIDAE}

Genus AMPHISTEGINA D'Orbigny, 1826

Amphistegina lessonii D'Orbigny

Plate 11, Figures 6a-c

Amphistegina lessonii D'Orbigny, Annales sci. nat., vol. 7, p. 304, No. 3, pl. 17, figs. 1-4, 1826; Modèles, No. 98 .

Cushman, Florida Geol. Survey Bull. 4, p. 57, pl. 11, figs. 5a-c, 1930.

Cushman and Jarvis, Jour. Paleontology, vol. 4, p. 365 , 1930.

Cushman and Ponton, Florida Geol. Survey Bull. 9, p. 95, pl. 14, figs. 5a-c, 1932. [For further references to this species, see Cushman, U. S. Nat. Mus. Bull. 71, pt. 4, p. $35,1914$.

Test lenticular or more convex on one side than the other, periphery subacute; chambers numerous, fairly distinct, on the dorsal side simple, with a decided angle forward, on the ventral side with supplementary lobes on the inner end; sutures distinct, limbate, not depressed; wall smooth except near the aperture on the ventral side, where it is often papillate; aperture small, ventral.

This species, which is characteristic of warm shallow water of the Tropies, is abundant in the Choctawhatchee formation of Washington County and less so in Leon County, Fla. These two portions of the Miocene represent warm, shallow water conditions, which are favorable for this species. It is present in our material also from the Duplin marl of North and South Carolina, but was not found farther north. It is abundant in the Miocene Bowden marl of Jamaica and occurs in the Oak Grove sand and Chipola formation of Florida. There are records also for the species in the Miocene of Santo Domingo and Trinidad and in the Oligocene of the Canal Zone.

\section{Family CASSIDULINIDAE \\ Subfamily CERATOBULIMININAE \\ Genus PULVINULINELLA Cushman, 1926 \\ Pulvinulinella pontoni Cushman \\ Plate 12, Figures 1a-c}

Pulvinulinella pontoni Cushman, Florida Geol. Survey Bull. 4, p. 57, pl. 11, figs. 2a-c, 1930.

Cushman and Ponton, Florida Geol. Survey Bull. 9, p. 97, 1932.

Test small, trochoid, biconvex, periphery rounded, very slightly if at all lobulate; chambers distinct, usually 8 or 9 in the last-formed whorl, not inflated; sutures distinct, on the dorsal side oblique, slightly limbate, ventrally radial; wall smooth; apertural face obliquely truncate, aperture narrow, parallel to the periphery of the test. Diameter $0.20 \mathrm{~mm}$; thickness $0.08 \mathrm{~mm}$. 
This small but distinctive species, recently described from the Choctawhatchee formation of Florida, has been found also in the Miocene of North Carolina. It also occurs in the Shoal River formation of Florida but is lacking in the Oak Grove and Chipola. Up to the present time these records represent the entire known distribution of the species, but on account of its small size it is easily overlooked, and it may later be found to have a much wider distribution in the American Miocene.

\section{Subfamily CASSIDULININAE \\ Genus CASSIDULINA D'Orbigny, 1826 \\ Cassidulina crassa D'Orbigny \\ Plate 12, Figures 2a-c}

Cassidulina crassa D'Orbigny, Voyage dans l'Amérique méridionale, Foraminifères, p. 56, pl. 7, figs. 18-20, 1839.

Cushman, Contr. Cushman Lab. Foram. Research, vol. 5, p. 100, pl. 14, figs. 10a, b, 1929; Florida Geol. Survey Bull. 4, p. 58, pl. 11, figs. 6a, b, 1930.

Cushman and Ponton, Florida Geol. Survey Bull. 9, p. 97, 1932. [For further references to this species, see Cushman, U. S. Nat. Mus. Bull. 104, pt. 3, p. 124, 1922.]

Test subcircular to oval in outline, biconvex, periphery broadly rounded; chambers comparatively few, short and inflated; sutures distinct, somewhat depressed; wall smooth; aperture elongate, with a flattened tooth partly filling the aperture. Diameter $0.25 \mathrm{~mm}$; thickness $0.18 \mathrm{~mm}$.

This species has already been recorded from the Choctawhatchee formation of Florida, from Calhoun, Liberty, and Walton Counties. Our material has given specimens from the Duplin marl and Yorktown formation of North Carolina, the Yorktown formation of Virginia, and the Calvert formation of Maryland. It is also recorded from the Miocene of Venezuela and is undoubtedly widely distributed in the late Tertiary of America and elsewhere.

\section{Cassidulina laevigata D'Orbigny var. carinata Cushman}

Plate 12, Figures 3a-c

Cassidulina laevigata D'Orbigny var. carinata Cushman, U. S. Nat. Mus. Bull. 104, pt. 3, p. 124, pl. 25, figs. 6, 7, 1922; Florida Geol. Survey Bull. 4, p. 58, pl. 11, figs. 7a, b, 1930.

Cushman and Parker, Contr. Cushman Lab. Foram. Research, vol. 7, p. 14, pl. 2, figs. 14a, b, 1931.

Cushman and Ponton, Florida Geol. Survey Bull. 9, p. 97, 1932.

Variety differing from the typical form in the thinner, more compressed test, with a very distinct, thin carina forming the periphery of the test.

This variety is still living off the coast of Florida and is already known from the Miocene Choctawhatchee of Calhoun, Liberty, and Walton Counties, Fla., and from the Shoal River formation but is lacking in the Oak Grove and Chipola of Florida. It has recently been recorded from the Miocene of California. Our material has shown it to be present in the Yorktown formation of North Carolina and Virginia.

\section{Genus CASSIDULINOIDES Cushman, 1927}

\section{Cassidulinoides bradyi (Norman)}

Plate 12, Figures $4 \mathrm{a}, \mathrm{b}$

Cassidulina bradyi (Norman MS.) J. Wright, Belfast Nat. Field Club Proc., 1880, Appendix, p. 152. [For further references to this species, see Cushman, U. S. Nat. Mus. Bull. 104, pt. 3, p. 128, 1922.]

Cassidulinoides bradyi Cushman, Florida Geol. Survey Bull. 4, p. 58 , pl. 11 , figs. $8 \mathrm{a}, \mathrm{b}, 1930$.

Cushman and Ponton, Florida Geol. Survey Bull. 9, p. 98, 1932.

Test elongate, somewhat compressed, the early portion spirally coiled, later chambers forming an uncoiled, biserial series, lateral faces convex, peripheral border thin, usually somewhat rounded; chambers fairly distinct, but the sutures not depressed; wall smooth and polished; aperture somewhat longer than broad. Length less than $0.50 \mathrm{~mm}$.

The only Miocene records for this species are from the Choctawhatchee and Shoal River formations of Florida. It does not occur in the Oak Grove or Chipola formation, as it is a species of deeper waters than those in which they were deposited.

\section{Family CHILOSTOMELLIDAE \\ Subfamily CHILOSTOMELLINAE \\ Genus CHILOSTOMELLA Reuss, 1850 \\ Chilostomella oolina Schwager}

Chilostomella oolina Schwager, Com. geol. ital. Boll., vol. 9 , p. 527, pl. 1, fig. 16, 1878.

Cushman, Contr. Cushman Lab. Foram. Research, vol. 1, pt. 4, p. 74, pl. 11, figs. 3-10, 1926; Scripps Inst. Oceanography Bull., Tech. ser., vol. 1, p. 169, 1927; Florida Geol. Survey Bull. 4, p. 59, 1930.

Cushman and Moyer, Contr. Cushman Lab. Foram. Research, vol. 6, p. 61 , pl. 8, fig. $15,1930$.

Cushman and Ponton, Florida Geol. Survey Bull. 9, p. 98, 1932.

Test elongate, about three times as long as wide, both ends broadly rounded, sides nearly parallel for most of their length; wall thin, distinctly punctate; aperture very narrow, curved.

The only Miocene record for the east coast of the United States is that from the Choctawhatchee formation of Florida, where the single broken specimen is recorded from Econfina, Bay County. It occurs in the Pliocene of California and is living off that coast. It is a widely distributed species in the present oceans.

\section{Family GLOBIGERINIDAE \\ Subfamily GLOBIGERININAE \\ Genus GLOBIGERINA D'Orbigny, 1826}

There are numerous specimens which belong to this and allied genera of this family. Owing to the present unsatisfactory state of the limits for these species in this genus it has not seemed best to include the members of this family until more work can be done upon them. 
Family GLOBOROTALIIDAE

Genus GLOBOROTALIA Cushman, 1927

Globorotalia menardii (D'Orbigny)

Plate 12, Figures 5a-c

Rotalia menardii D'Orbigny, Annales sci. nat., vol. 7, p. 273 ; Modèles, No. 10, 1826.

Pulvinulina menardii Owen, Linnean Soc. Jour., Zoology. vol. 9 , p. 148, pl. 5, fig. 6,1867 . [For further references to this species, see Cushman, U. S. Nat. Mus. Bull. 71, pt. 5 , p. 54, 1915.]

Globorotalia menardii Cushman, Scripps Inst. Oceanography Bull., Tech. ser., vol. 1, p. 175, 1927; Florida Geol. Survey Bull. 4, p. 60, pl. 12, figs. 1a-c, 1930.

Cole and Ponton, Florida Geol. Survey Bull. 5, p. 45, pl. 11, figs. 4, 5, 1930 .

Cushman and Ponton, Florida Geol. Survey Bull. 9, p. 99, 1932.

Test typically planoconvex, dorsal side slightly convex, ventral side less so or often somewhat concave, umbilicate; peripheral margin thin, slightly lobulated, carinate; chambers 5 or 6 in the adult whorl, slightly inflated ventrally; sutures limbate above, curved below, depressed, radial; wall smooth except granular about the aperture, which is ventral. Diameter of fossil specimens usually less than $0.50 \mathrm{~mm}$.

We have been able to make no additions from our Miocene material. It was previously recorded from the Miocene of Lancaster County, Va., ${ }^{11}$ but a further examination of that material shows that it probably does not belong to this species. The other Miocene localities are in the Choctawhatchee formation of Bay, Calhoun, and Liberty Counties, Fla., and in the Shoal River formation, but it is absent from the Oak Grove and Chipola. Cole and Ponton have recently recorded the species from the lower Oligocene Marianna limestone of Florida.

The single Cretaceous record for this species is without a figure and may easily represent $G$. membranacea, a Cretaceous species easily mistaken for the Tertiary and Recent one.

\section{Family ANOMALINIDAE}

\section{Subfamily ANOMALININAE}

Genus PLANULINA D'Orbigny, 1826

Planulina depressa (D'Orbigny)

Plate 12, Figures 6a-c

Truncatulina depressa D'Orbigny, Voyage dans l'Amérique méridionale, vol. 5 , pt. 5 , Foraminifères, p. 39 , pl. 6 , figs. 4-6, 1839 .

Planulina depressa Cushman, Florida Geol. Survey Bull. 4, p. 60 , pl. 12, figs. $2 a-c, 1930$.

Cushman and Ponton, Florida Geol. Survey Bull. 9, p. 100, 1932.

Test much compressed, not completely involute in the adult, earlier chambers showing on both sides of the test, periphery subacute; chambers numerous, later ones often somewhat irregular, 8 to 10 chambers in the final whorl; sutures distinct, somewhat limbate

11 Cushman, J. A., U. S. Geol. Survey Bull. 676, p. 65, pl. 22, fig. 1, 1918. on the dorsal side, confluent with the keeled edge, on the ventral side depressed; wall very coarsely perforate; aperture at the peripheral margin. Diameter $0.60-0.75 \mathrm{~mm}$; thickness $0.10-0.15 \mathrm{~mm}$.

This species, originally described by D'Orbigny from the coast of South America, seems to be widely distributed and common in the Miocene of the southeastern United States. Specimens have already been recorded from the Choctawhatchee formation of Bay, Calhoun, Liberty, Walton, and Washington Counties, Fla. In addition we have material from the Duplin marl and Yorktown formation of North Carolina, the Yorktown formation of Virginia, and the Choptank formation of Maryland, thus giving this species a rather wide distribution in this area.

\section{Subfamily CIBICIDINAE \\ Genus CIBICIDES Montfort, 1808 \\ Cibicides floridanus (Cushman) \\ Plate 13, Figures 1a-c}

Truncatulina floridana Cushman, U. S. Geol. Survey Bull. 676, p. 62 , pl. 19, fig. 2, 1918.

Truncatulina lobatula (Walker and Jacob) var. ornata Cushman, op. eit., p. 61, pl. 18, figs. 1, 2.

Cibicides floridanus Cushman, Florida Geol. Survey Bull. 4, p. 61, pl. 12, figs. 3a-c, 1930.

Cushman and Parker, Contr. Cushman Lab. Foram. Research, vol. 7, p. 16, pl. 3, figs. 2a-c, 1931.

Cushman and Ponton, Florida Geol. Survey Bull. 9, p. 100, 1932.

Test trochoid, biconvex, dorsal side less convex than the ventral, periphery acute, keeled; chambers numerous, 10 to 12 in the adult whorl; sutures distinct, limbate and raised on the ventral side, fused at the center into an umbonal mass; wall coarsely perforate; aperture extending along the dorsal side of the chamber margin. Diameter up to $0.75 \mathrm{~mm}$.

This species was originally described in 1918 from the Choctawhatchee formation of Florida. It is probably widely distributed, as it occurs in the Miocene Temblor formation of San Joaquin Valley, Calif., and at other localities in that State. We have additional specimens from the Duplin marl of North and South Carolina and from the Yorktown formation of North Carolina and Virginia. As already noted in the Florida paper, the two forms given in the synonymy above may perhaps represent megalospheric and microspheric forms of a single species.

\section{Cibicides americanus (Cushman) \\ Plate 13, Figures 2a-c}

Truncatulina americana Cushman, U. S. Geol. Survey Bull. 676, p. 63 , pl. 20, figs. 2, 3; pl. 21, fig. 1, 1918.

Cibicides americanus Cole and Gillespie, Bull. Am. Paleontology, vol. 15 , No. 57b, p. 14, pl. 4, fig. 4, 1930.

Cushman, Florida Geol. Survey Bull. 4, p. 61, pl. 12, figs. $5 \mathrm{a}-\mathrm{c}, 1930$

Cole and Ponton, Florida Geol. Survey Bull. 5, p. 48, pl. 7, figs. 5, 6, 1930 .

Cushman and Parker, Contr. Cushman Lab. Foram. Research, vol. 7, p. 15, pl. 3, figs. 1a-c, 1931. 
Test planoconvex, dorsal side nearly flat, ventral side slightly convex, periphery subacute; chambers numerous, 8 to 10 in the adult whorl, rather rapidly increasing in size; sutures distinct, slightly limbate on the dorsal side, especially in the earlier chambers, depressed on the ventral side; wall smooth, finely perforate; aperture peripheral and extending onto the dorsal side, with a slight lip. Diameter up to $0.75 \mathrm{~mm}$.

This is a common species in the Miocene and Oligocene of the Coastal Plain region of the United States and also occurs in the late Tertiary of California, Panama, and northern South America.

A reexamination of some of the specimens referred to this species in Bulletin 676 shows that they are the young stage of $C$. concentricus. We have specimens from the Duplin marl of North and South Carolina and the Yorktown formation of North Carolina and Virginia.

\section{Cibicides concentricus (Cushman)}

Plate 13, Figures $3 a-c$

Truncatulina concentrica Cushman, U. S. Geol. Survey Bull. 676, p. 64, pl. 21, fig. 3, 1918.

Cibicides concentricus Cushman, Florida Geol. Survey Bull. 4, p. 61 , pl. 12, figs. $4 a-c, 1930$.

Cushman and Ponton, Florida Geol. Survey Bull. 9, p. 101, 1932.

Test nearly planoconvex, dorsal side nearly flat, ventral side convex, periphery subcarinate; chambers distinct, 7 to 9 in the adult whorl, the inner end on the dorsal side with a definite proximal portion, fusing with adjacent ones to form a concentric band about the middle, and more or less separated by a series of depressions; sutures deep on the ventral side, slightly limbate and flush on the dorsal side; wall smooth, finely perforate; aperture largely dorsal with a thin lip. Diameter up to $1.00 \mathrm{~mm}$.

This is one of the most common species in the Choctawhatchee formation of Florida, from which it was originally described. It occurred in most of the many stations in Florida, and we have it from nearly all of our stations to the north, in the Duplin marl of North and South Carolina, the Yorktown formation of North Carolina and Virginia, and the Calvert formation of Maryland. It is also now known from the Recent material off the coast of Florida and is probably widely distributed in the present West Indian region but in extremely warm or shallow water.

Cibicides lobatulus (Walker and Jacob) var. ornatus (Cushman) Plate 13, Figures 4a-c

Truncatulina lobatula (Walker and Jacob) var. ornata Cushman, U. S. Geol. Survey Bull. 676, p. 61, pl. 18, figs. 1, 2, 1918.

Cibicides lobatula (Walker and Jacob) var. ornata Cushman, Florida Geol. Survey Bull. 4, p. 62, 1930.

Test differing from the typical form in the ornamentation, especially the well-developed bands outlining the chambers on the dorsal side.
This rather unsatisfactory form, which was described from Coes Mill, Liberty County, Fla., from the Choctawhatchee formation, has only one other record-that from Walton County, Fla. We have specimens which may possibly belong to this form from the Yorktown formation of Virginia, and from the Calvert and Choptank formations of Maryland.

Genus DYOCIBICIDES Cushman and Valentine, 1930

Dyocibicides biserialis Cushman and Valentine

Plate 13, Figures 5a-c

Dyocibicides biserialis Cushman and Valentine, Stanford Univ. Dept. Geology Contr., vol. 1, p. 31, pl. 10, figs. 1, 2, 1930.

Cushman, Florida Geol. Survey Bull. 4, p. 62, pl. 12, figs. 6a, b, 1930.

Cushman and Ponton, Florida Geol. Survey Bull. 9, p. 102, 1932.

Test fairly large, the early portion close coiled, later in a spreading biserial series of planoconvex chambers, the dorsal, attached side, flattened; 7 or 8 chambers in the last whorl, chambers not inflated but becoming inflated in the biserial portion and greatly enlarging; sutures in the early coiled part, limbate and not depressed, in the biserial portion continuing the limbate character on the dorsal side but becoming deeply depressed ventrally; wall distinctly perforate; aperture in the early coiled portion peripheral or slightly dorsal, in the uncoiled portion an elongate slit at the outer edge of the chamber at the line of attachment, often elliptical, with a slightly raised lip. Length up to $1.25 \mathrm{~mm}$.

This species was originally described from Recent material off the Florida coast and occurs also in the late Tertiary of that region. It has proved to be fairly common in the Choctawhatchee and Shoal River formations of Florida, occurring at numerous stations, but is very rare in the Chipola and absent from the Oak Grove. The only added localities we have are from the Duplin marl of North Carolina and the Choptank formation of Maryland. This species is also rather widely distributed in the present western Atlantic.

\section{Family PLANORBULINIDAE}

Genus ACERVULINA Schultze, 1854

Acervulina cf. A. inhaerens Schultze

Plate 13, Figures 6, 7

A few incomplete specimens were recorded from the Choctawhatchee formation of Leon County, Fla. ${ }^{12}$ We have figured two specimens apparently belonging to this species from the Duplin marl of North Carolina. Similar forms are common in shallow water of the general West Indian region.

12 Cushman, J. A., Florida Geol. Survey Bull. 4, p. 63, 1930. 



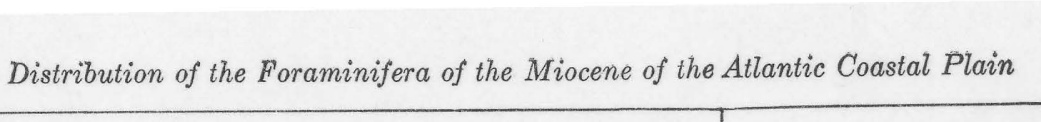

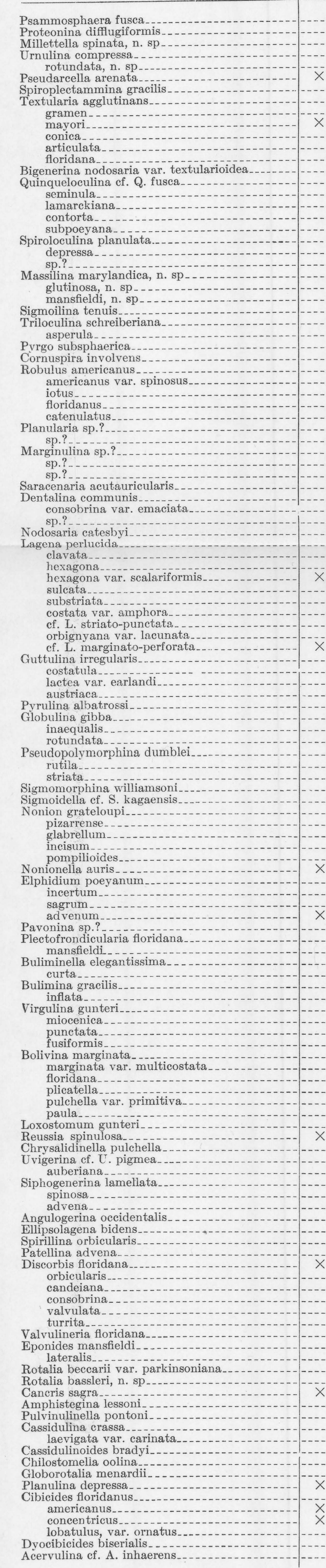

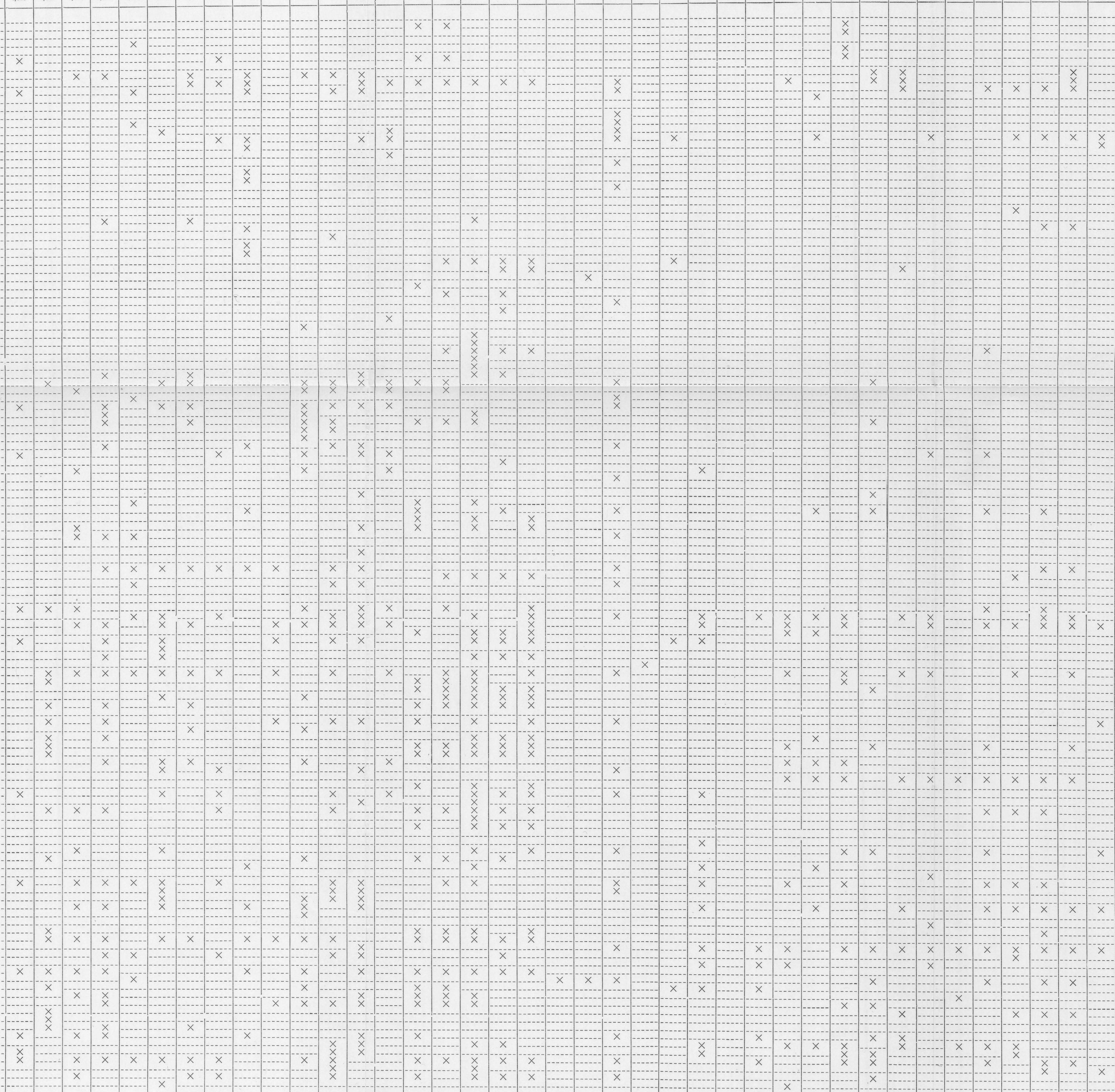




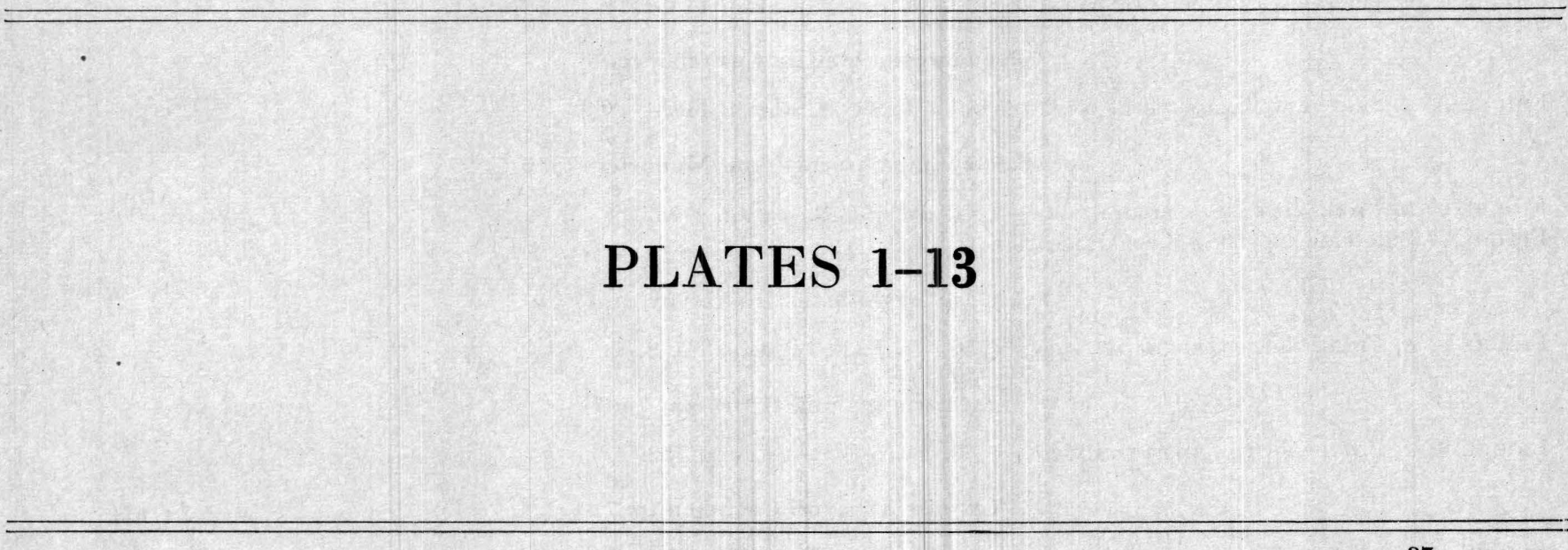




\section{PLATE 1}

Psammosphaera fusca F. E. Schultze(?) (p. 5)

Figure 1. a, b, Opposite sides, $\times 50$. U.S.G.S. station $1 / 750$.

Proteonina difflugiformis (H. B. Brady) (?) (p. 5)

FIGURe 2. a, Front view; b, apertural view, $\times 130$. U.S.G.S. station 11831.

Millettella spinata Cushman and Cahill, n. sp. (p. 5)

Figure 3. a, Front view; b, opposite side; c, apertural view, $\times 200$. U.S.G.S. station 11831 .

Urnulina rotundata Cushman and Cahill, n. sp. (p. 6)

Figure 4. a, Side view; b, apertural view, $\times 130$. U.S.G.S. station 11831.

Pseudarcella arenata Cushman (p. 6)

Figure 5. a, Side view; b, apertural view, $\times 130$. U.S.G.S. station 11831

\section{Spiroplectammina gracilis (von Muenster) (p. 6)}

Figure 6. a, Front view; b, apertural view, $\times 50$. U.S.G.S. station $1 / 752$.

Figdre 7. Side view, $\times 50$. U.S.G.S. station $1 / 752$.

\section{Textularia agglutinans D'Orbigny (p. 7)}

Figure 8. a, Front view, b, apertural view, $\times 50$. U.S.G.S. station $1 / 752$.

\section{Textularia gramen D'Orbigny (p. 7)}

Figure 9. a, Front view; b, apertural view, $\times$ 50. U.S.G.S. station 1/752.

Textularia mayori Cushman (p. 7)

FIgURe 10. a, Front view; b, apertural view, $\times 50$. U.S.G.S. station 1/205.

Textularia conica D'Orbigny (p. 8)

Figure 11. a, Front view; b, apertural view, $\times 70$. U.S.G.S. station 11824.

Textularia articulata D'Orbigny (p. 8)

Figure 12. a, Front view; b, apertural view, $\times 60$. Chesapeake Beach, $\mathrm{Md}$.

Textularia floridana Cushman (p. 8)

FIGURE 13. a, Front view; b, apertural view, $\times 90$. U.S.G.S. station 1/950.

Bigenerina nodosaria D'Orbigny var. textularioidea (Goës) (p. 8)

Figure 14. Side view, $\times 80$. U.S.G.S. station $1 / 946$. 


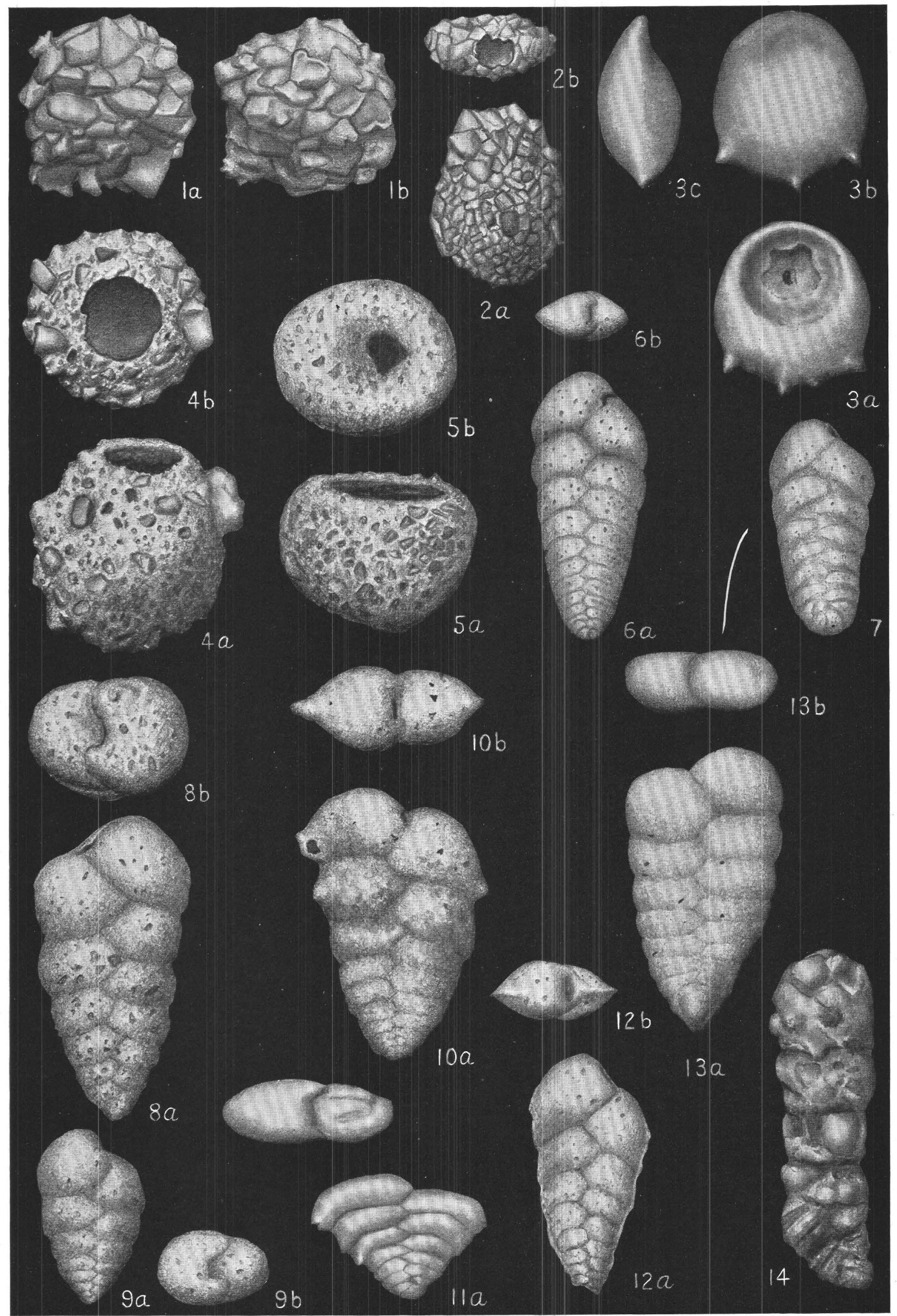

$136785^{\circ}-33-4$

MIOCENE FORAMINIFERA OF THE ATLANTIC COASTAL PLAIN 


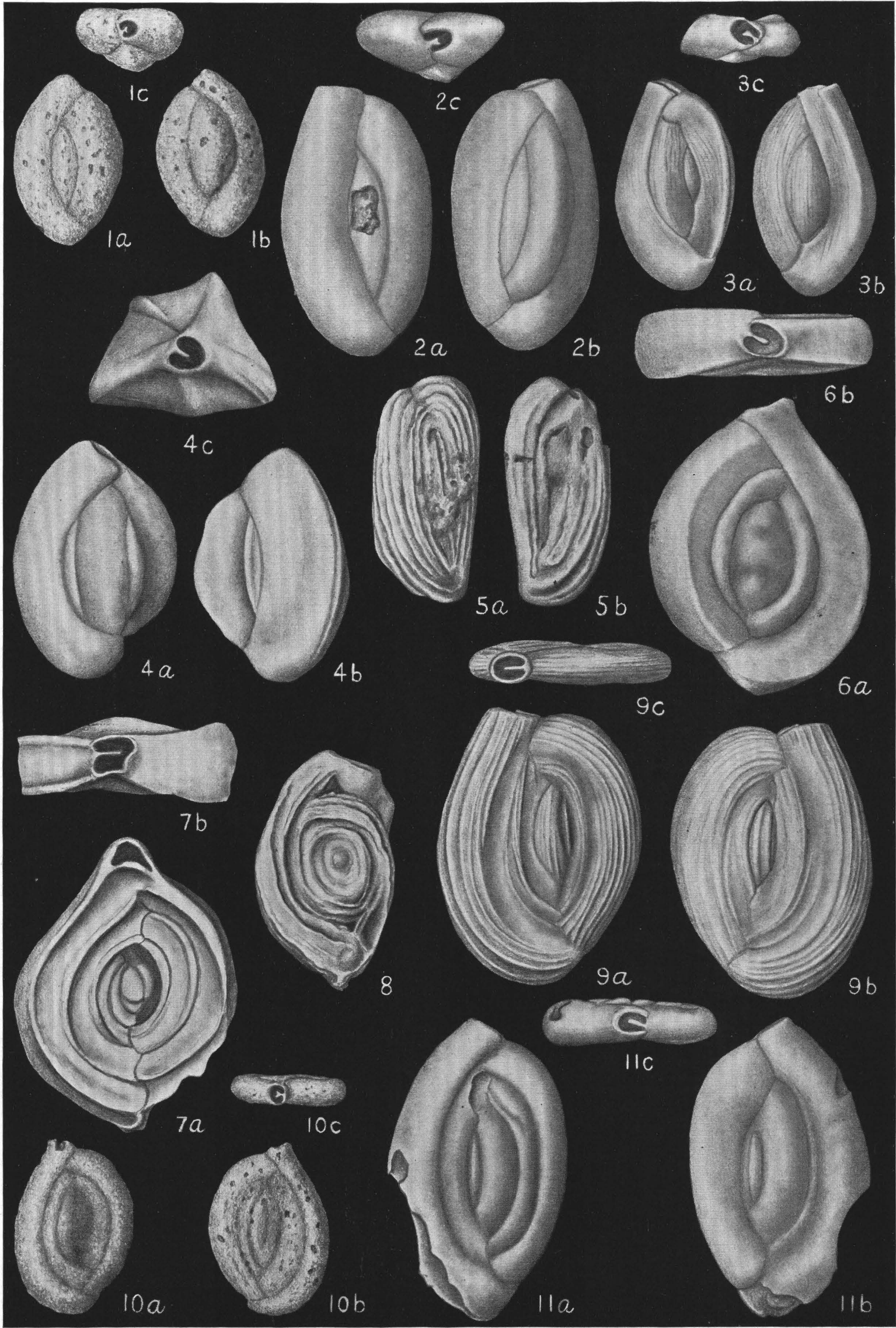

MIOCENE FORAMINIFERA OF THE ATLANTIC COASTAL PLAIN 


\section{PLATE 2}

Quinqueloculina cf. Q. fusca H. B. Brady (p. 9)

Figure 1. a, b, Opposite sides; c. apertural view, $\times$ 50. $\quad$ U.S.G.S. station 9619 .

Quinqueloculina seminula (Linné) (p. 9)

Figdre 2. a, b, Opposite sides; c, apertural view, $\times$ 50. U.S.G.S. station 1/234.

Quinqueloculina contorta D'Orbigny (p. 9)

Figure 3. a, b, Opposite sides; c, apertural view, $\times$ 50. U.S.G.S. station 1/752.

Quinqueloculina lamarckiana D'Orbigny (p. 9)

Figdre 4. a. b, Opposite sides; c, apertural view, $\times$ 65. U.S.G.S. station 1/967.

Quinqueloculina subpoeyana Cushman (p. 10)

Figure 5. a, b, Opposite sides, $\times 100$. U.S.G.S. station 1/955.

Spiroloculina planulata (Lamarck) (p. 10)

Figure 6. a, Front view; b, apertural view, $\times 100$. U.S.G.S. station 1/967.

Spiroloculina depressa D'Orbigny (p. 10)

Figdre 7. a, Front view; b, apertural view, $\times 60$. Jackson Bluff, Leon County, Fla.

Spiroloculina sp. ? (p. 10)

Figdre 8. Side view, $\times 100$. U.S.G.S. station $1 / 955$.

Massilina marylandica Cushman and Cahill, n. sp. (p. 10)

Figdre 9. a, b, Opposite sides; c, apertural view, $\times$ 50. U.S.G.S. station 1/903.

Massilina glutinosa Cushman and Cahill, n. sp. (p. 10)

Figure 10. a, b, Opposite sides; c, apertural view, $\times$ 50. U.S.G.S. station 1/752.

Massilina mansfieldi Cushman and Cahill, n. sp. (p. 11)

Figure 11. a, b, Opposite sides; c, apertural view, $\times$ 50. U.S.G.S. station 1/193. 


\section{PLATE 3}

Sigmoilina tenuis (Czjzek) ( p. 11)

Figure 1. a, b, Opposite sides; c, apertural view, $\times 100$. U.S.G.S. station $1 / 947$.

\section{Triloculina schreiberiana D'Orbigny (p. 11)}

Figure 2. a, b, Opposite sides; c, apertural view, $\times 65$. Coes Mill, Liberty County, Fla.

Triloculina asperula Cushman (p. 11)

Figure 3. Side view, $\times 100$. Coes Mill, Liberty County, Fla.

Pyrgo subsphaerica (D’Orbigny) (p. 11)

Figdre 4. a, Front view; b, side view; c, apertural view, $\times 50$. Jackson Bluff, Leon County, Fla.

Cornuspira involvens (Reuss) (p. 12)

Figdre 5. Side view, $\times 100$. U.S.G.S. station $1 / 967$.

Robulus americanus (Cushman) (p. 12)

Figure 6. a, Side view; b, apertural view, $\times 60$. U.S.G.S. station 1/948.

Robulus americanus (Cushman), var. spinosus (Cushman) (p. 12)

Figure 7. a, Side view; b, apertural view, $\times 60$. U.S.G.S. station 1/948.

40 


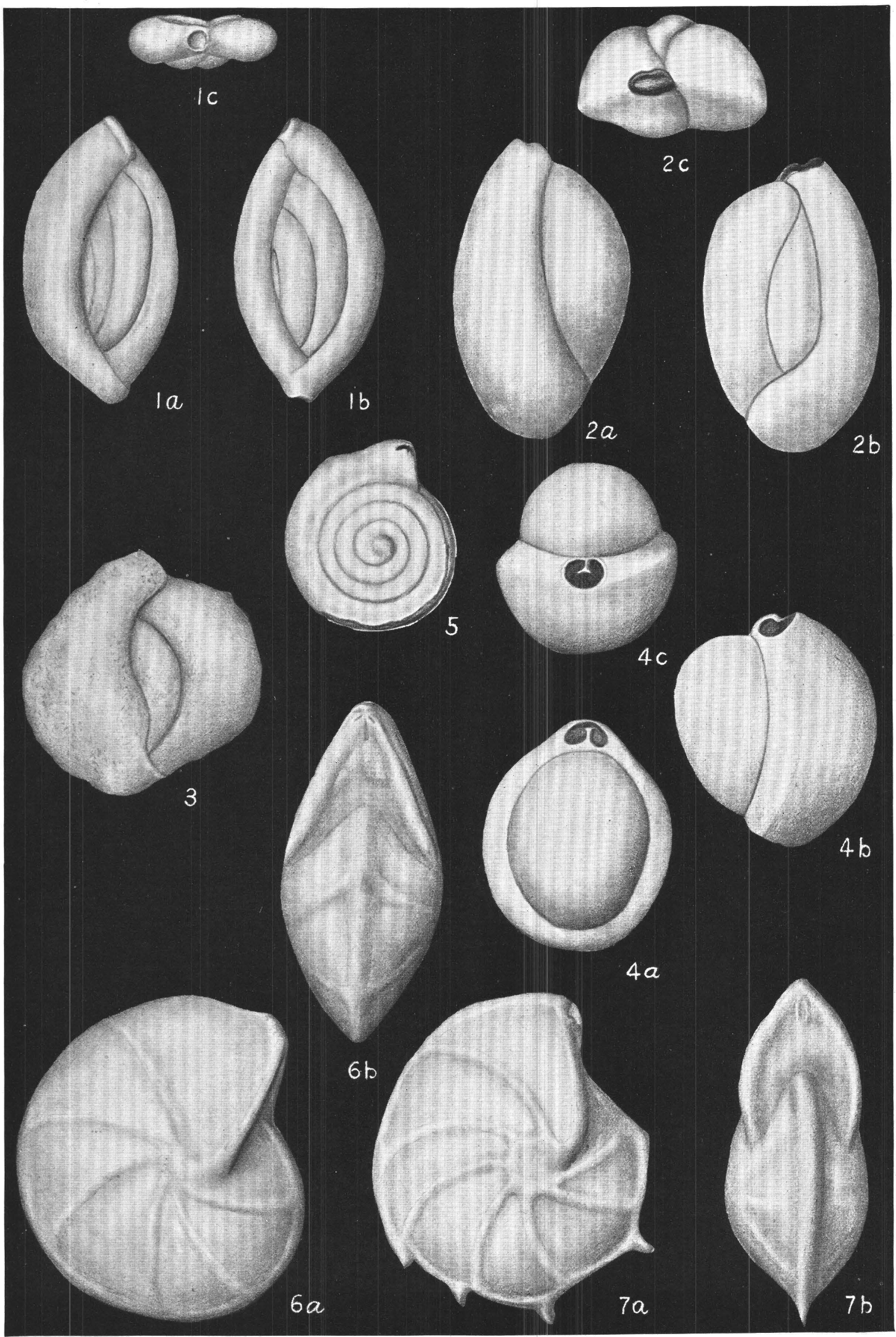

MIOCENE FORAMINIFERA OF THE ATLANTIC COASTAL PLAIN 


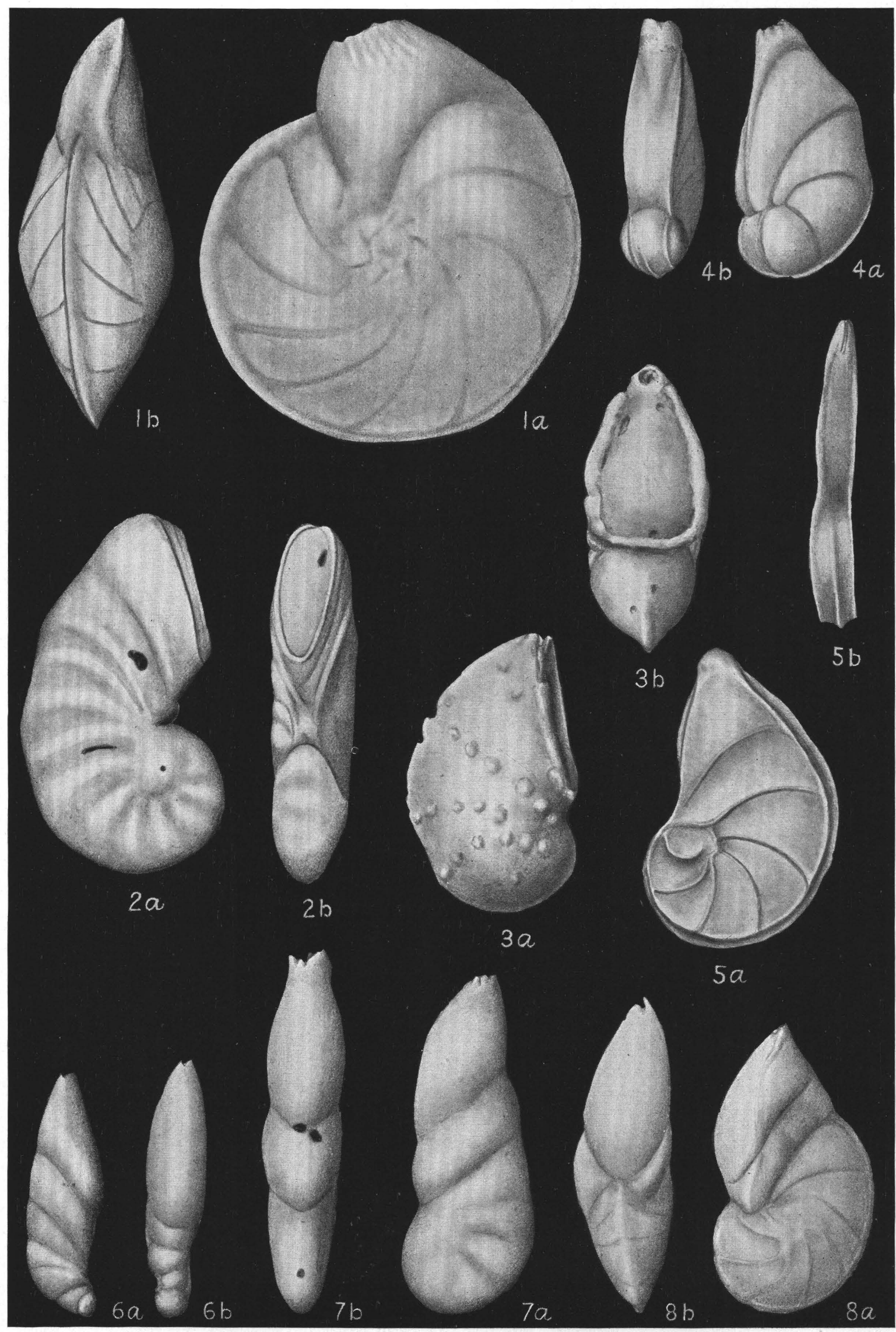




\section{PLATE 4}

Robulus iotus (Cushman) (p. 12)

Figure 1. a, Side view; b, peripheral view, $\times 45$. U.S.G.S. station 1/706.

Robulus floridanus (Cushman) (p. 12)

Figure 2. a, Side view; b, peripheral view, $\times$ 50. 1 mile south of Red Bay, Walton County, Fla.

Robulus catenulatus (Cushman) (p. 13)

Figure 3. a, Side view; b, peripheral view, $\times 90$. U.S.G.S. station 1/673.

Planularia sp. ? (p. 13)

Figure 4. a, Side view; b, peripheral view, $\times 90$. U.S.G.S. station $1 / 655$.

Planularia sp. ? (p. 13)

Figure 5. a, Side view; b, peripheral view, $\times$ 90. U.S.G.S. station 1/948.

Marginulina sp. ? (p. 13)

Figure 6. a, Side view; b, peripheral view, $\times$ 90. U.S.G.S. station 1/962.

\section{Marginulina dubia Neugeboren (p. 13)}

Figure 7. a, Side view; b, peripheral view, $\times 65$. U.S.G.S. station 1/956.

Marginulina sp. ? (p. 13)

Figure 8. a, Side view; b, peripheral view, $\times 65$. U.S.G.S. station 1/947. 


\section{PLATE 5}

\section{Saracenaria acutauricularis (Fichtel and Moll) (p. 13)}

Figure 1. a, Side view; b, peripheral view, $\times 65$. U.S.G.S. station $1 / 947$.

\section{Dentalina communis D'Orbigny (p. 14)}

Figure 2. Side view, $\times 65$. U.S.G.S. station $1 / 947$.

Dentalina consobrina D'Orbigny var. emaciata Reuss (p. 14)

FIgURe 3. Side view, $\times 65$. U.S.G.S. station $1 / 947$.

$$
\text { Dentalina sp. ? (p. 14) }
$$

Figure 4. Side view, $\times 90$. U.S.G.S. station $1 / 947$.

\section{Nodosaria catesbyi D’Orbigny .(p. 14)}

Figure 5. Side view, $\times 90$. U.S.G.S. station $1 / 965$.

Lagena perlucida (Montagu) (p. 15)

Figure 6. a, Side view; b, apertural view, $\times 130$. U.S.G.S. station $1 / 222$.

Lagena clavata (D'Orbigny) (p. 15)

FIgURE 7. a, Side view; b, apertural view, $\times 130$. U.S.G.S. station $1 / 752$.

Lagena hexagona (Williamson) (p. 15)

Figure 8. a, Side view; b, apertural view, $\times 125$. U.S.G.S. station 1/946.

Lagena hexagona (Williamson) var. scalariformis (Williamson) (p. 15)

Figure 9. a, Side view; b, apertural view, $\times 100$. U.S.G.S. station 1/958.

Lagena sulcata (Walker and Jacob) (p. 16)

Figure 10. Side view, $\times 100$. U.S.G.S. station $1 / 960$.

Lagena substriata Williamson (p. 16)

Figure 11. a, Side view; b, apertural view, $\times 130$. U.S.G.S. station 1/903.

Lagena orbignyana (Seguenza), var. lacunata Burrows and Holland (p. 16)

Figure 12. a, Side view; b, apertural view, $\times 100$. U.S.G.S. station $1 / 958$.

Lagena cf. L. striato-punctata Parker and Jones (p. 16)

Figure 13. Side view. $\times 100$. U.S.G.S. station $1 / 956$.

Lagena costata (Williamson) var. amphora Reuss (p. 16)

Figure 14. Side view, $\times 90$. Chesapeake Beach, Md.

Lagena cf. L. marginato-perforata (Seguenza) (p. 17)

Figure 15. a, Side view; b, apertural view, $\times 130$. U.S.G.S. station $1 / 234$. 


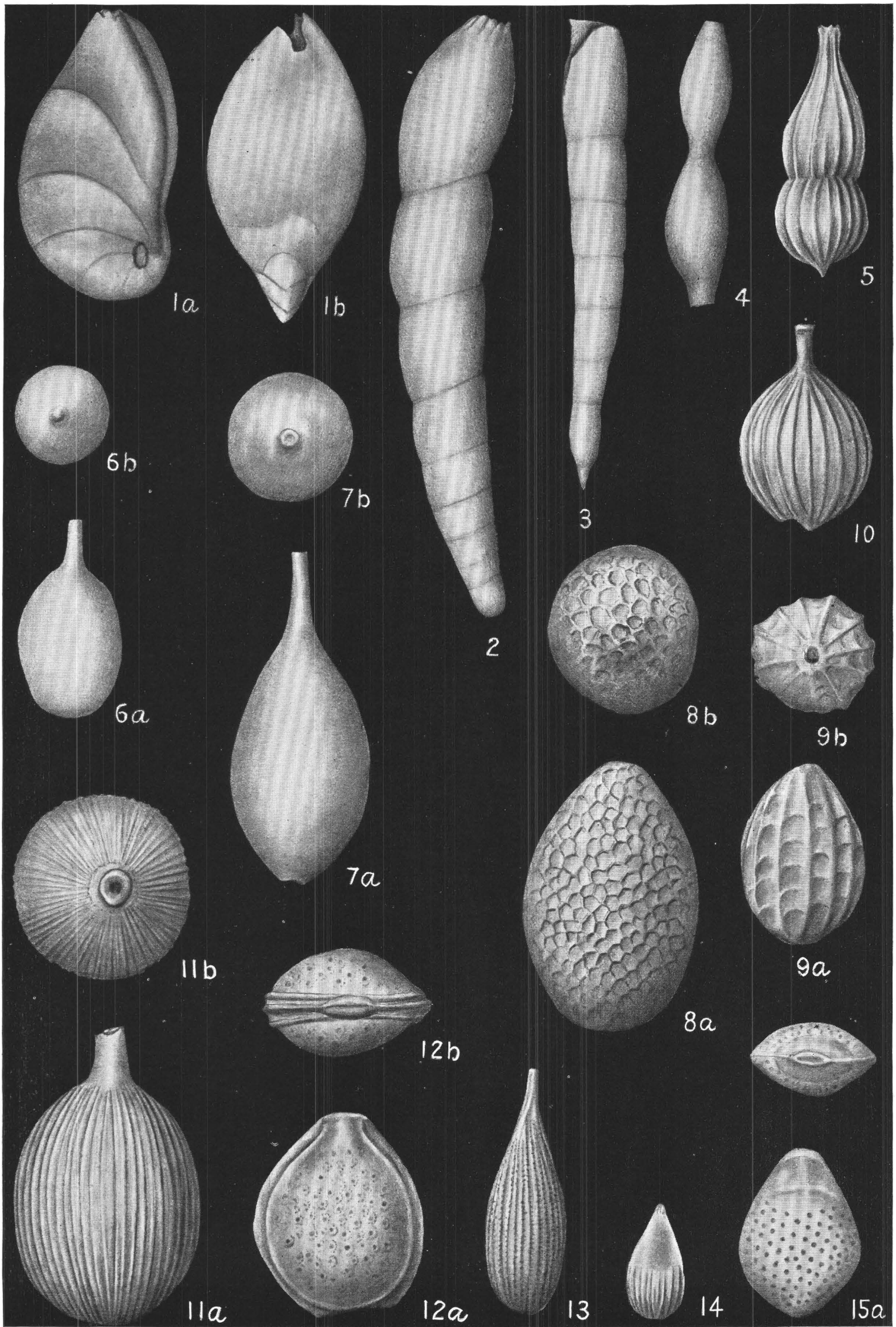

MIOCENE FORAMINIFERA OF THE ATLANTIC COASTAL PLAIN 

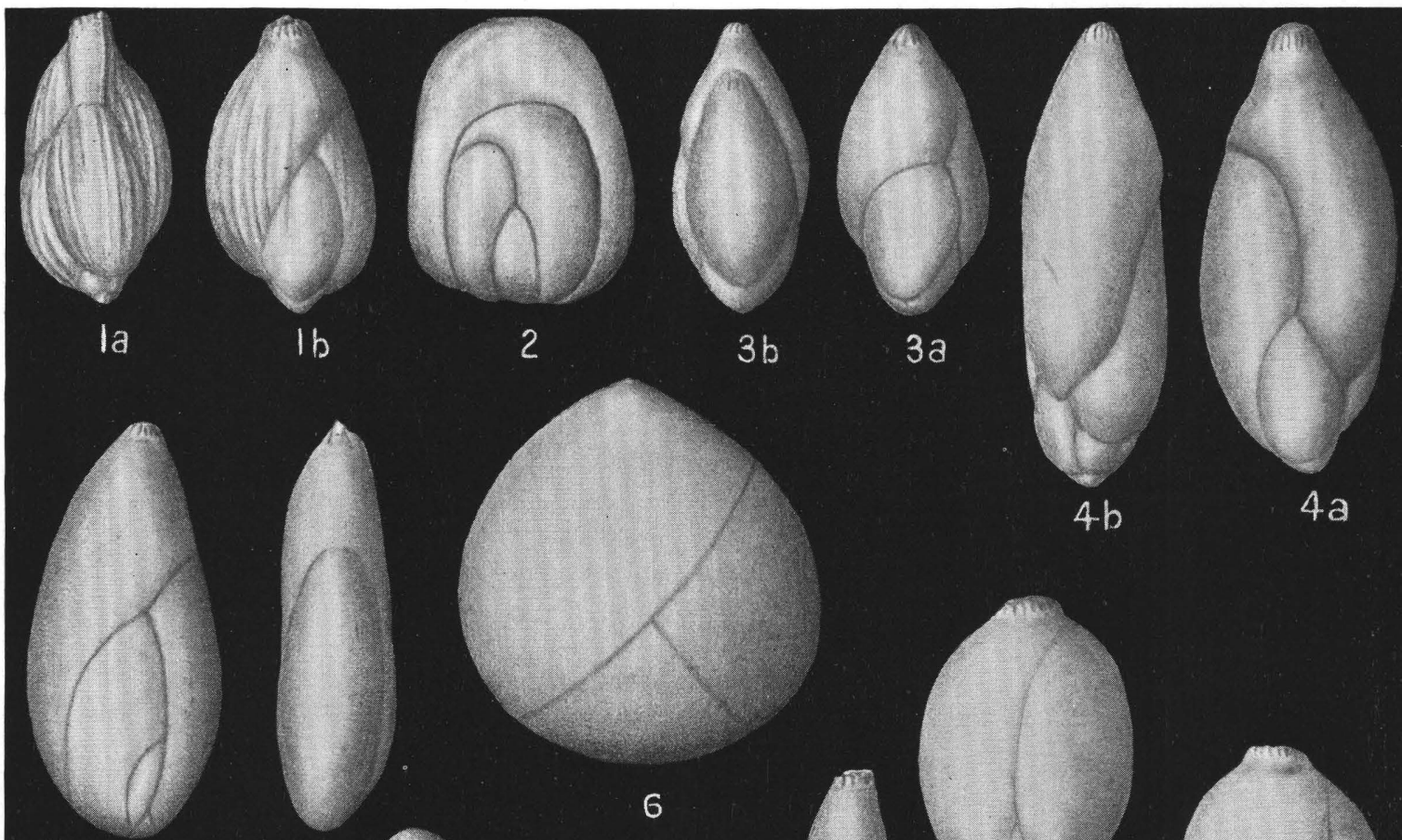


\section{PLATE 6}

Guttulina costatula Galloway and Wissler (p. 17)

Figure 1. a, b, Opposite sides, $\times 70$. Mayesville, S. C.

Guttulina lactea (Montagu) var. earlandi Cushman and Ozawa (p. 17)

FIgURE 2. Side view, $\times 100$. U.S.G.S. station $1 / 955$.

\section{Guttulina austriaca D'Orbigny (p. 17)}

Figure 3. a, Front view; b, side view, $\times 70$. U.S.G.S. station $1 / 543$.

Figure 4. a, Front view; b, side view, $\times 70$. U.S.G.S. station $1 / 543$.

Pyrulina albatrossi Cushman and Ozawa (p. 18)

Figure 5. a, Front view; b, side view, $\times 70$. U.S.G.S. station $1 / 752$.

Globulina gibba D'Orbigny (p. 18)

Figure 6. Front view, $\times 90$. U.S.G.S. station $1 / 947$.

\section{Globulina inaequalis Reuss (p. 18)}

Figure 7. a, b, Opposite sides, $\times 90$. U.S.G.S. station 11824 .

FIGURE 8. a, b, Opposite sides, $\times 70$. U.S.G.S. station 1/201.

\section{Globulina rotundata (Bornemann) (p. 18)}

Figure 9. Front view, $\times 90$. U.S.G.S. station $1 / 947$.

Pseudopolymorphina dumblei (Cushman and Applin) (p. 19)

Figure 10. a, Front view; b, side view, $\times 90$. U.S.G.S. station 1/543.

Pseudopolymorphina rutila (Cushman) (p. 19)

Figure 11. Front view, $\times 65$. U.S.G.S. station $1 / 954$.

\section{Pseudopolymorphina striata (Bagg) (p. 19)}

Figure 12. Front view, $\times 50$. Plum Point, Md.

Figure 13. a, Front view; b, side view, $\times$ 50. Plum Point, Md.

\section{Sigmomorphina williamsoni (Terquem) (p. 19)}

Figure 14. Front view, $\times 90$. U.S.G.S. station $1 / 961$.

Sigmoidella cf. S. kagaensis Cushman and Ozawa (p. 19)

Figure 15. a, Front view; b, side view, $\times$ 50. Plum Point, Md. 


\section{PLATE 7}

\section{Nonion grateloupi (D'Orbigny) (p. 20)}

FIGURE 1. a, Side view; b, peripheral view, $\times 90$. U.S.G.S. station 1/205.

\section{Nonion pizarrense Berry (p. 20)}

Figure 2. a, Side view; b, peripheral view, $\times$ 50. U.S.G.S. station $1 / 903$.

Nonion glabrellum Cushman (p. 20)

Figure 3. a, Side view; $b$, peripheral view, $\times 100$. U.S.G.S. station 1/958.

Nonion incisum (Cushman) (p. 20)

FIgUre 4. a, Side view; b, peripheral view, $\times 50$. U. S.G.S. station $1 / 752$.

\section{Nonion pompilioides (Fichtel and Moll) (p. 21)}

Figure 5. a, Side view; b, peripheral view, $\times 65$. Centerville, $M d$.

Nonionella auris (D'Orbigny) (p. 21)

Figure 6. a, Síde view; b, peripheral view, $\times 70$. U.S.G.S. station 1/903.

Elphidium poeyanum (D'Orbigny) (p. 21)

Figure 7. a, Side view; b, peripheral view, $\times 70$. Mayesville, S. C.

Elphidium incertum (Williamson) (p. 21)

Figure 8. Side view, $\times 70$. U.S.G.S. station 11820 .

Elphidium sagrum (D'Orbigny) (p. 22)

Figure 9. a, Side view; b, peripheral view, $\times 70$. U.S.G.S. station 11820.

Elphidium advenum (Cushman) (p. 22)

Figure 10. a, Side view; b, peripheral view, $\times 70$. Mayesville, S. C.

Plectofrondicularia floridana Cushman (p. 22)

Figure 11. Front view, $\times 70$. U.S.G.S. station $1 / 950$.

Plectofrondicularia mansfieldi Cushman and Ponton (p. 23)

Figure 12. a, Front view; b, side view, $\times$ 70. Old Frasier farm, NW. 1/4 SE. 1/4 sec. 18 . T. 2 N., R. 19 S., Florida.

Buliminella elegantissima (D'Orbigny) (p. 23)

Figure 13. Front view, $\times 90$. U.S.G.S. station $1 / 234$.

FIgURe 14. Side view, $\times 90$. U.S.G.S. station $1 / 234$.

Buliminella curta Cushman (p. 23)

Figure 15 . Front view, $\times 90$. U.S.G.S. station $1 / 682$.

Bulimina gracilis Cushman (p. 24)

Figure 16. a, Front view; b, side view, $\times 90$. U.S.G.S. station $1 / 543$. 


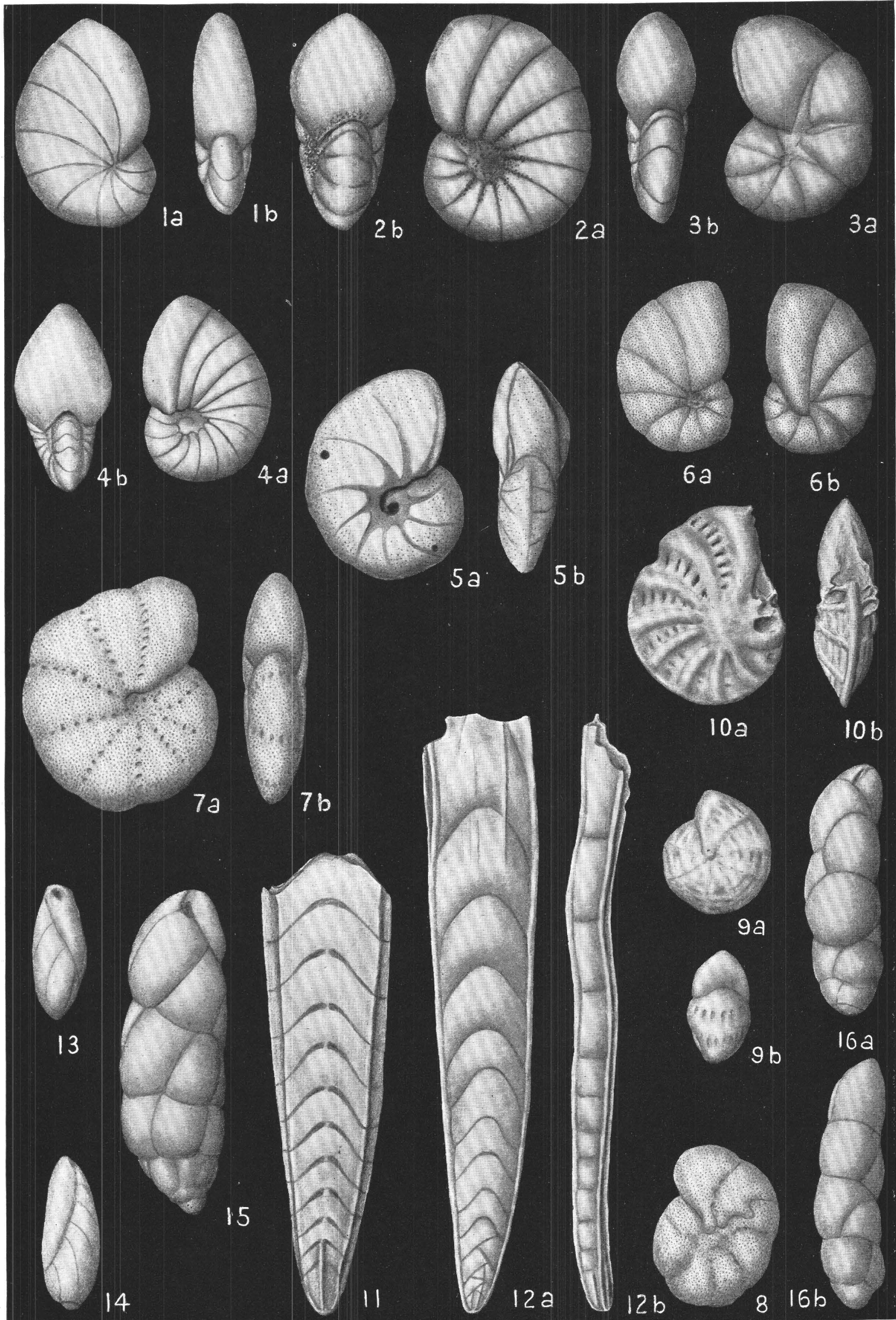

MIOCENE FORAMINIFERA OF THE ATLANTIC COASTAL PLAIN 
, 


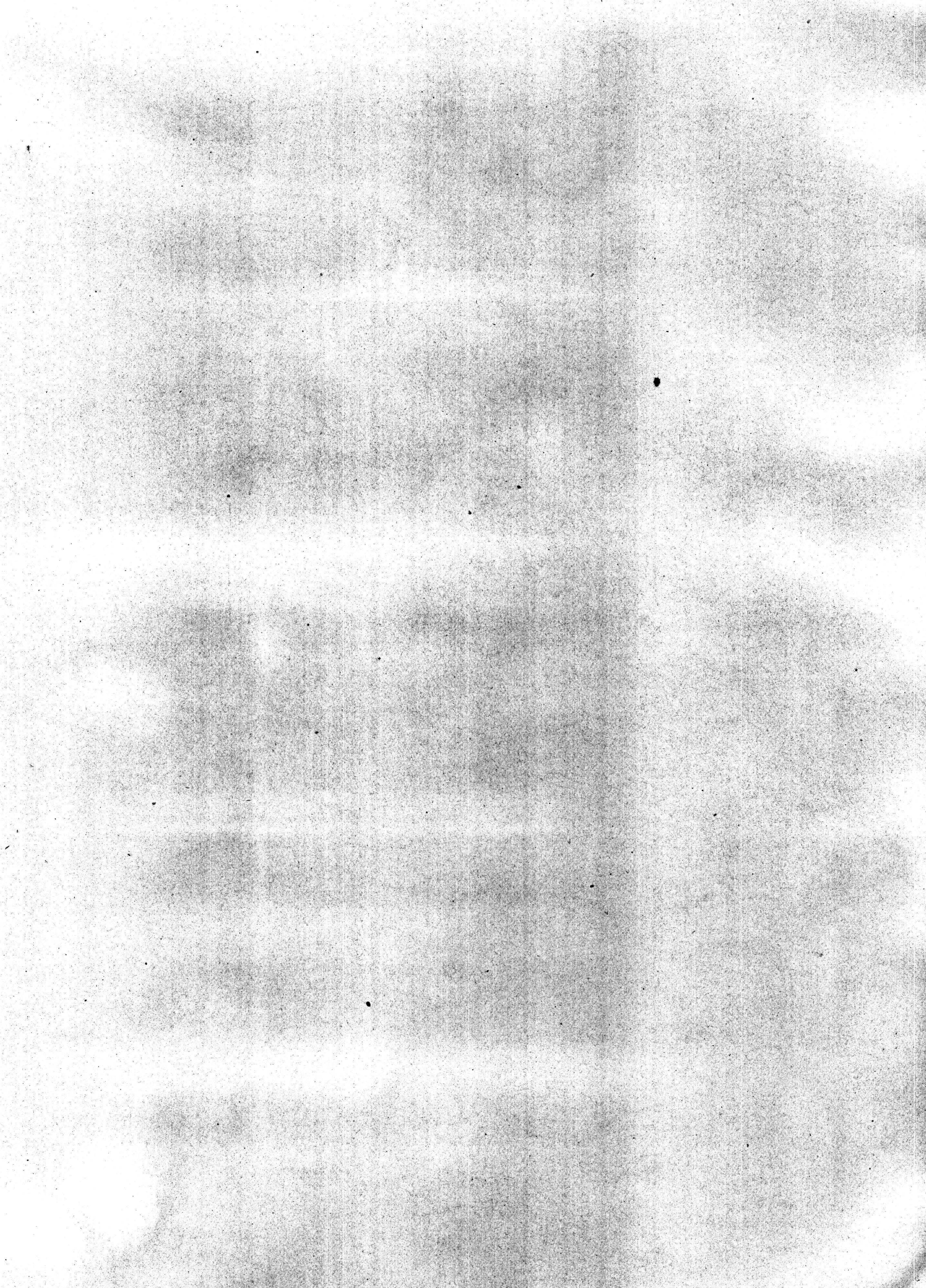




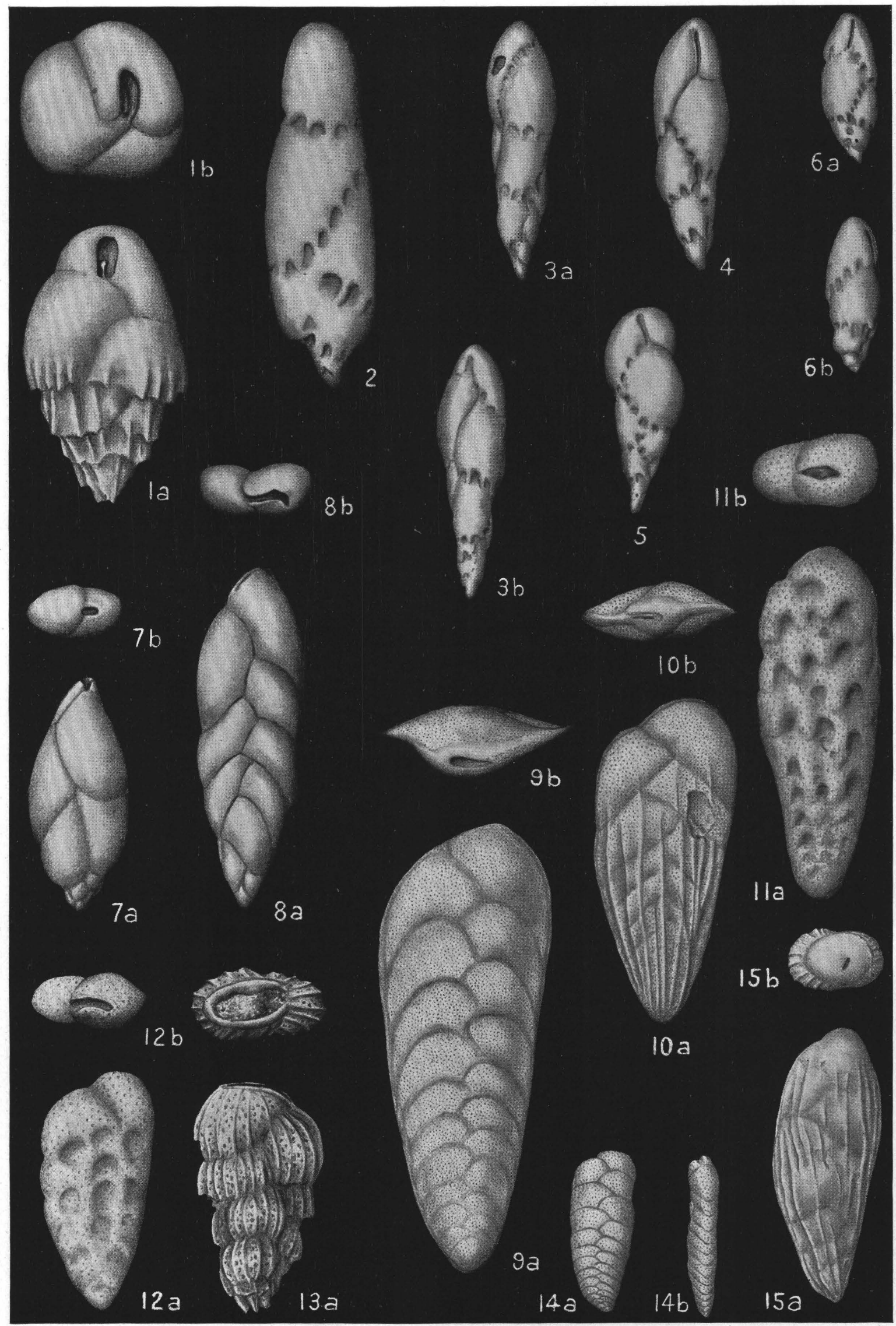

MIOCENE FORAMINIFERA OF THE ATLANTIC COASTAL PLAIN 


\section{PLATE 8}

Bulimina inflata Seguenza (p. 24)

Figure 1. a, Front view; b, apertural view, $\times 70$. U.S.G.S. station $1 / 748$.

Virgulina (Virgulinella) gunteri Cushman (p. 24)

Figure 2. Front view, $\times 60$. U.S.G.S. station $1 / 963$.

Virgulina (Virgulinella) miocenica Cushman and Ponton (p. 24)

Figure 3. a, b, Opposite sides, $\times 50$. U.S.G.S. station 1/903.

Figure 4. Front view, $\times 50$. U.S.G.S. station $1 / 903$.

Figure 5. Front view, $\times$ 50. U.S.G.S. station $1 / 903$.

Figure 6. a, b, Opposite sides, $\times$ 50. U.S.G.S. station 1/903.

Virgulina fusiformis Cushman (p. 25)

Figure 7. a, Front view; b, apertural view, $\times 125$. U. S. G. S. station 1/956.

Virgulina punctata D'Orbigny (p. 25)

Figure 8. a, Front view; b, apertural view, $\times 90$. U.S.G.S. station 1/682.

Bolivina marginata Cushman (p. 25)

Figure 9. a, Front view; b, apertural view, $\times 90$. U.S.G.S. station 1/950.

Bolivina marginata Cushman, var. multicostata Cushman (p. 25)

FIgURE 10. a, Front view; b, apertural view, $\times 100$. U.S.G.S. station 1/950.

Bolivina floridana Cushman (p. 26)

Figure 11. a, Front view; b, apertural view, $\times 70$. U.S.G.S. station $1 / 950$.

Bolivina plicatella Cushman (p. 26)

Figure 12. a, Front view; b, apertural view, $\times 125$. U.S.G.S. station 1/962.

Bolivina pulchella D'Orbigny var. primitiva Cushman (p. 26)

FigURe 13. Front view; b, apertural view, $\times 100$. U.S.G.S. station 1/961.

Bolivina paula Cushman and Cahill (p. 26)

Figure 14. a, Front view; b, side view, $\times$ 90. U.S.G.S. station 1/188.

Loxostomum gunteri Cushman (p. 26)

Figure 15. a, Front view; b, apertural view, $\times 90$. U.S.G.S. station 1/950. 


\section{PLATE 9}

\section{Reussia spinulosa (Reuss) (p. 27)}

Figure 1. a, Front view; b, apertural view, $\times 90$. U.S.G.S. station $1 / 947$.

\section{Chrysalidinella pulchella (Cushman) (p. 27)}

Figure 2. a, Front view; b, apertural view, $\times 100$. U.S.G.S. station 1/947.

Uvigerina auberiana D'Orbigny (p. 27)

Figure 3. Front view, $\times 100$. U.S.G.S. station $1 / 947$.

Siphogenerina lamellata Cushman (p. 28)

Figure 4. Front view, $\times 60$. U.S.G.S. station $1 / 948$.

\section{Siphogenerina spinosa Bagg (p. 28)}

Figure 5. Front view copied from type figure, $\times$ 38.5. Jones Wharf, Md.

Figure 6. Front view, $\times 50$. Drawn from type specimen.

Siphogenerina advena Cushman (p. 28)

Figure 7. a, Front view; b, side view, $\times 90$. Mayesville, S. C.

Angulogerina occidentalis (Cushman) (p. 28)

Figure 8. a, Front view; b, side view, $\times 90$. U.S.G.S. station 11831.

Ellipsolagena bidens Cushman (p. 28)

Figure 9. a, Front view; b, apertural view, $\times 125$. U.S.G.S. station $1 / 682$.

Spirillina orbicularis Bagg (p. 29)

Figdre 10. a, Dorsal view; b, ventral view, $\times$ 90. U.S.G.S. station 11824 .

Patellina advena Cushman (p. 29)

Figure 11. a, Dorsal view; b, ventral view, $\times 160$. U.S.G.S. station 11836.

Discorbis floridana Cushman (p. 29)

Figure 12. a, Dorsal view; $b$, ventral view; $c$, peripheral view, $\times 70$. U.S.G.S. station 11820.

Figure 13. a, Dorsal view; b, ventral view; c, peripheral view, $X 90$. U.S.G.S. station 1/958. 


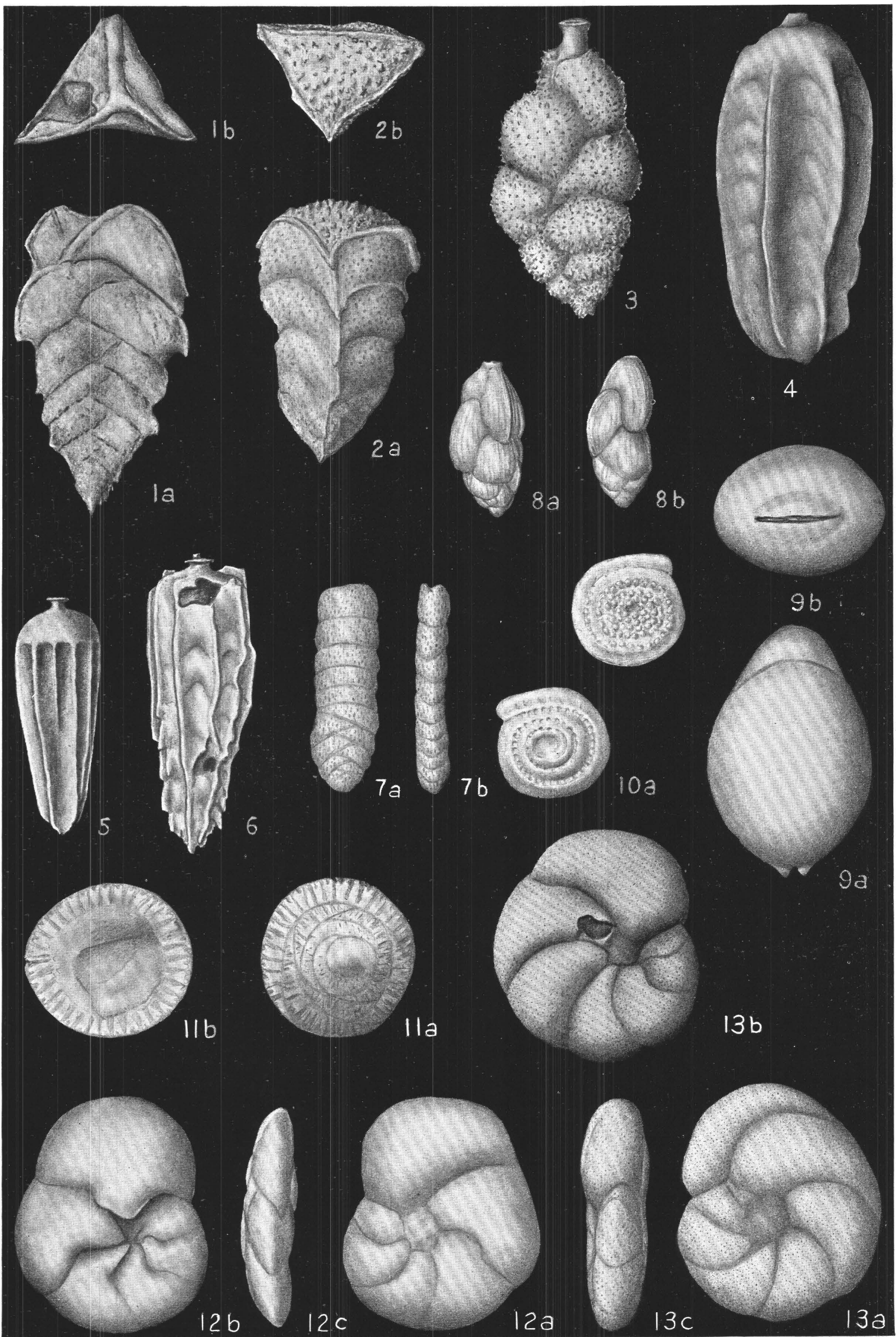

$136785^{\circ}-33-5$ 


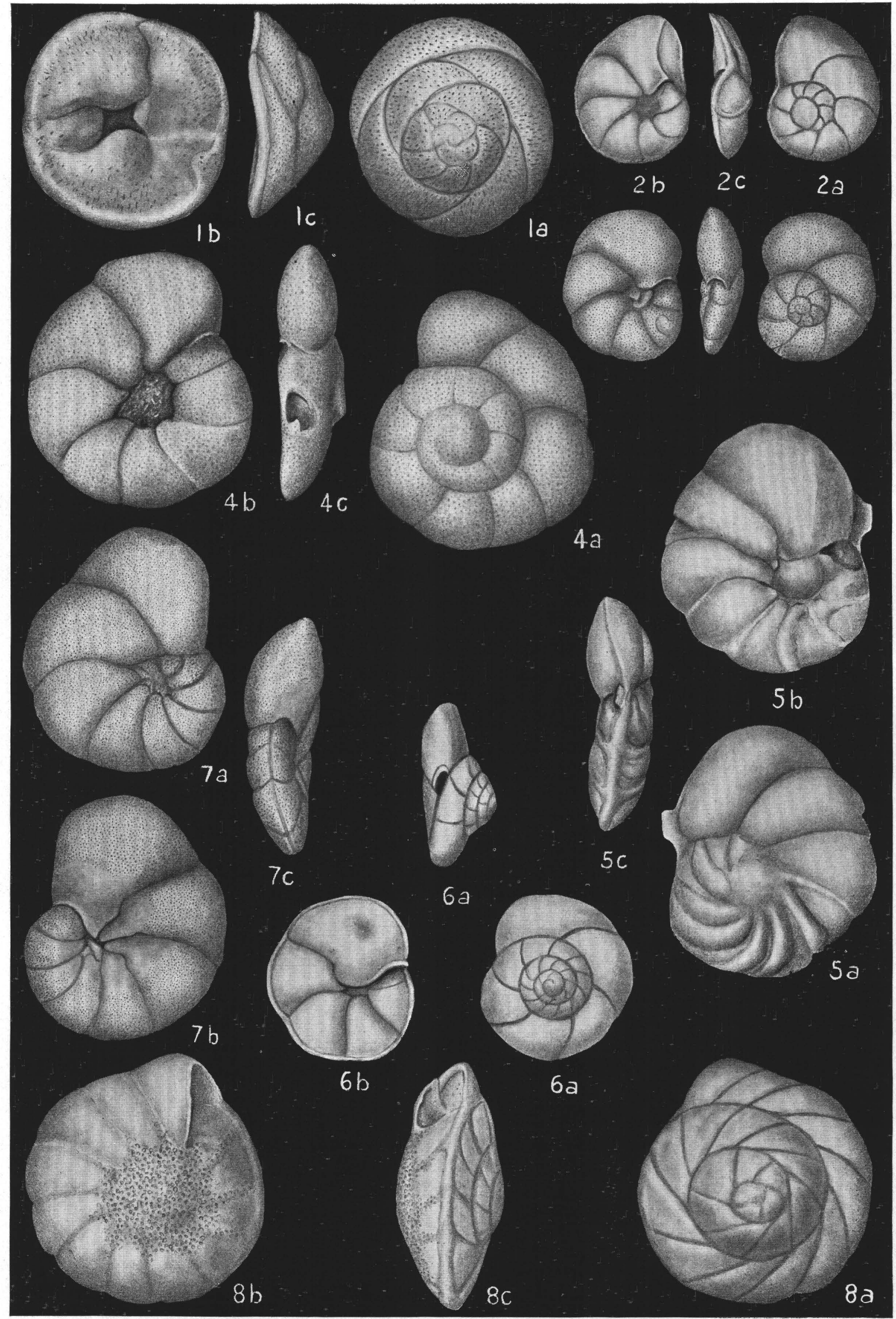

MIOCENE FORAMINIFERA OF THE ATLANTIC COASTAL PLAIN 


\section{PLATE 10}

Discorbis orbicularis (Terquem) (p. 29)

Figure 1. a, Dorsal view; b, ventral view; c, peripheral view, $\times 90$. U.S.G.S. station 1/955.

\section{Discorbis valvulata (D'Orbigny) (p. 30)}

Figure 2. a, Dorsal view; $b$, ventral view; c, peripheral view, $\times 90$. U.S.G.S. station 1/543.

Figure 5. a, Dorsal view; b, ventral view; c, peripheral view, $\times 90$. Chesapeake Beach, Md

Discorbis candeiana (D'Orbigny) (p. 29)

Figure 3. a, Dorsal view; b, ventral view; c, peripheral view, $\times 90$. U.S.G.S. station $1^{\prime} 470 a$. (These figures, unnumbered on the plate, appear just below $2 \mathrm{a}, 2 \mathrm{~b}$, and $2 \mathrm{c}$.)

\section{Discorbis consobrina (D’Orbigny) ( p. 30)}

FIGURE 4. a, Dorsal view; b, ventral view; c, peripheral view, $X$ 175. U.S.G.S. station 1/954.

\section{Discorbis turrita Cushman (p. 30)}

Figure 6. a, Dorsal view; b, ventral view; c, peripheral view, $\times 60$. Suffolk, Va.

\section{Valvulineria floridana Cushman (p. 30)}

Figure 7. a, Dorsal view; b, ventral view; c, peripheral view, $\times 70$. Plum Point, $M d$.

\section{Eponides mansfieldi Cushman (p. 31)}

Figure 8. a, Dorsal view; $b$, ventral view; c, peripheral view, $\times$ 70. U.S.G.S. station 1/903. 


\section{PLATE 11}

Eponides lateralis (Terquem) (p. 31)

Figure 1. a, Dorsal view; b, ventral view; $c$, peripheral view, $\times 70$. U.S.G.S. station $1 / 543$.

Rotalia bassleri Cushman and Cahill, n. sp. (p. 32)

Figure 2. a, Dorsal view; b, ventral view; c, peripheral view, $\times 90$. Chesapeake Beach, Md.

Rotalia beccarii (Linné) var. parkinsoniana (D'Orbigny) (p. 31)

Figure 3. a, Dorsal view; b, ventral view; c, peripheral view, $\times 70$. Mayesville, S. C.

Cancris sagra (D'Orbigny) (p. 32)

Figure 4. a, Dorsal view; b, ventral view; c, peripheral view, $\times 70$. U.S.G.S. station $1 / 188$

Figure 5. a, Dorsal view; $b$, ventral view; c, peripheral view, $\times 70$. U.S.G.S. station $1 / 188$.

Amphistegina lessonii D’Orbigny (p. 32)

Figure 6. a, Dorsal view; $b$, ventral view; c, peripheral view, $\times 60$. U.S.G.S. station 1/706. 48 


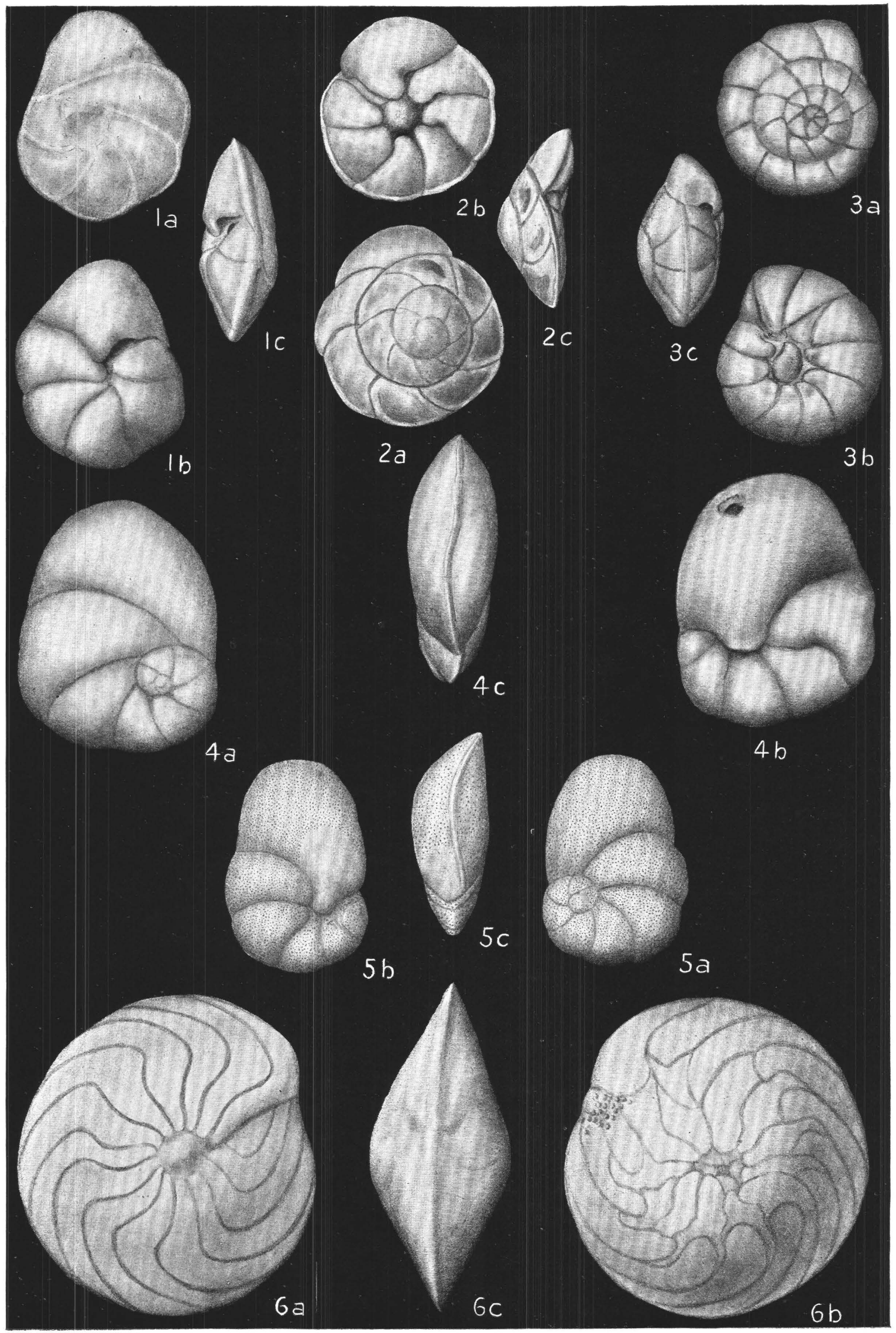

MIOCENE FORAMINIFERA OF THE ATLANTIC COASTAL PLAIN 

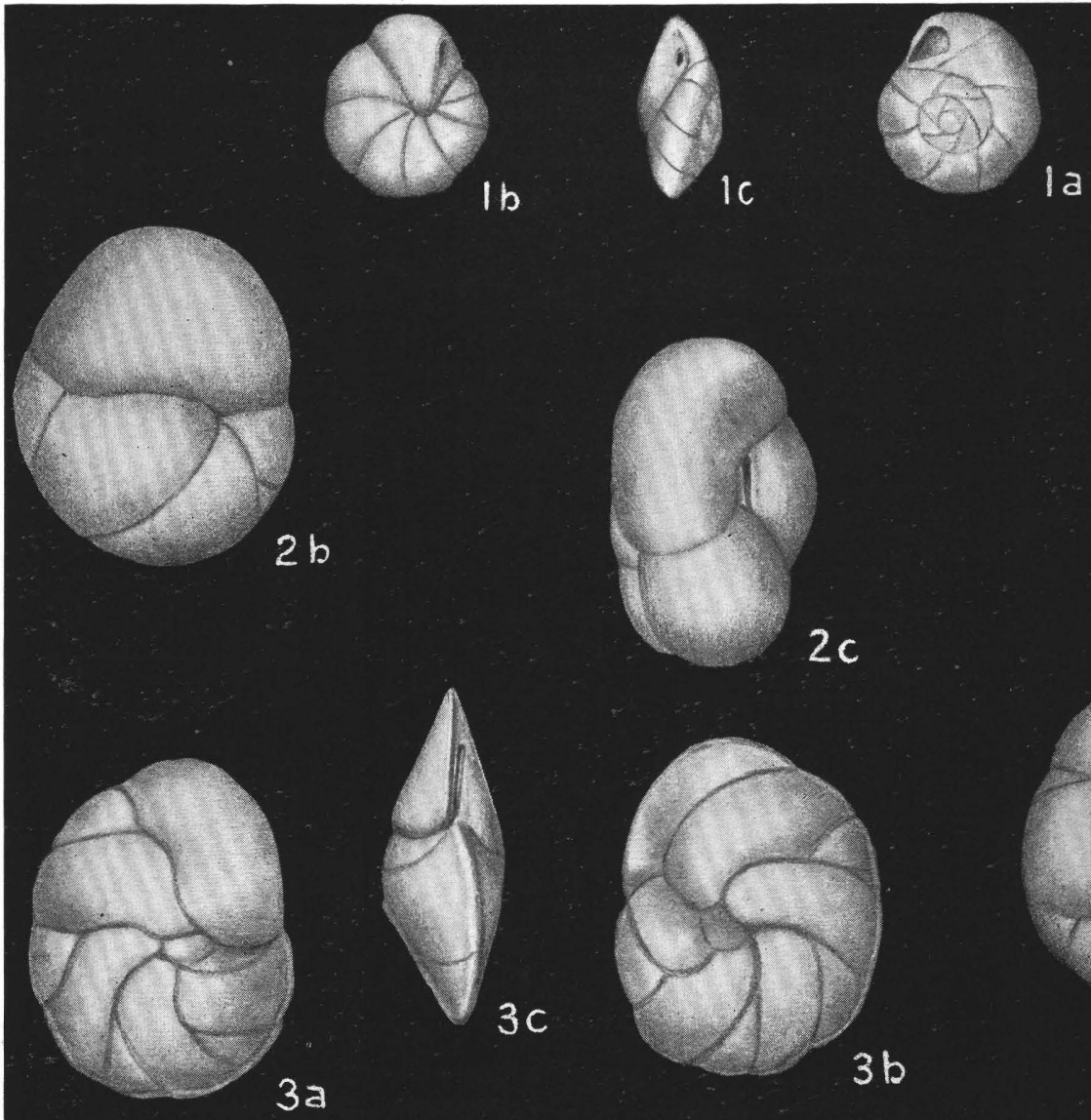

b
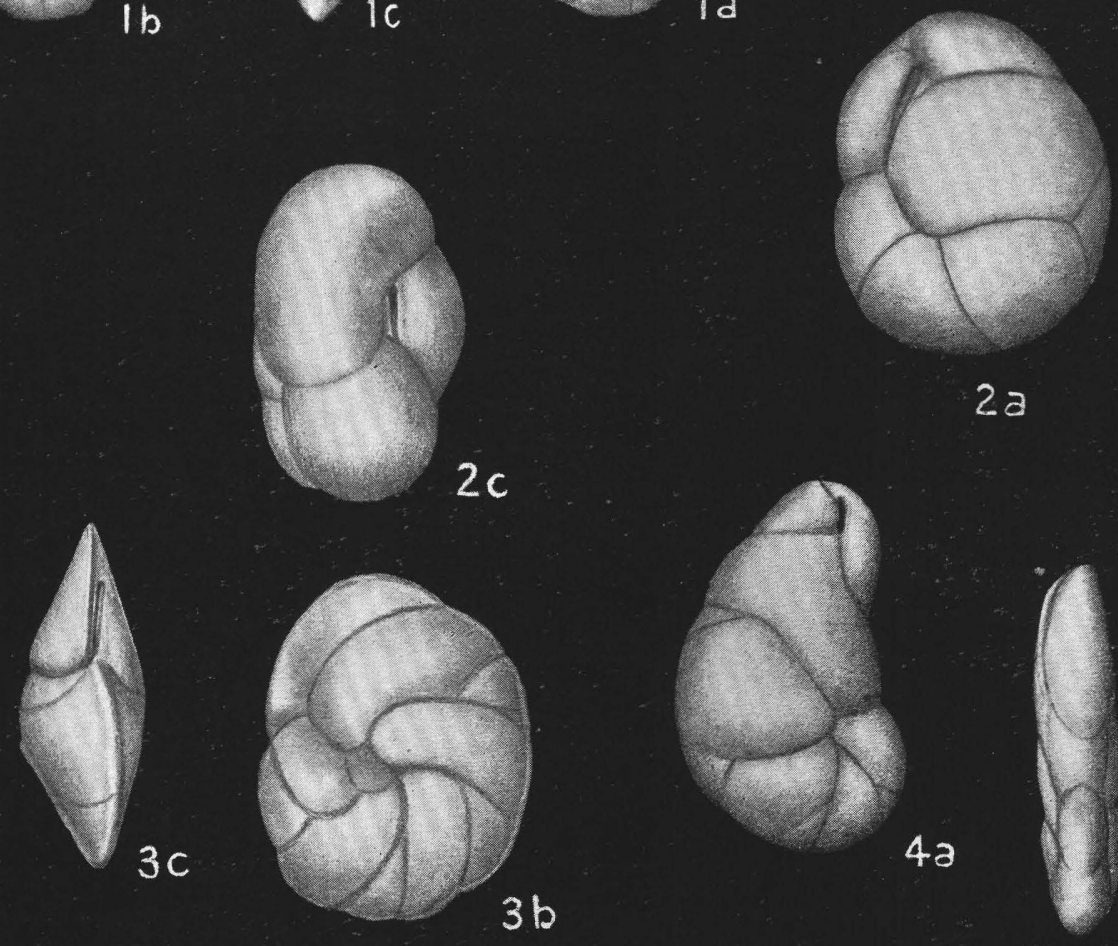

$2 a$

$3 a$
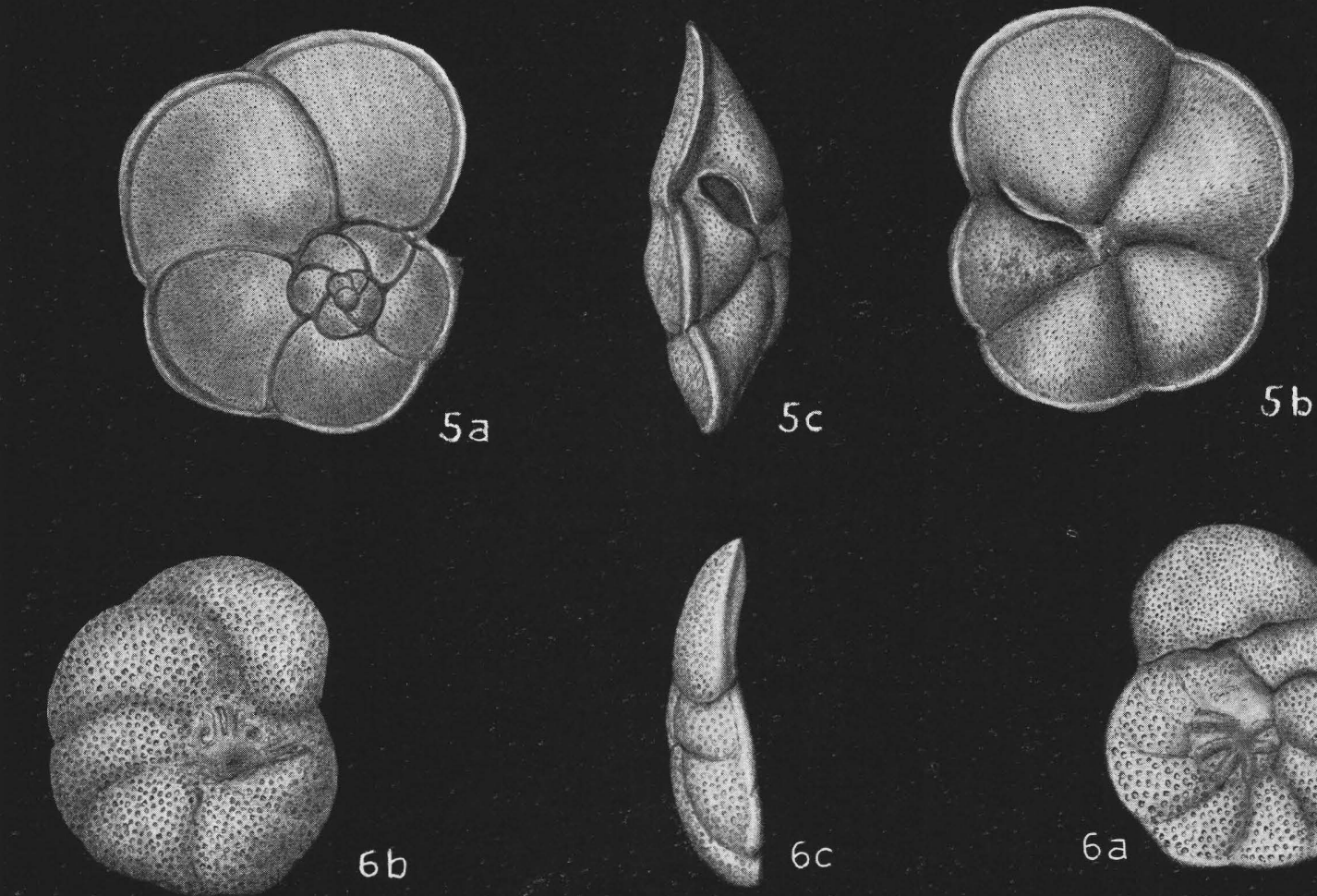

$6 c$
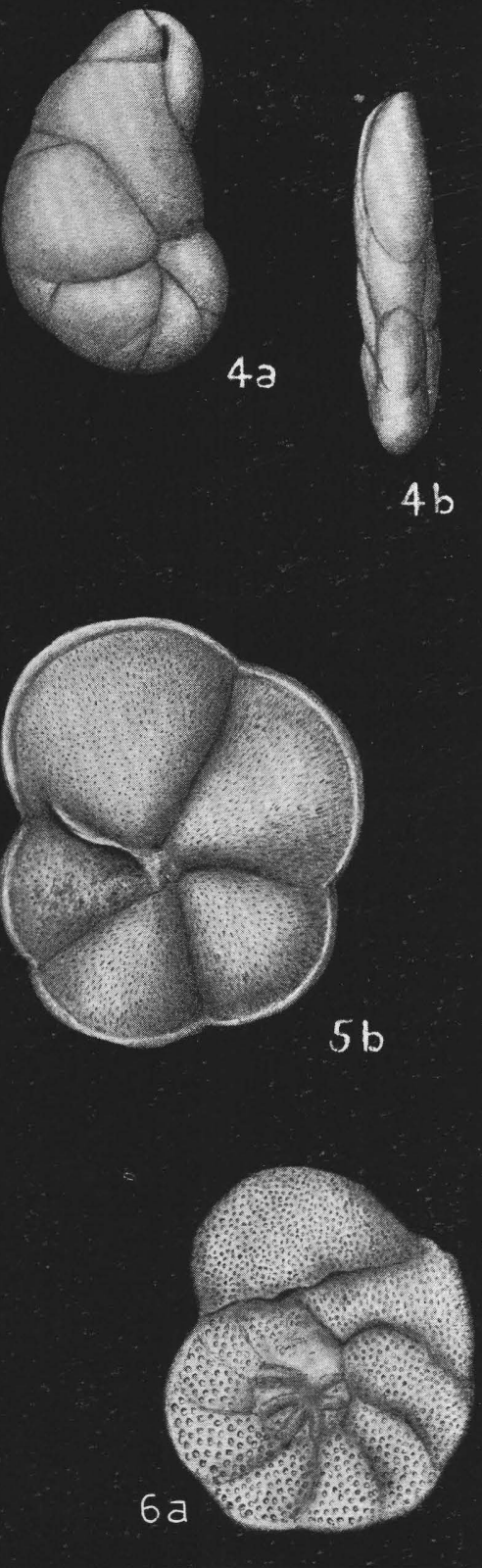

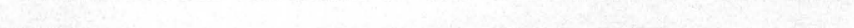




\section{PLATE 12}

Pulvinulinella pontoni Cushman (p. 32)

Figure 1. a, Dorsal view; b, ventral view; c, peripheral view, $\times 200$. U.S.G.S. station 11837 .

\section{Cassidulina crassa D’Orbigny (p. 32)}

Figure 2. a, Dorsal view; b, ventral view; c, peripheral view, $\times 200$. U.S.G,S. station 1/470a.

Cassidulina laevigata D'Orbigny var. carinata Cushman (p. 32)

Figure 3. a, Dorsal view; b, ventral view; c, peripheral view, $\times 90$. U.S.G.S. station 1/903.

Cassidulinoides bradyi (Norman) (p. 33)

Figure 4. a, Front view; b, side view, $\times 100$. U.S.G.S. station $1 / 954$.

Globorotalia menardii (D’Orbigny) (p. 34)

Figure 5. a, Dorsal view; b, ventral view; c, peripheral view, $\times 60$. U.S.G.S. station 1/965.

Planulina depressa (D'Orbigny) (p. 34)

FIgURE 6. a, Dorsal view; b, ventral view; c, peripheral view, $\times$ 50. U.S.G.S. station 11835 . 


\section{PLATE 13}

\section{Cibicides floridanus (Cushman) (p. 34)}

Figure 1. a, Dorsal view; b, ventral view; c, peripheral view, $\times$ 70. U.S.G.S. station 11837.

Cibicides americanus (Cushman) (p. 34)

Figdre 2. a, Dorsal view; b, ventral view; c, peripheral view, $\times 90$. U.S.G.S. station 1/193.

Cibicides concentricus (Cushman) (p. 35)

Figure 3. a, Dorsal view; $b$, ventral view; $c$, peripheral view, $\times 70$. Plum Point, Md.

Cibicides lobatulus (Walker and Jacob) var. ornatus (Cushman) (p. 35)

Figure 4. a, Dorsal view; $b$, ventral view; c, peripheral view, $\times 70$. Plum Point, Md.

\section{Dyocibicides biserialis Cushman and Valentine (p. 35)}

FIgURE 5. a, Dorsal view; b, ventral view; c, peripheral view, $\times 50$. U.S.G.S. station 1/222.

Acervulina cf. A. inhaerens Schultze (p. 35)

FIgURE 6. a, Dorsal view; b, ventral view, $\times 50$. U.S.G.S. station 11820 .

Figure 7. a, Dorsal view; $b$, ventral view, $\times$ 50. U.S.G.S. station 11820 . Young.

50 


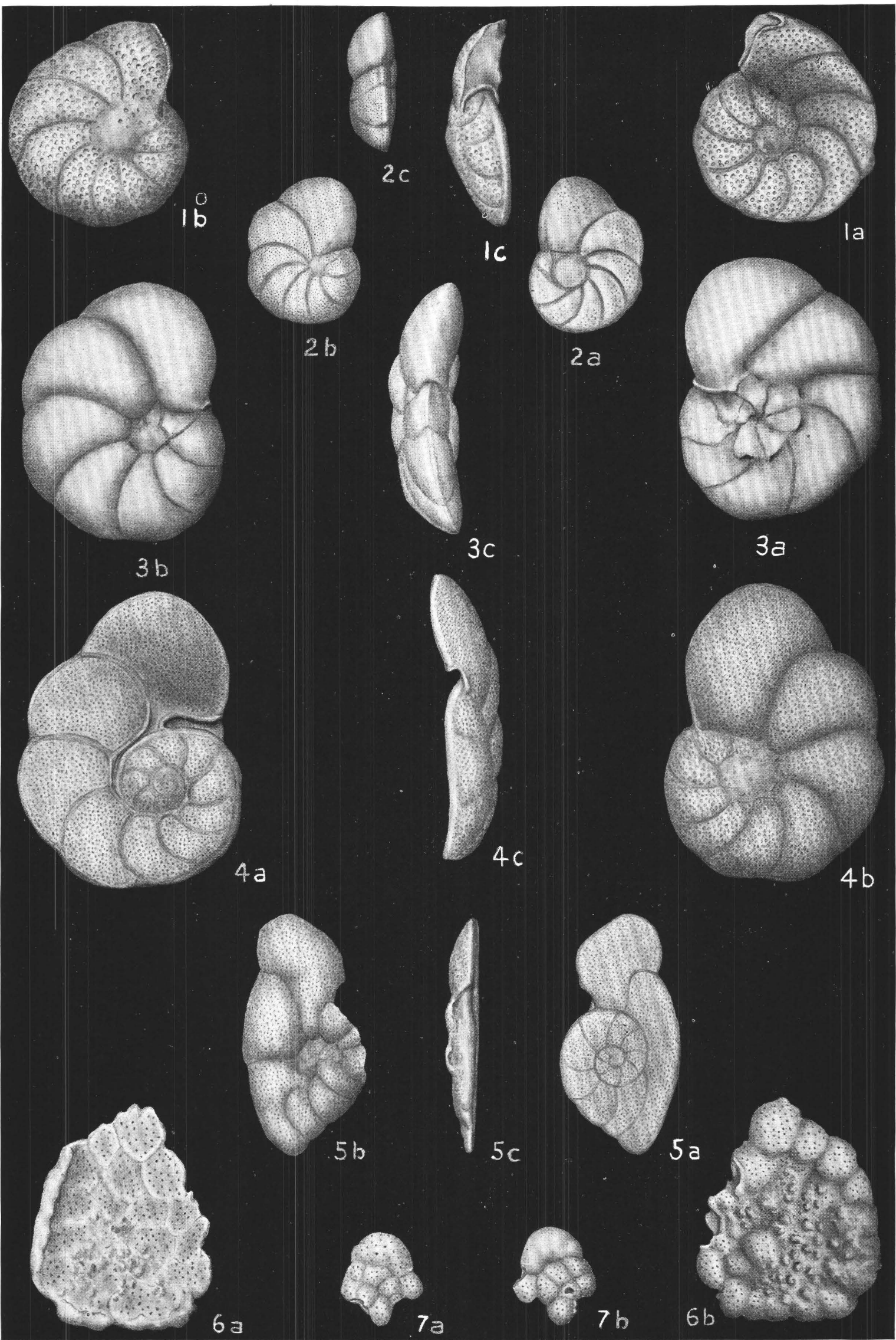

MIOCENE FORAMINIFERA OF THE ATLANTIC COASTAL PLAIN 